$$
\begin{gathered}
\text { UNIVERSIDADE DE SÃO PAULO } \\
\text { ESCOLA DE ENGENHARIA DE SÃO CARLOS } \\
\text { DEPARTAMENTO DE ENGENHARIA MECÂNICA }
\end{gathered}
$$

\title{
ALEXANDRE MARGARIDO
}

Estudo da influência da força de corte da usinagem a verde nas propriedades mecânicas de cerâmicas sinterizadas 
AUTORIZO A REPRODUÇÃO E DIVULGAÇÃO TOTAL OU PARCIAL DESTE TRABALHO, POR QUALQUER MEIO CONVENCIONAL OU ELETRÔNICO, PARA FINS DE ESTUDO E PESQUISA, DESDE QUE CITADA A FONTE.

Ficha catalográfica preparada pela Seção de Tratamento da Informação do Serviço de Biblioteca - EESC/USP

Margarido, Alexandre.

M327e Estudo da influência da força de corte da usinagem a verde nas propriedades mecânicas de cerâmicas sinterizadas. / Alexandre Margarido ; orientador Carlos Alberto Fortulan. São Carlos, 2011.

Dissertação (Mestrado - Programa de Pós-Graduação em Engenharia Mecânica e Área de Concentração em Projeto Mecânico)-- Escola de Engenharia de São Carlos da Universidade de São Paulo, 2011.

1. Usinagem. 2. Usinagem por abrasão. 3. Grinding. 3. Green machining. 4. Ceramic green machining. I. Título. 
Estudo da influência da força de corte da usinagem a verde nas propriedades mecânicas de cerâmicas sinterizadas

Dissertação apresentada à Escola de

Engenharia de São Carlos da Universidade de São Paulo, como parte dos requisitos para a obtenção do título de Mestre em Engenharia Mecânica.

Área de Concentração: Projeto Mecânico Orientador: Prof. Dr. Carlos Alberto Fortulan

São Carlos

2011 

DEDICATÓRIA

Aos meus pais, Narciso e Isaura. 



\section{AGRADECIMENTOS}

Ao Professor Dr. Carlos Alberto Fortulan pela orientação desta pesquisa pelos ensinamentos e dedicação em todas as etapas deste trabalho. Por direcionar-me em diversos momentos com seu conhecimento e agradeço também pela amizade.

Professor Titular Benedito de Moraes Purquerio pela co-orientação, participação, colaboração durante este trabalho, pelos ensinamentos e também pela amizade.

Ao Professor Dr. Jarbas Caiado Castro Neto pelo apoio e motivação para o ingresso a pós-graduação.

À José Carlos Risardi do Laboratório de Processos de Fabricação - EESC - USP, pelo empenho na manufatura de partes do equipamento, pela colaboração em diversos procedimentos desta pesquisa e pela amizade.

Ao técnico Luiz Penazzi do Laboratório de Tribologia e Compósitos, pelo auxílio técnico sempre que necessário.

À Danilo Ramos pelo apoio no desenvolvimento do sistema de aquisição de dados.

À Claudia Cristiane Camilo, Karen Laurenti, Thiago e à Camila Meira pela amizade e colaboração em diversos momentos deste trabalho e pela amizade.

Os autores agradecem ao Conselho Nacional de Desenvolvimento Científico e tecnológico (CNPq) pela concessão do projeto Universal CNPq (479041/2009-1), ao Instituto Nacional de Ciência e Tecnologia (INCT) em Biofabricação - BIOFABRIS (INCTBIOFABRIS) / Bolsa mestrado, CAPES e Bolsa de Iniciação Científica PIBIC 2010. 



\section{RESUMO}

MARGARIDO, A. (2011). Estudo da influência da força de corte da usinagem a verde nas propriedades mecânicas de cerâmicas sinterizadas. Dissertação de Mestrado Escola de Engenharia de São Carlos, Universidade de São Paulo, São Carlos, 2011.

O estudo trata da medição da força de usinagem a verde de corpos de provas cerâmicos e sua correlação com as propriedades mecânicas após a sinterização. A usinagem a verde é empregada em compactos brutos para conferir formatos sem extremo compromisso com precisão dimensional ou para obter uma pré-forma antes da usinagem de acabamento após sinterização; é extensivamente empregada na usinagem de cerâmicas avançadas. Durante o processo de usinagem a verde os esforços de corte determinam a introdução de defeitos críticos na superfície e são geralmente estes defeitos que governam as propriedades mecânicas das cerâmicas após a sinterização. O trabalho objetiva a elaboração e montagem de um sistema de aquisição de dados das forças de usinagem, e procura identificar o limite de agressividade de corte na manutenção da integridade do corpo de prova com produção econômica. As medidas de torque de usinagem e velocidade periférica do rebolo podem representar um modelo para predizer a associação das forças de usinagem. Corpos de prova cilíndricos foram conformados a 100 e 200MPa, tratados termicamente após a prensagem e usinados com diferentes parâmetros de corte, sinterizados e ensaiados quanto à resistência mecânica através de compressão e flexão a quatro pontos. Os resultados mostraram a importância do tratamento térmico antes da usinagem acima da temperatura de transição vítrea do ligante para peças prensadas a 100 e 200MPa. Peças prensadas a 200MPa e tratadas termicamente foram usinadas sem danos a taxas de remoção de $10.000 \mathrm{~mm}^{3} / \mathrm{min}$ com potencia consumida de $1700 \mathrm{~W}$. Com o emprego de um cabeçote com mancais aerostáticos de alta potência e baixo ruído não se detectou a introdução progressiva de defeitos críticos na superfície devido à ação do rebolo, porém se identificou um limite de velocidade de $400 \mathrm{~mm} / \mathrm{min}$ em função da profundidade de corte que excedeu a resistência mecânica dos corpos de prova comprimidos a 100MPa, levando a ruptura. A correlação entre potência consumida e taxa de remoção, forneceu informações muito importantes para o projeto de uma máquina de usinagem á verde de produtos cerâmicos em alumina.

Palavras Chaves: Usinagem a verde, propriedades mecânicas, cerâmicas avançadas, forças de corte. 



\begin{abstract}
Margarido, A. (2011). Influence of the cutting force of green machining on the mechanical properties of sintered ceramics. São Carlos, 2011. 115p. Dissertação (Mestrado) - Escola de Engenharia de São Carlos, Universidade de São Paulo.
\end{abstract}

The present study deals with the measurement forces of green machining ceramics and their correlation with the mechanical properties after sintering. The green machining is employed in crude compacts either to check raw formats without compromising the extreme dimensional accuracy or to obtain a preform prior to finish machining after sintering, extensively used in the machining of advanced ceramics. During the process of the green machining, cutting forces determine the introduction of the critical defects in the surface, which generally govern the mechanical properties after the sintering of ceramics. The study aims at the development and installation of a system of machining forces data acquisition and also the identification of the limit of cutting aggression to maintain the integrity of the ceramics with economic production. The torque measurements of machining and grinding wheel peripheral speed can represent a model to predict the association of the machining forces. Cylindrical bodies were conformed at 100 and $200 \mathrm{MPa}$, heat-treated after pressing and machined with different cutting parameters, sintered and tested concerning strength by compression and bending at four points. The results showed the importance of the heat treatment before machining above the glass transition temperature of the binder for the parts pressed at 100 and $200 \mathrm{MPa}$. Parts pressed at 200MPa and heat-treated were machined without damage at $10.000 \mathrm{~mm}^{3} / \mathrm{min}$ removal rates with power consumption of $1700 \mathrm{~W}$. With the use of a spindle with aerostatic bearings for high power and low noise the gradual introduction of critical defects into the surface was not detected due to the action of the wheel. However a speed limit was identified in function of the depth of the cut, which exceeded the strength of the ceramics compressed at $100 \mathrm{MPa}$, leading to rupture. The correlation between power consumption and rate of removal provided very important information for the design of a green machining of ceramic products in alumina.

Keywords: green machining, mechanical properties, advanced ceramics, cutting forces. 



\section{LISTA DE FIGURAS}

Figura 1 - Linha do tempo dos materiais. (adaptado de UNIVERSIDADE DE SÃO PAULO, 2011)

Figura 2 - Técnicas usuais de obtenção de uma peça de cerâmica avançada, adaptação de REGIANE (1997)........................................................................... 27

Figura 3 - Variação da densidade em peças em função da conformação, em (a) prensagem isostática e em (b) prensagem uniaxial (RICHERSON, 1992).......................... 28

Figura 4 - Desenho esquemático do processo de prensagem isostática Wet Bag, fases de operação em (a) e (b) preenchimento do molde, em (c) pressurização e em (d) massa compactada (REED, 1995).

Figura 5 - Prensagem isostatica Dry Bag. Técnica de molde seco. Fases de operação em (a) pó fluido em (b) preenchimento do molde, em (c) prensagem e em (d) extração da massa compactada (REED, 1995)........................................................... 30

Figura 6 - Mecanismos de compactação (ALBARO, 2000) .............................................. 31

Figura 7 - Variação do grau de compactação do corpo com a pressão de prensagem. Estados de compactação, onde, $\rho \mathrm{D}$ densidade de preenchimento do material, $\mathrm{Pf}$ pressão aparente de fluência do grânulo, pt densidade de compactação, po até pt estágio de máxima compactação, $\rho G$ valor de pressão na qual a compactação do corpo coincide com a do grânulo (ALBARO, 2000).................................... 32

Figura 8 - Variação do volume de poros intragranular $\left(V_{p p}\right)$, intergranular $\left(V_{p g}\right)$ e total $\left(V_{p}\right)$ do corpo em função da pressão de prensagem (ALBARO, 2000)........................... 34

Figura 9 - Variação da distribuição de tamanho de poros do corpo com a pressão de prensagem (P) (ALBARO, 2000). .......................................................... 34

Figura 10 - Variação da compactação do corpo em função da pressão de prensagem (ALBARO, 2000).

Figura 11 - Esquema do processo de spray-drying rotativo e de bico para a realização de fluxo livre de aglomerados de pó esférico contendo um nível uniforme de aditivos em (a) rotativo e em (b) bico, adaptado (RICHERSON, 1992)........................ 37

Figura 12 - Resistência à flexão X Parâmetros de corte (FORTULAN, 2011) ..................... 39

Figura 13 - (A) Redução das interações polímero-polímero e polímero cerâmico com a adição de água. (B) Redução da interação polímero-cerâmica com a adição de água (WU \& McANANY, 1995) apud (REGIANE, 2000)................................. 40

Figura 14 - Influência do avanço (f) em operação de torneamento em oxido de cerâmica a verde (JAHANMIR, 1996).

Figura 15 - Influência da velocidade de corte $\left(v_{c}\right)$ em operação de torneamento em cerâmica a verde (JAHANMIR, 1996)................................................................. 41

Figura 16 - Retificação de uma cerâmica verde em uma retífica vertical (REED,1995)...... 42

Figura 17 - Forças de corte envolvidas na usinagem com rebolo abrasivo (GAMBALE et. al, 2008).

Figura 18 - Esquema representativo de um possível mecanismo de danos ao material. RUFF

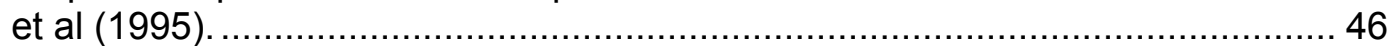

Figura 19 - Modelo de formação teórica do cavaco. (MALKIN \& RITTER, 1989)................. 47

Figura 20 - Efeito da velocidade do rebolo sobre a degradação da resistência mecânica do componente usinado e sobre a força normal aplicada por grão. (MALKIN \& HWANG, 1996)................................................................................... 47

Figura 21 - Comparação do desgaste de ferramenta associado a vários materiais de ferramentas de corte da usinagem a verde de alumina (KLOCKE; GERENT; SCHIPPERS, 1999).

Figura 22 - Desenho esquematico de um grão abrasivo em um filme flexivel. A-grão, bResina deformada, C-vazio devido aos deslocamentos do grão (HIGUCHI et al, 1994) apud (REGIANE, 2000).

Figura 23 - Rz e força de corte resultante $F$ em relação a: (a) Velocidade de corte, (b) Avanço e (c) Profundidade de corte (MAIER; MICHAELI, 1997) ....................... 55

Figura 24 - Controle da Usinagem (MARGARIDO, 2011) ............................................... 57 
Figura 25 - Procedimento de tomada de decisão resumido.

Figura 26 - Desenho esquemático do molde para prensagem isostática (dimensões em mm) (FORTULAN, 2007).

Figura 27 - (A) vista do molde, $(B)$ vista superior do molde para prensagem isostática e (C) tarugo resultante do molde (FORTULAN, 2007).

Figura 28 - Tarugos prensados para obtenção dos corpos de prova a verde (à esquerda) e sinterizado (à direita).

Figura 29 - Tarugo usinado com dimensões 07 X 50mm (MARGARIDO, 2011). ..................62

Figura 30 - Esquema do teste de flexão a 4 pontos (ASTM C-1684-08) ..............................63

Figura 31 - Em (A) Máquina Universal de Ensaios da EMIC e (B) Célula de carga de 20kN

Figura 32 - Imagem da operação de usinagem, em (A) vista lateral e em (B) vista superior.65

Figura 33 - Molde para prensagem isostática do corpo-de-prova. (A) llustração do molde; (B) Blank, resultado da co-prensagem (CAMILO 2010).

Figura 34 - Projeto da manufatura do Implante dentário. (A) conceito em gradiente funcional e em corte (virtual) da camada porosa, (B) Blank pós prensagem, (C) usinagem a verde do Blank, (D) pino sinterizado (CAMILO, 2010).

Figura 35 - Dimensões do pino dental, elaboradas em CAD (A), em (B) ensaios feitos em giz de lousa para conferir as dimensões.....

Figura 36 - Imagem em MEV realizada no pó de alumina e ligantes granulados em spraydrier em (A), (B) e (C) aglomerados esfericos e em (D) vista da superficie de um grânulo.

Figura 37 - Ampliação do tarugo de alumina verde em $100 \mathrm{MPa}$ de compressão, em (A) imagem da massa cerâmica; em (B) a (D) imagens da massa cerâmica com maior magnificação.

Figura 38 - Ampliação do tarugo de alumina verde em 200MPa de compressão, em (A) imagem da massa cerâmica; em (B) a (D) imagens da massa cerâmica com maior magnificação.

Figura 39 - Comparativo de resistência mecânica obtido por flexão a 4 pontos, para corpos de prova sinterizados tratados de maneiras diferentes.

Figura 40 - Pinos usinados a verde e sinterizados em cadinhos de alumina, identificados em sua parte inferior. Em (A) vista de um cadinho no forno, em (B) vista com 9 cadinhos carregados com 5 amostras cada, em (C) vista das peças e em (D) um grupo de peças com identificação em sua base .

Figura 41 - Resistencia mecânica $X$ profundidade de corte para corpos de prova prensados a $100 \mathrm{MPa}$ e sinterizados............................................................................. 76

Figura 42- Em (A) o primeiro projeto de maquina para usinagem a verde e $(B)$ o banco de ensaios inicial criado por Gambale 2008;

Figura 43 - Em (A) o projeto adaptativo da maquina de usinagem a verde sendo (A) (1) Spindle, (2) Sensor de torque, (3) Blank e (4) Servo motor, em B) o protótipo funcional, em (C) o suporte do Spindle e em (D) uma vista em detalhe do conjunto............................................................................................ 77

Figura 44 - Porta ferramentas e suporte para fixação do Spindle, em (A) o projeto feito em $C A D$, em (B) o suporte do porta ferramenta usinado, em (C) e (D) a instalação dos componentes do porta ferramentas. ...................................................... 78

Figura 45 -Circuito de Ar para alimentação do Spindle aerostático - em (A) circuito de filtragem do ar para o Spindle em (B) acumulador, e em (C) Diagrama para pressurização do Spindle - (1) entrada de ar, (2) válvula direcional, (3) válvula, (4) silenciadores, (5) regulador de pressão, (6) manômetro, (7) acumulador, (8) a (10) filtros de ar e em (11) Spindle aerostático............................................. 79

Figura 46 - Interface de controle de maquina CNC, em (A) o kit comercial, em (B) e o kit montado e em (D) e (D) o driver completo pronto para controlar os motores de passo....... 
Figura 47 - Em (A) e (B) Projeto virtual do banco conceitual feito em estrutura de granito sintético, com acionamento dos eixos $X Y$ através de servo-motores e equipado com Spindle aerostático......

Figura 48 - Gráfico de Torque X Tempo, a media dos pontos mais baixos representa o repouso e a media dos 5 maiores pontos, o torque máximo.

Figura 49 - Usinagem á verde $F=100 \mathrm{~mm} / \mathrm{min}$ e $A=0,5 \mathrm{~mm} 100 \mathrm{MPa}$, em (A) superfície da amostra após usinagem, em (B) imagem da superfície por MEV, em (C) maior magnificação e em (D) gráfico do ensaio de flexão a quatro pontos após sinterização.

Figura 50 - Usinagem á verde $F=200 \mathrm{~mm} / \mathrm{min}$ e $A=0,5 \mathrm{~mm} 100 \mathrm{MPa}$, em $(A)$ superfície da amostra após usinagem, em (B) imagem da superfície por MEV, em (C) maior magnificação e em (D) gráfico do ensaio de flexão a quatro pontos após sinterização.

Figura 51 - Usinagem á verde $F=300 \mathrm{~mm} / \mathrm{min}$ e $A=0,5 \mathrm{~mm} 100 \mathrm{MPa}$, em (A) superfície da amostra após usinagem, em (B) imagem da superfície por MEV, em (C) maior magnificação e em (D) gráfico do ensaio de flexão após sinterização. ............... 85

Figura 52 - Usinagem á verde $F=400 \mathrm{~mm} / \mathrm{min}$ e $A=0,5 \mathrm{~mm} 100 \mathrm{MPa}$, em (A) superfície da amostra após usinagem, em (B) imagem da superfície por MEV, em (C) maior magnificação e em (D) gráfico do ensaio de flexão após sinterização.

Figura 53 - Usinagem á verde $F=100 \mathrm{~mm} / \mathrm{min}$ e $A=1 \mathrm{~mm} 100 \mathrm{MPa}$, em $(A)$ superfície da amostra após usinagem, em (B) imagem da superfície por MEV, em (C) maior magnificação e em (D) gráfico do ensaio de flexão após sinterização................ 86

Figura 54 - Usinagem á verde $F=200 \mathrm{~mm} / \mathrm{min}$ e $A=1 \mathrm{~mm} 100 \mathrm{MPa}$, em (A) superfície da amostra após usinagem, em (B) imagem da superfície por MEV, em (Cc) maior magnificação e em (D) gráfico do ensaio de flexão após sinterização. ................ 86

Figura 55 - Usinagem á verde $F=300 \mathrm{~mm} / \mathrm{min}$ e $A=1 \mathrm{~mm} \quad 100 \mathrm{MPa}$, em (A) superfície da amostra após usinagem, em (B) imagem da superfície por MEV, em (C) maior magnificação e em (D) gráfico do ensaio de flexão após sinterização. ............... 87

Figura 56 - Usinagem á verde $F=400 \mathrm{~mm} / \mathrm{min}$ e $A=1 \mathrm{~mm} 100 \mathrm{MPa}$, em (A) superfície da amostra após usinagem, em (B) imagem da superfície por MEV, em (C) maior magnificação e em (D) gráfico do ensaio de flexão após sinterização. ...............87 87

Figura 57 - Usinagem á verde $F=100 \mathrm{~mm} / \mathrm{min}$ e $A=1 \mathrm{~mm} 200 \mathrm{MPa}$, em (A) imagem da superfície por MEV, em (B) maior magnificação e em (C) gráfico do ensaio de flexão a 4 pontos após sinterização............................................................. 88

Figura 58- Usinagem á verde $F=200 \mathrm{~mm} / \mathrm{min}$ e $A=1 \mathrm{~mm} 200 \mathrm{MPa}$ em (A) imagem da superfície por MEV, em (B) maior magnificação e em (C) gráfico do ensaio de flexão a quatro pontos após sinterização........................................................ 88

Figura 59 - Usinagem á verde $F=300 \mathrm{~mm} / \mathrm{min}$ e $A=1 \mathrm{~mm} 200 \mathrm{MPa}$, em $(A)$ imagem da superfície por MEV, em (B) maior magnificação e em (C) gráfico do ensaio de flexão a quatro pontos após sinterização.

Figura 60 - Usinagem á verde $F=400 \mathrm{~mm} / \mathrm{min}$ e $A=1 \mathrm{~mm} 200 \mathrm{MPa}$, em $(A)$ imagem da superfície por MEV, em (B) maior magnificação e em (C) gráfico do ensaio de flexão a quatro pontos após sinterização.

Figura 61 - Cavaco tarugo 100MPa Não Tratado, $F=100 \mathrm{~mm} / \mathrm{min}$ e $A=0,5 \mathrm{~mm}$, em (A) imagem do cavaco por MEV, em (B) e (C) maior magnificação e em (D) gráfico do ensaio de flexão a quatro pontos com a amostra a verde.

Figura 62 - Cavaco tarugo $100 \mathrm{MPa}$ Tratado, $F=100 \mathrm{~mm} / \mathrm{min}$ e $A=0,5 \mathrm{~mm}$, em $(A)$ imagem do cavaco por MEV, em (B) e (C) maior magnificação em (D) gráfico do ensaio de flexão a quatro pontos com a amostra a verde e em (E) ensaio de compressão com a amostra a verde.

Figura 63 - Cavaco tarugo 200MPa Não Tratado, $F=100 \mathrm{~mm} / \mathrm{min}$ e $A=0,5 \mathrm{~mm}$, em (A) imagem do cavaco por MEV, em (B) e (C) maior magnificação e em (D) gráfico do ensaio de flexão a quatro pontos com a amostra a verde.

Figura 64 - Cavaco tarugo 200MPa Tratado, F=100mm/min e A-0,5mm, , em (A) imagem do cavaco por MEV, em (B) e (C) maior magnificação em (D) gráfico do ensaio de 
flexão a quatro pontos com a amostra a verde e em e) ensaio de compressão com a amostra a verde.

Figura 65 - Tarugo Sinterizado 100MPA - 183kg ruptura, em (A) até (D) maior magnificação.

Figura 66 - Tarugo Sinterizado 100MPA - 255kg ruptura, em (A) até (D) maior magnificação.

Figura 67 - Resistência mecânica das amostras sinterizadas em função da taxa de remoção.

Figura 68 - Resistencia mecânica em função da taxa de remoção, amostras comprimidas a 200MPa com profundidade de corte de $1 \mathrm{~mm}$.

Figura 69 - Potência de corte consumida em função da taxa de remoção $100 \mathrm{MPa}$........... 97

Figura 70 - Potência de corte consumida em função da taxa de remoção $200 \mathrm{MPa}$........... 97

Figura 71 - Gráfico Avanço X Resistencia Mecânica para corpos de prova prensados a 100 $\mathrm{MPa}$.

Figura 72 - Gráfico Avanço X Resistencia Mecânica para corpos de prova prensados a 200 $\mathrm{MPa}$.

Figura 73 - Gráfico Avanço X Torque para corpos de prova prensados a $100 \mathrm{MPa}$.

Figura 74 - Gráfico Avanço X Torque para corpos de prova prensados a $200 \mathrm{MPa}$. 99

Figura 75 - Gráfico Taxa de remoção X Torque para corpos de prova prensados a $100 \mathrm{MPa}$.

Figura 76 - Gráfico Taxa de remoção X Torque para corpos de prova prensados a $200 \mathrm{MPa}$.

Figura 76 - Grafco Taxa de remoçä X Torque para corpos de prova prensados a 200 100

Figura 77 - Em a) condicionador de sinal PCB PIEZOTRONICS, modelo: 482B11 e em b) PCB acelerômetro PIEZOTRONICS, modelo 353B03...

Figura 78 - Sinal base, equipamento ligado sem exercer usinagem............................. 101

Figura 79 - Análise vibratória para usinagem a verde com profundidade de corte fixa em $0.5 \mathrm{~mm}$ e em (A) avanço de $100 \mathrm{~mm} / \mathrm{min}$, em (B) $200 \mathrm{~mm} / \mathrm{min}$, em (C) $300 \mathrm{~mm} / \mathrm{min}$ e em (D) $400 \mathrm{~mm} / \mathrm{min}$.

Figura 80 - Análise vibratória para usinagem a verde com profundidade de corte fixa em $1 \mathrm{~mm}$ e em (A) avanço de $100 \mathrm{~mm} / \mathrm{min}$, em (B) $200 \mathrm{~mm} / \mathrm{min}$, em (C) $300 \mathrm{~mm} / \mathrm{min}$ e em (D) $400 \mathrm{~mm} / \mathrm{min}$.

Figura 81 - Usinagem de Blank no formato de pino de dente. (A) Blank fixado no suporte. (B) Blank durante usinagem. (C) Usinagem em fase final de acabamento. (D) Pino usinado.

Figura 82 - Pino dentário sinterizado em (A) denso, (B) com gradiente funcional de porosidade. 


\section{LISTA DE TABELAS}

Tabela 1 - Funções dos aditivos (PANDOLFELLI et al, 1981). 35

Tabela 2 - Propriedades de alguns materiais para ferramentas (JAHANMIR, 1996) ............... 52

Tabela 3 - concentração de diversos materiais contidos na alumina.................................... 60

Tabela 4 - Condições de usinagem............................................................................. 64

Tabela 5 - Investimento praticado no protótipo do banco de ensaios, excetuado mão de obra

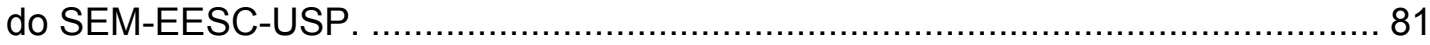

Tabela 6 - Resultados de diferentes parâmetros na usinagem a verde ................................ 95 



\section{LISTA DE ABREVIATURAS E SIGLAS}

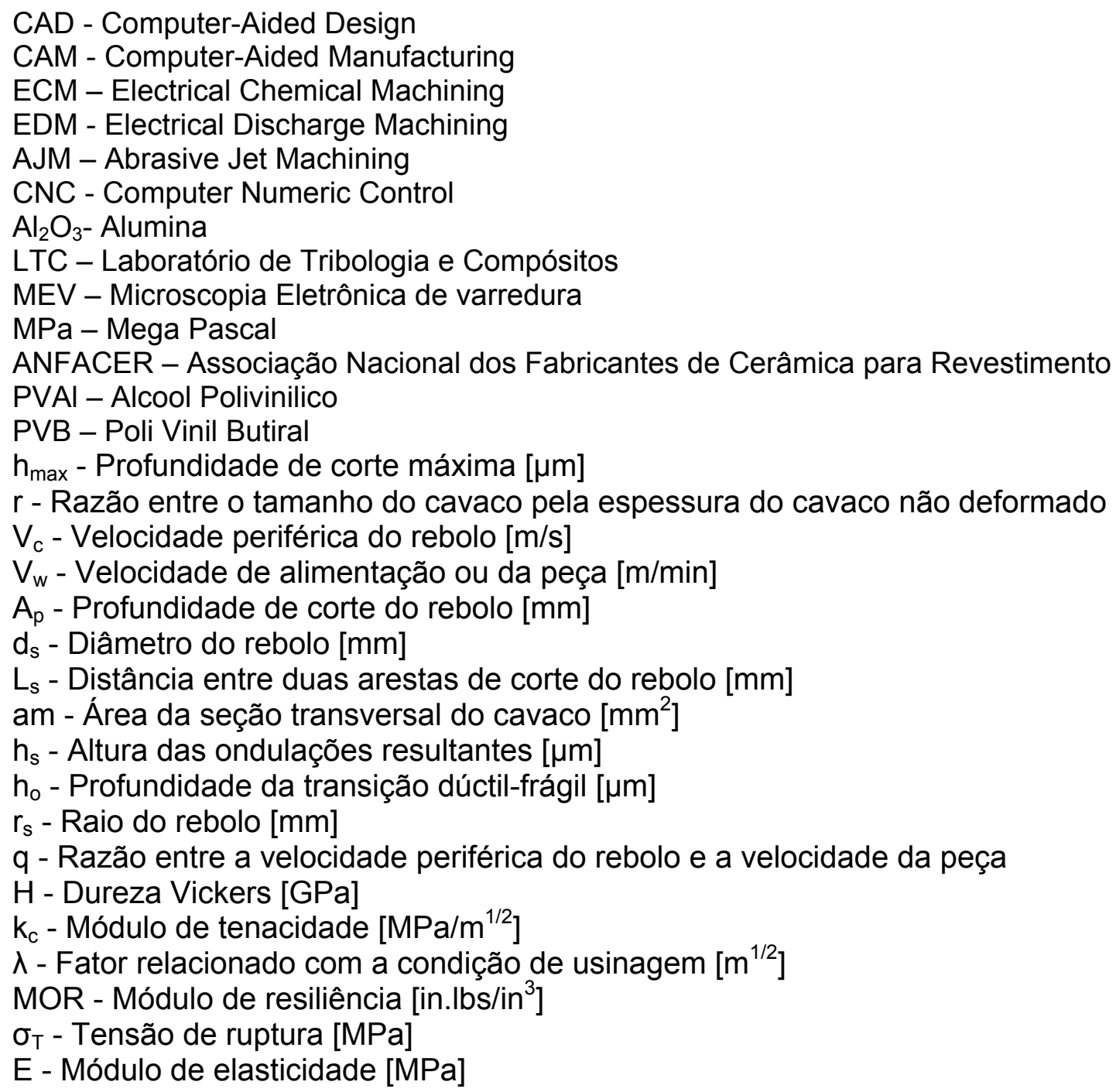





\title{
SUMÁRIO
}

\author{
RESUMO \\ ABSTRACT \\ LISTA DE FIGURAS \\ LISTA DE QUADROS \\ LISTA DE ABREVIATURAS E SIGLAS
}

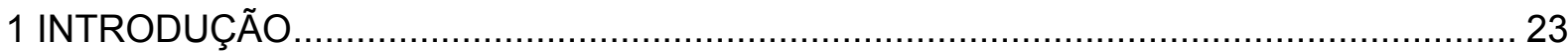

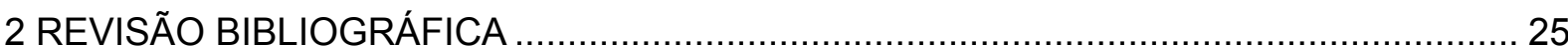

2.1 Processos de Conformação Cerâmica …......................................................... 27

2.1.1 Prensagem isostática a frio........................................................... 28

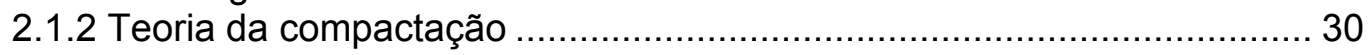

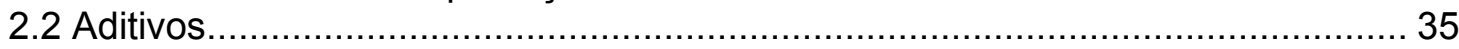

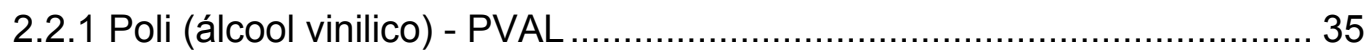

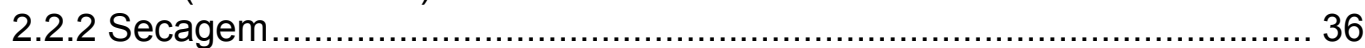

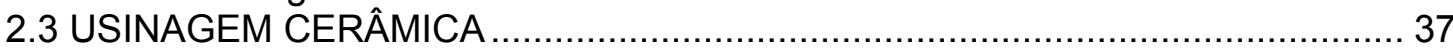

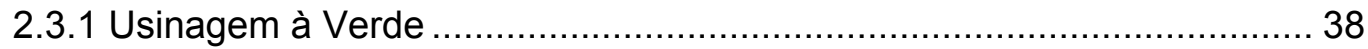

2.3.2 Equipamentos - Usinagem por retificação .......................................... 42

2.3.3 Modelos de remoção de material....................................................... 45

2.3.4 Efeito da profundidade de corte na remoção de material e na geração de

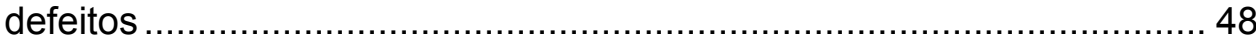

2.3.5 Forças de retificação..................................................................... 48

2.3.6 Efeitos da retificação associados ao Green Machining .......................... 49

2.3.7 Ferramentas de Corte .................................................................... 51

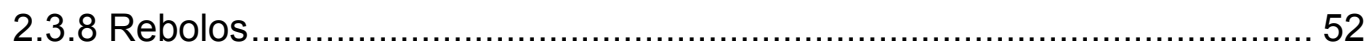

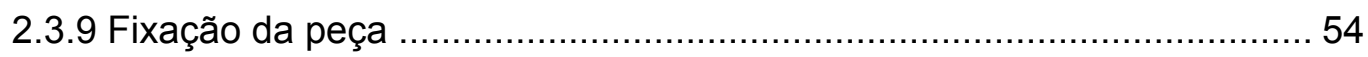

2.3.10 Velocidade de Usinagem ............................................................ 55

2.3.11 Parâmetros de Usinagem .......................................................... 55

2.3.12 Usinagem pós sinterização............................................................. 56

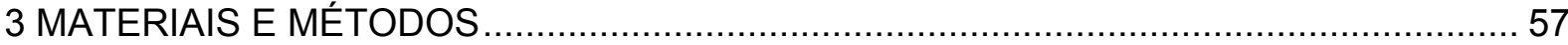

3.1 Projeto do banco de ensaios de usinagem .................................................. 58

3.1.1 Identificação da demanda............................................................... 58

3.1.2 Conclusão da análise de viabilidade............................................... 59

3.1.3 Projeto adaptativo em banco anterior de Gambale (2008) ..................... 59

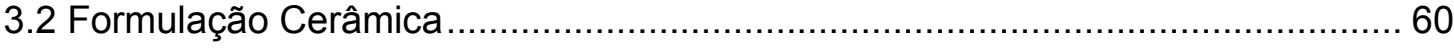

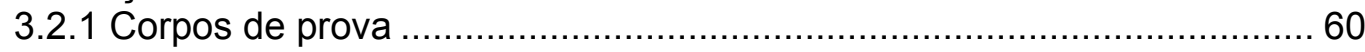

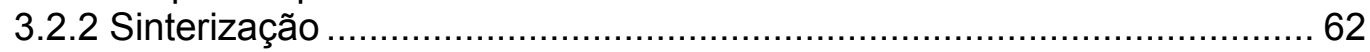

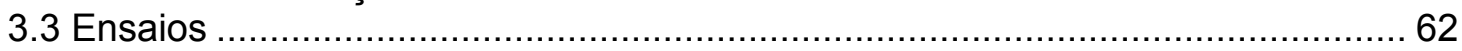

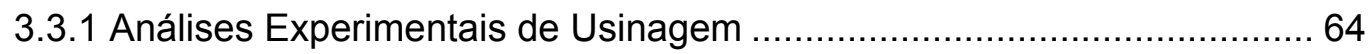

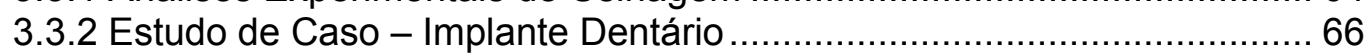

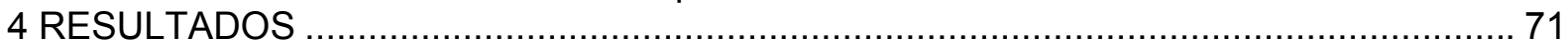

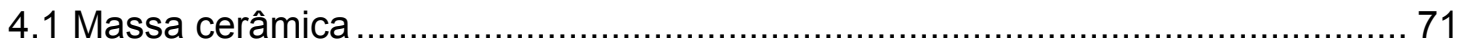

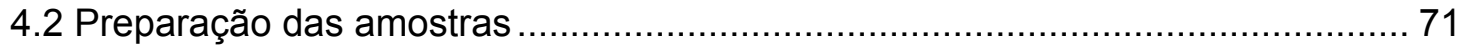

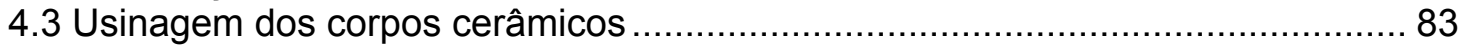

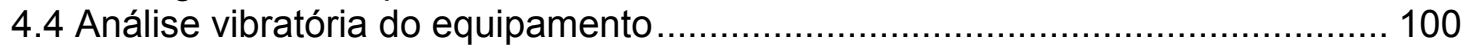

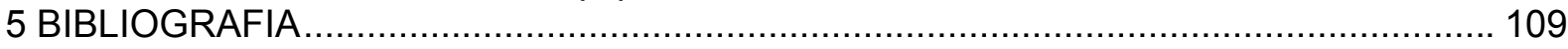





\section{INTRODUÇÃO}

A usinagem a verde é um método alternativo para a fabricação rápida de peças cerâmicas com formatos complexos, onde a cerâmica é usinada no estado verde "não sinterizado" através da tecnologia CAD/CAM. Diferentes técnicas de fabricação por usinagem têm sido investigadas desde o final dos anos 80, incluindo sistemas ultrassônicos, descargas elétricas (EDM), sistemas a laser, usinagem eletroquímica (ECM) e usinagem com jato abrasivo (AJM), todas com alto custo de desenvolvimento inicial e restrições sobre os tipos de materiais que podem ser trabalhados, limitando a utilização destes processos. Processos de usinagem de cerâmica, geralmente são empregados para alta precisão, formatos complexos e são ainda economicamente viáveis. Atualmente a usinagem é controlada através de comando numérico $(\mathrm{CNC})$, pelo qual um modelo CAD 3D é primeiro decomposto ou cortado em representações em finas camadas longitudinais. Em seguida, cada camada é seletivamente removida até se alcançar o formato e as dimensões desejadas. É extremamente útil em algumas aplicações como implantes ortopédicos ou restaurações dentárias, onde a cerâmica ou bio-cerâmica tem sido usada para fabricação de próteses. (SU et al., 2008)

A operação de usinagem a verde é de baixo consumo energético e de grande capacidade de remoção de material, não exigindo ferramentas extremamente duras. Contudo, a velocidade de corte é limitada para a retificação devido a baixa resistência mecânica que estes componentes apresentam neste estado, geralmente inferiores a $8 \mathrm{MPa}$. (KAMBOJ et al, 2003; KEVIN, WU X. L. et al., 1995). O Processo de retificação tem sido utilizado na usinagem a verde há décadas na fabricação de velas de ignição, dedais de sondas lambda, filtros cerâmicos. Scheller (1996) afirmava que pesquisas na área de usinagem a verde de cerâmicas são extremamente limitadas. Embora extensivamente aplicada na indústria, pouco se relata à respeito da otimização do processo, seleção de rebolos abrasivos e defeitos críticos introduzidos durante a usinagem.

Estudos mostram a influência da pressão de compactação na qualidade da usinagem à verde, com o aumento da pressão de compactação o mecanismo de remoção de material atravessa a fase inicial de fratura inter-aglomerado para uma fase mista e subsequente fase intra-aglomerado, onde se verifica maiores danos superficiais (KAMBOJ et al, 2003). Este aspecto demonstra a necessidade de estudar os efeitos das variáveis da conformação (umidade da matéria prima, pressão de compactação, tempo) em função das variáveis de remoção de material durante a usinagem.

Retificação é o processo de usinagem por abrasão que remove material da peça através da ação de grãos abrasivos da superfície do rebolo. 
O controle das forças de usinagem pode ser implementado para otimização do processo. Através de estudos experimentais foi observada a correlação entre a agressividade do corte e a resistência mecânica do corpo de provas (GAMBALE et. al, 2008).

\section{OBJETIVOS}

O objeto de estudo desse trabalho é a determinar a influência dos esforços de corte na integridade do corpo cerâmico a verde de alumina, conformado em diferentes pressões e preparo da matéria prima. Os esforços do corte determinam a introdução de defeitos críticos na superfície e sub-superfície que governam a resistência do produto acabado. Busca-se por uma faixa otimizada de valores de torque para estabelecer os parâmetros de controle da usinagem onde o avanço pode ser controlado de acordo com a agressividade da usinagem dentro de limites estabelecidos, obtendo as propriedades mecânicas desejadas. 


\section{REVISÃO BIBLIOGRÁFICA}

A cerâmica é o material artificial mais antigo produzido pelo homem, existindo a cerca de dez a quinze mil anos. Do grego "kéramos", "terra queimada" ou "argila queimada" é um material de imensa resistência, sendo frequentemente encontrado em escavações arqueológicas. Quando saiu das cavernas e se tornou um agricultor, o homem necessitava não apenas de um abrigo, mas de vasilhas para armazenar a água, os alimentos colhidos e as sementes para a próxima safra. Tais vasilhas tinham que ser resistentes ao uso, impermeáveis a umidade e de fácil fabricação. Essas facilidades foram encontradas na argila, deixando pistas sobre civilizações e culturas que existiram milhares de anos antes da Era Cristã. A cerâmica a partir da argila é uma atividade de produção de artefatos, que se torna muito plástica e fácil de moldar quando umedecida. Depois de submetida a uma secagem para retirar a maior parte da água, a peça moldada é submetida a altas temperaturas ao redor de $1.000^{\circ} \mathrm{C}$, que the atribuem rigidez e resistência mecânica, mediante a fusão de certos componentes da massa, e em alguns casos fixando os esmaltes na superfície. Essas propriedades permitiram que a cerâmica fosse utilizada na construção de casas, vasilhames para uso doméstico e armazenamento de alimentos, vinhos, óleos, perfumes, na construção de urnas funerárias e até como "papel" para escrita. A cerâmica pode ser uma atividade artística, em que são produzidos artefatos com valor estético, ou uma atividade industrial em que são produzidos artefatos para uso na construção civil e engenharia (ANFACER, 2011).

Hoje em dia, além de sua utilização como matéria-prima constituinte de diversos instrumentos domésticos, da construção civil e como material plástico nas mãos dos artistas, a cerâmica é também utilizada na tecnologia de ponta, aplicações na engenharia que incluem componentes de motores, sistemas de defesa, próteses e isoladores elétricos. $\mathrm{Na}$ área médica são encontradas aplicações nobres para esse material. A aplicação de diferentes tipos de materiais varia de acordo com o domínio das técnicas de produção empregadas. Ao se aprimorar as técnicas, reduzindo-se tempo, custos e aumentando a qualidade, maior será sua aceitação na indústria e em outros setores econômicos. A Figura 1 exibe o auge de utilização dos diferentes tipos de materiais durante a história. A tendencia é um aumento na demanda por materiais cerâmicos devido a suas propriedades físicas, inércia química, dureza, resistência mecânica, resistência ao desgaste, baixo peso específico, resistência ao calor entre outros (FORTULAN, 1997). 


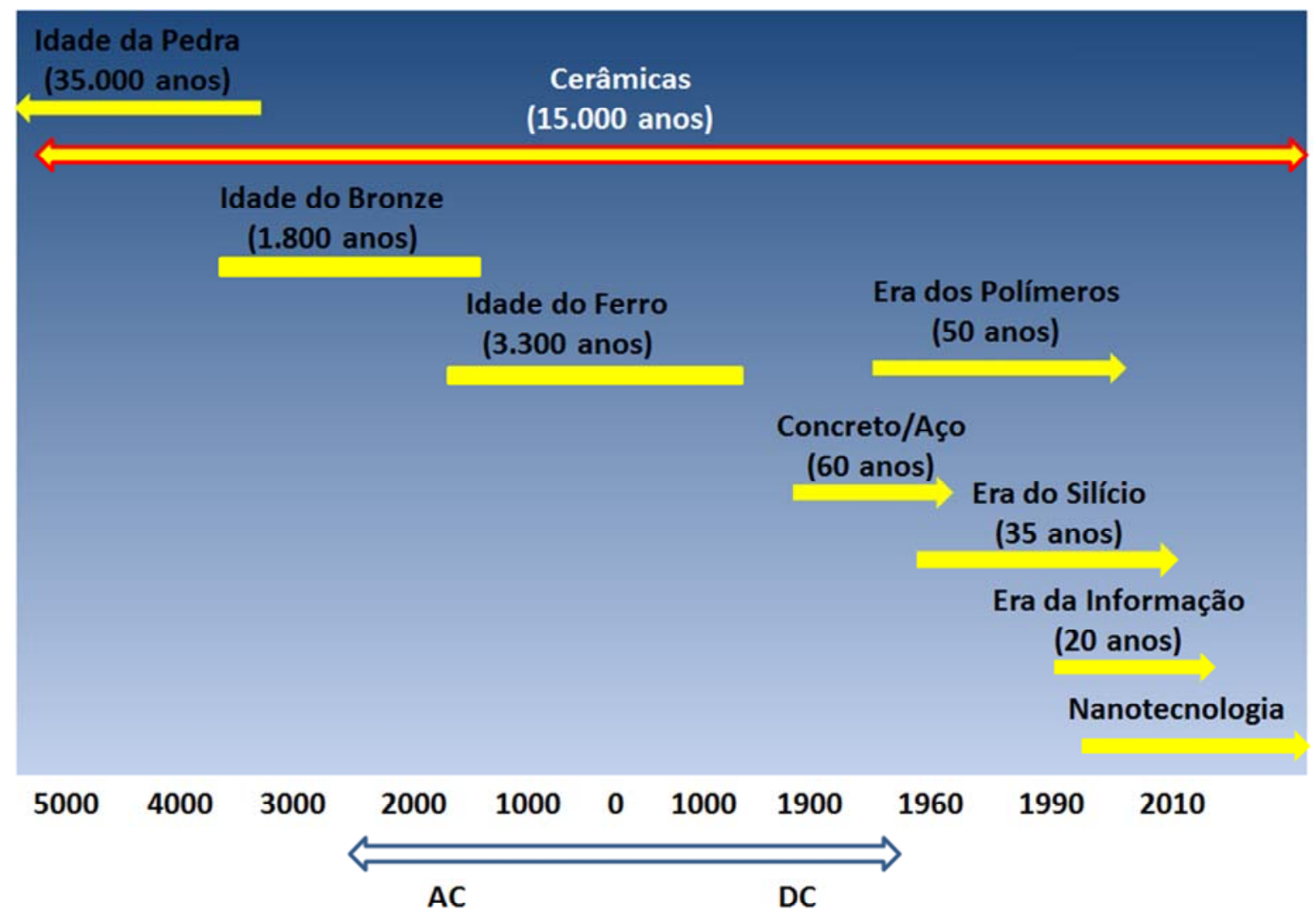

Figura 1 - Linha do tempo dos materiais. (adaptado de UNIVERSIDADE DE SÃO PAULO, 2011)

O aumento da demanda por cerâmicas estruturais avançadas tem um grande obstáculo que é o problema da produção em massa das formas desejadas, dentro de certas tolerâncias e rugosidades, com aceitável confiabilidade. Atualmente, uma das principais dificuldades da indústria de cerâmica avançada é produzir produtos rapidamente, com valores competitivos. Praticamente toda produção de componentes cerâmicos, provem de pós ou misturas de pós, conformados através de prensagem, extrusão, colagem ou injeção em moldes, e depois submetidos a calor para a sinterização. A fabricação de formatos complexos de cerâmica avançada com boa precisão dimensional e uniformidade nas propriedades mecânicas só podem ser consequidas por algumas poucas técnicas de conformação (HEIMKE, 1987; NOGUEIRA, 1992).

As técnicas tradicionais de processamento de peças cerâmicas estão dispostas na Figura 2. 


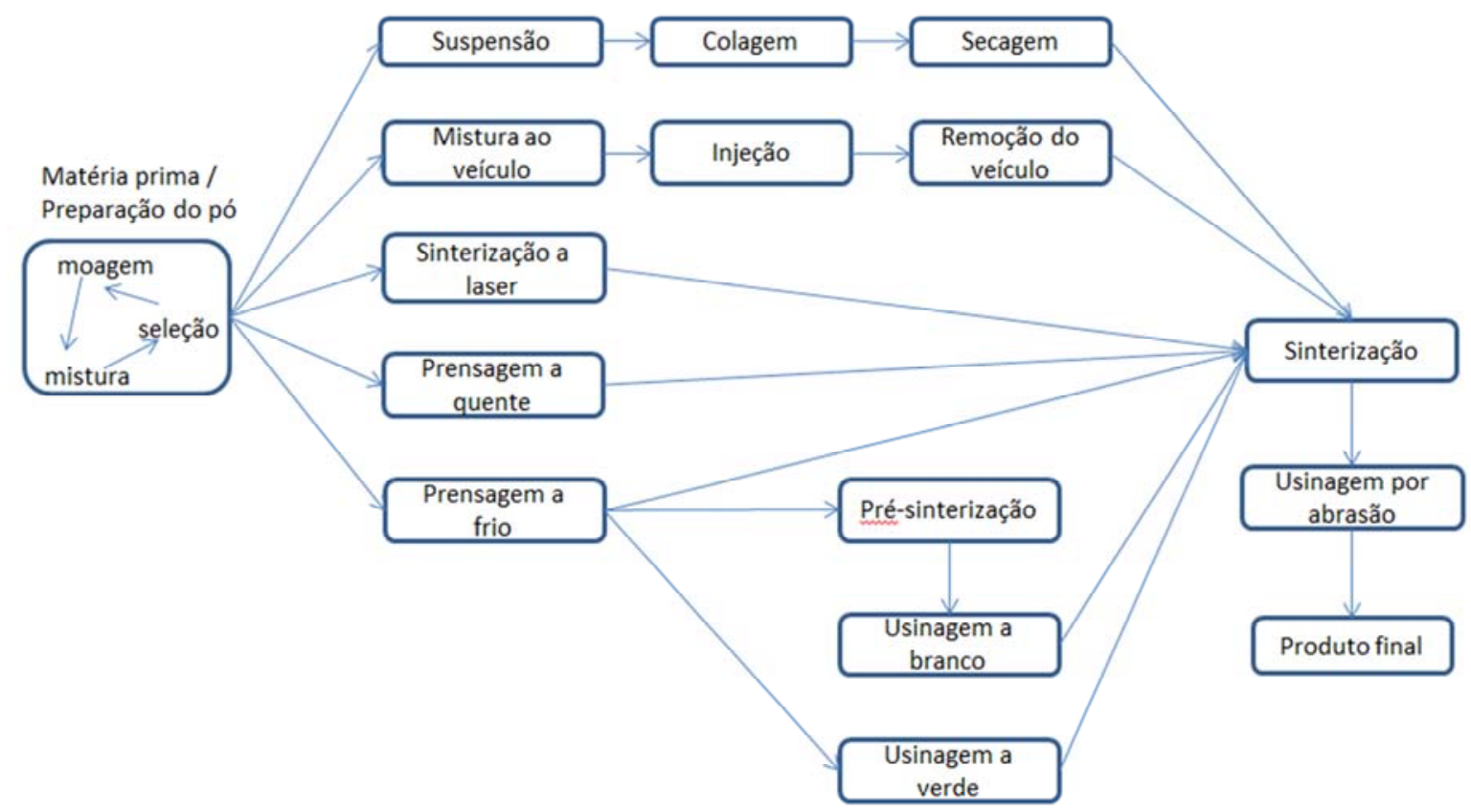

Figura 2 - Técnicas usuais de obtenção de uma peça de cerâmica avançada, adaptação de REGIANE (1997).

Os processos de conformação mais utilizados industrialmente são a colagem, injeção em moldes ou a prensagem, seguidos de usinagem ou não da peça cerâmica. Novos métodos de conformação e sinterização vêm sendo estudados para o aumento da produção em larga escala e a redução de custos de planejamento e desenvolvimento de produtos em cerâmica avançada. Atualmente há também a preocupação sobre a toxidade e a destruição do meio ambiente pelos processos de produção de cerâmica e sua utilização. Estes aspectos da cerâmica vêm sendo hoje normatizados (RAE, 1994).

\subsection{Processos de Conformação Cerâmica}

Para se reduzir o tempo de produção, conforma-se o pó ceramico em formatos e dimensões próximos ao produto final e por meio de usinagem, geralmente abrasiva, corrigem-se as imperfeições no atendimento das dimensões desejadas.

Os processos de conformação também visam a maior produtividade a um menor custo e constituem, muitas vezes, a única forma viável para obtenção de uma peça de formato complexo como é o caso de rotores de turbinas. Cada processo de conformação, influencia de forma diferente a camada superficial da peça a ser usinada, principalmente através da ocorrência de uma compactação dos pós maior na parte externa que na interna, gerando uma diferença na dinâmica de formação de grãos cristalinos da microestrutura no processo de densificação (TING \& LIN, 1994 - 1995, RICHERSON, 1992, BANDYOPADHYAY \& FRENCH, 1994). 


\subsubsection{Prensagem isostática a frio}

Com a aplicação da pressão em todas as direções ocorre uma grande uniformidade na compactação das peças, independente de sua forma, mostrado na Figura 3 onde foram comparadas (a) prensagem isostática e (b) prensagem uniaxial. Na prensagem isostática, geralmente são empregados dois tipos: a de via úmido (Wet Bag) e via a seco (Dry Bag) (RICHERSON, 1992).

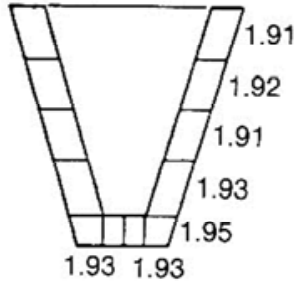

(a)

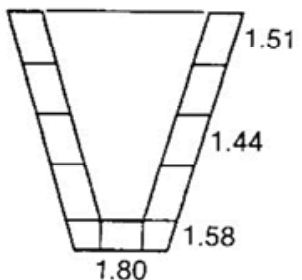

(b)

Figura 3 - Variação da densidade em peças em função da conformação, em (a) prensagem isostática e em (b) prensagem uniaxial (RICHERSON, 1992).

Na prensagem isostática Wet Bag, o pó cerâmico é introduzido no interior de um molde flexível e impermeável ao fluído pressurizado. Uma vez fechado, o molde é submerso no líquido (geralmente água com adição de óleo solúvel) contido na câmara de pressão, a Figura 4 ilustra esquematicamente este processo. Na fase de compactação, o líquido é pressurizado por uma bomba hidráulica, e deforma o molde flexível que transmite uniformemente a pressão à massa. Uma vez completo o ciclo de compactação, à medida que é reduzida a pressão do líquido ocorre uma expansão tanto do molde como da peça, o que facilita sua extração.

Ainda que qualquer fluido incompressível possa ser utilizado, o mais empregado é a água com adição de um óleo solúvel para lubrificar e proteger as partes metálicas contra a corrosão. O molde flexível é um elastômero, como o poliuretano. Sua flexibilidade e a espessura da parede devem ser cuidadosamente selecionadas. 


\section{Wet Bag}
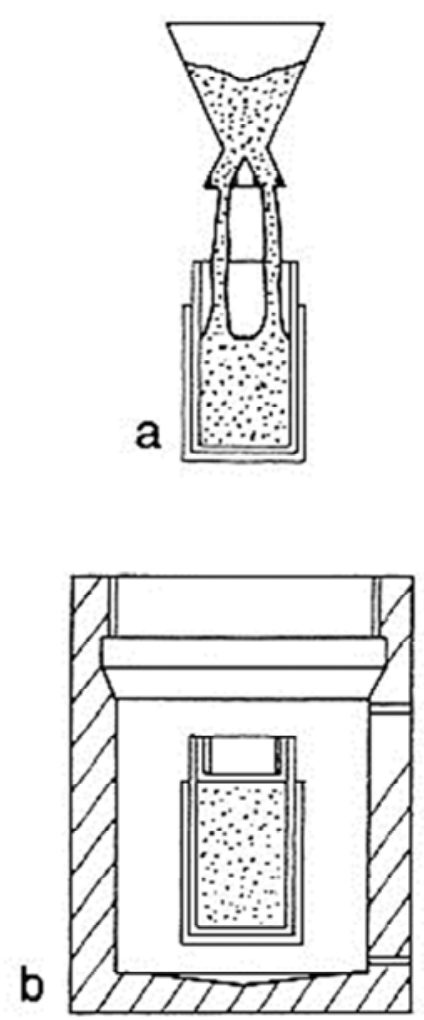

C

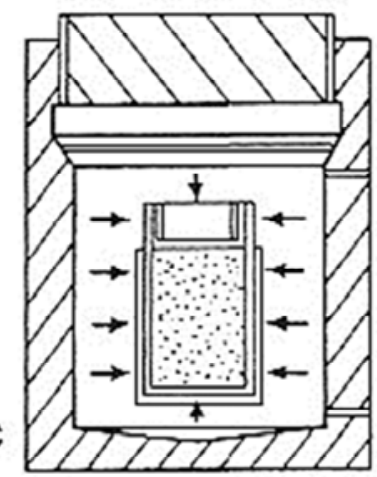

Figura 4 - Desenho esquemático do processo de prensagem isostática Wet Bag, fases de operação em (a) e (b) preenchimento do molde, em (c) pressurização e em (d) massa compactada (REED, 1995).

Em escala de laboratório existem no mercado prensas capazes de alcançar pressões da ordem de $1400 \mathrm{MPa}$. As prensas industriais, entretanto, não superam os 400 $\mathrm{MPa}$. As principais vantagens desta técnica são a obtenção de peças com uma distribuição de compacidade praticamente homogênea, grande versatilidade de formas e baixo custo do molde.

As principais desvantagens são a excessiva duração do ciclo de prensagem, da ordem de minutos, a dificuldade de se automatizar a operação e o elevado custo de mão-deobra. A etapa mais demorada da operação é o preenchimento do molde (ALBARO, 2001).

A prensagem isostática a seco Dry Bag, foi desenvolvida para aumentar a velocidade de produção da técnica via úmido. Basicamente, nesta técnica, em vez de submergir o molde em um fluido, ele é feito com canais internos por onde se faz circular o fluido pressurizado (Figura 5). Isto minimiza a quantidade de fluido a ser pressurizado e permite o uso de uma ferramenta estacionária. O maior desafio do processo é a construção adequada do molde para a transmissão uniforme de pressão para o pó cerâmico atingir o formato desejado, que além de ser mecanicamente resistente deve ser capaz de transmitir 
de maneira uniforme a pressão à massa. Uma vez obtido um desenho e construção de moldes adequados, a operação pode ser automatizada e velocidades de até 1500 ciclos por hora podem ser atingidas (ALBARO, 2001).

\section{Dry Bag}
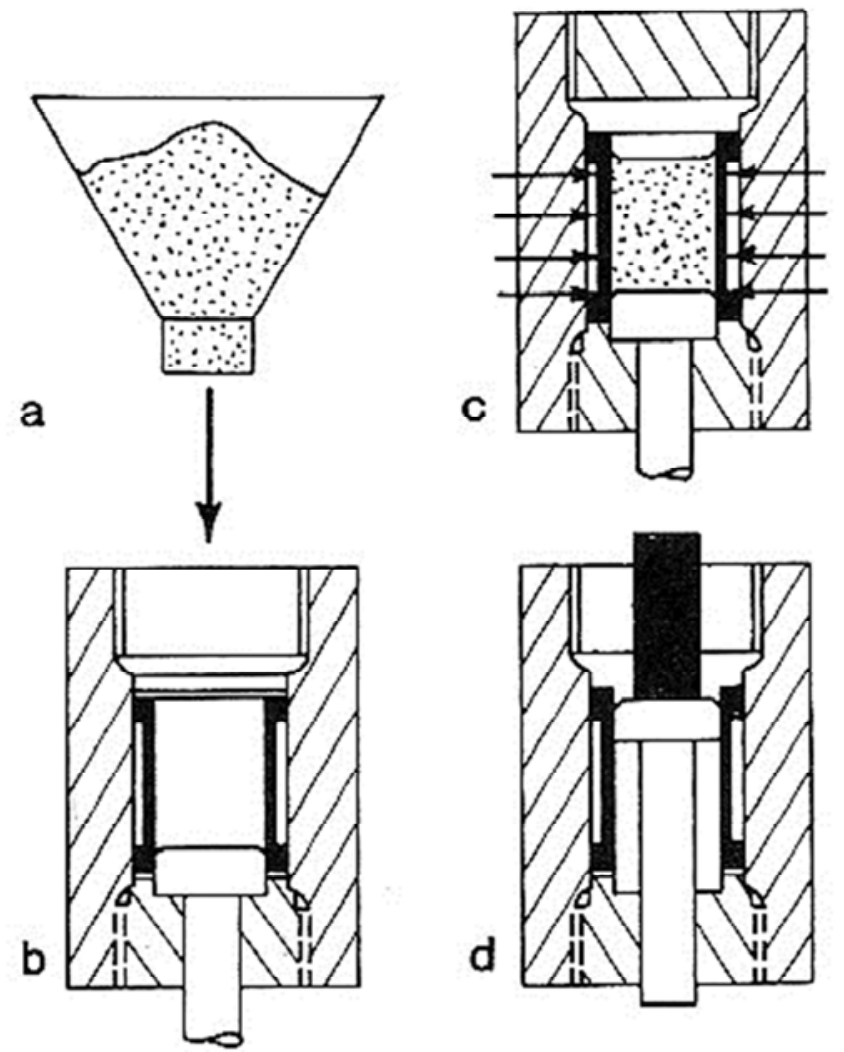

Figura 5 - Prensagem isostatica Dry Bag. Técnica de molde seco. Fases de operação em (a) pó fluido em (b) preenchimento do molde, em (c) prensagem e em (d) extração da massa compactada (REED, 1995).

\subsubsection{Teoria da compactação}

Quando o pó cerâmico é submetido a uma tensão de compressão suficientemente elevada (unidirecional ou isostática) podem ocorrer os seguintes processos, fenômenos ou trocas, como se segue.

- Compressão permanente do material, a compactação do corpo se mantem depois de retirada a carga. Este processo implica basicamente no fluxo, na reordenação, na deformação plástica e na destruição dos grânulos, no intervalo de baixas pressões de prensagem, e no deslizamento e reordenação das partículas que constituem os grânulos em pressões habituais de prensagem. 
- Compressão elástica das partículas, ligantes e lubrificantes líquidos, bem como do gás presente no corpo. Quando a carga é eliminada, ocorre uma ligeira expansão do material.

- Um fluxo de líquidos e gases através dos poros do corpo por fluxo viscoso, devido aos gradientes de pressão estabelecidos ao longo dos distintos pontos da peça.

- Se a prensagem é uniaxial, o atrito entre as partículas e estas com as paredes do molde provoca uma distribuição heterogênea da pressão de compactação no volume do material.

\subsubsection{Estados e mecanismos da compactação}

$\mathrm{Na}$ compactação de um material granular (massa) a diminuição do volume dos poros e de seus tamanhos ocorre através de três mecanismos (Figura 6).

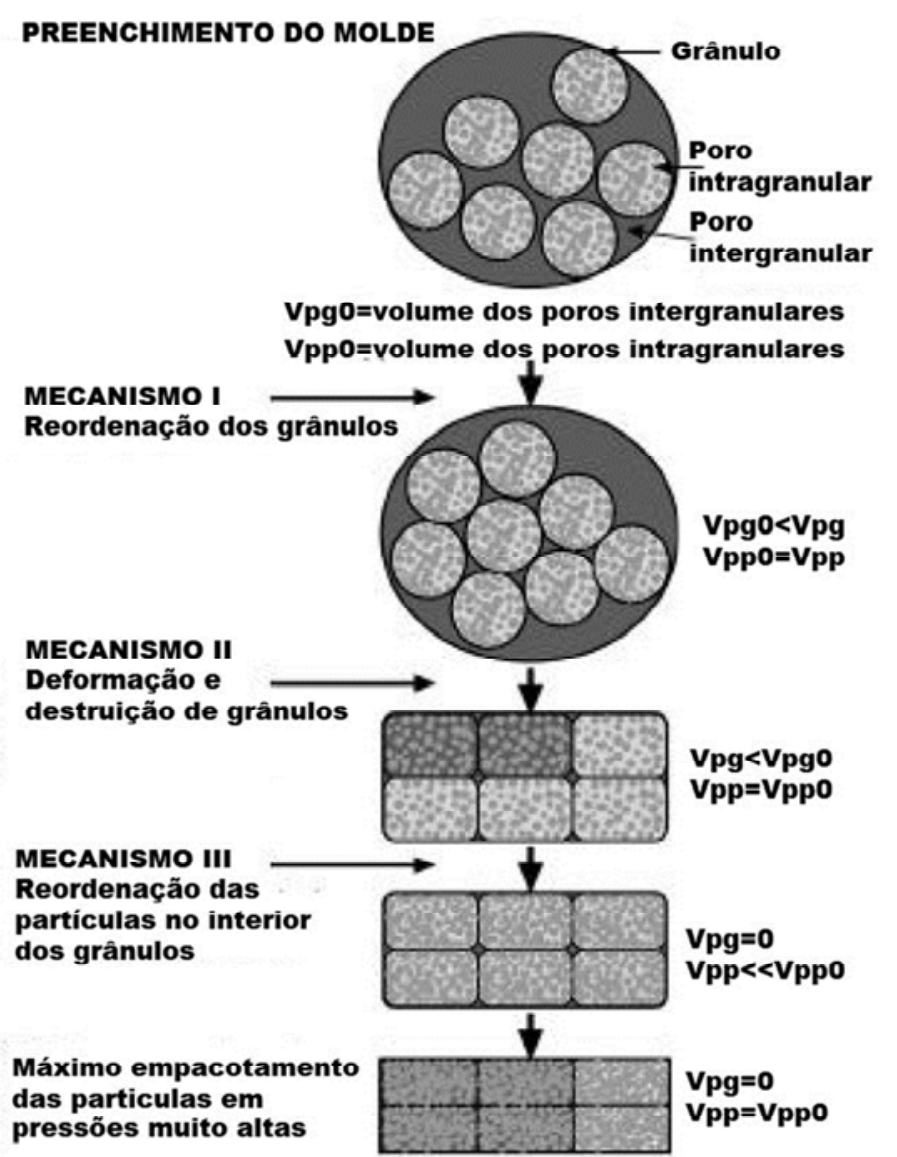

Figura 6 - Mecanismos de compactação (ALBARO, 2000).

Mecanismo I - Redução do volume ocupado pelos poros intergranulares e de seu volume através do deslocamento e reordenação dos grânulos.

Mecanismo II - Redução do volume e tamanho dos espaços intergranulares por deformação plástica e/ou destruição dos grânulos, dependendo das características 
mecânicas do grânulo (dureza, deformabilidade, resistência mecânica). Neste mecanismo se inclui o esmagamento de grânulos ocos, geralmente presentes nas massas cerâmicas.

Mecanismo III - Diminuição de volume e tamanho dos poros intragranulares pelo deslizamento e reordenação das partículas alcançando um empacotamento mais denso.

A destruição e/ou a deformação plástica das partículas que constituem os grânulos, nunca ocorre em extensão apreciável, devido à natureza frágil como a elevada dureza das partículas que constituem os materiais cerâmicos (ALBARO, 2000).

Com base nas mudanças estruturais (volume, tamanho dos poros e compactação) a que é submetido o corpo com o aumento da pressão e levando-se em conta os intervalos de pressão em que predominam em cada um dos mecanismos descritos, a compactação de um material granulado pode ser idealmente dividida em três estágios de compactação Figura 7.

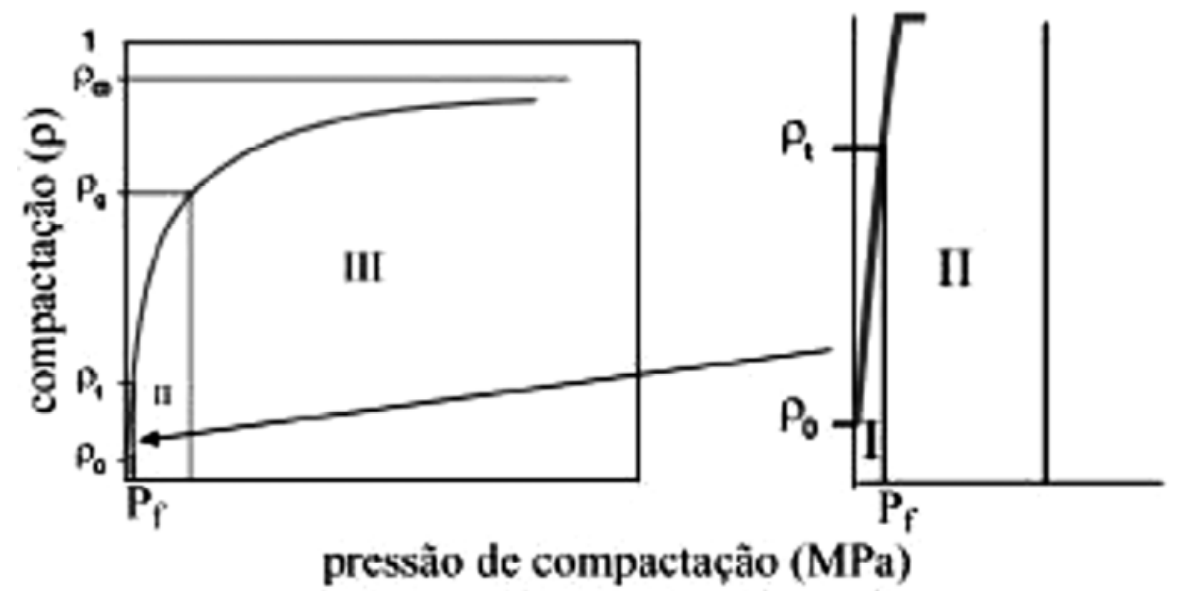

Figura 7 - Variação do grau de compactação do corpo com a pressão de prensagem. Estados de compactação, onde, $\rho D$ densidade de preenchimento do material, Pf pressão aparente de fluência do grânulo, pt densidade de compactação, $\rho$ o até pt estágio de máxima compactação, $\rho \mathrm{g}$ valor de pressão na qual a compactação do corpo coincide com a do grânulo (ALBARO, 2000).

No estágio I ou inicial, a compactação do corpo se considera praticamente a compactação máxima que se pode obter mediante reordenação dos grânulos através da vibração do material (densidade de compactação), pt. O mecanismo de compactação predominante neste estado é o de deslizamento e reordenação dos grânulos. Apesar do efeito da pressão sobre a densificação da peça (dependendo da curva) ser o de maior valor em todo o processo, neste estágio só se incrementa ligeiramente a compactação do corpo, desde seu valor inicial, po até pt (ALBARO, 2000).

O estágio II ou intermediário compreende o intervalo de pressões que se estende desde a pressão de fluência (Pf) até o valor de pressão na qual a compactação do corpo coincide com a do grânulo, $\rho G$. A maior parte da compactação que ocorre no corpo durante a etapa de prensagem se dá neste estágio, através da deformação e/ou destruição dos 
aglomerados (mecanismo II). Conforme se aumenta a pressão, aumenta a área de contato entre os grânulos e a estrutura da peça vai se tornando mais homogênea, ainda que se possam identificar claramente alguns grânulos (Figura 8). Paralelamente, ocorre a redução do volume e tamanho dos poros intergranulares. Durante todo o processo a distribuição de tamanho de poros é bimodal (Figura 9) e praticamente toda a redução da porosidade é devida à eliminação da porosidade intergranular. A porosidade intragranular permanece praticamente inalterada (ALBARO, 2000).

Por último, o estágio III ou final se inicia quando o grau de compactação do corpo se iguala ao do grânulo $(\rho G)$. Teoricamente, neste ponto desaparece toda a porosidade inter-granular, e a distribuição de tamanho dos poros é monomodal (Figura 9). Como consequência, neste estágio o aumento da compactação do corpo só pode decorrer da eliminação da porosidade intragranular, através do deslizamento e reordenação das partículas (mecanismo III). Com o aumento da pressão, diminui-se o volume e tamanho dos poros, as interfaces entre os grânulos vão se tornando imperceptíveis e a microestrutura da peça é cada vez mais homogênea (Figura 8). Assim, em pressões elevadas, um aumento na pressão de prensagem pode ocasionalmente provocar a fratura de agregados porosos e/ou a destruição de aglomerados de partículas que tenham resistido a pressões menores, aumentando ligeiramente a compactação do corpo. De uma maneira geral, a maior parte da carga aplicada neste estágio provoca uma compressão elástica do material, que se armazena sob forma de energia elástica, vindo a ser liberada com a retirada da carga (Figura 10).

A compactação final da peça, por mais que se aumente a pressão de prensagem, é sempre inferior à compactação que corresponderia ao empacotamento mais denso possível das partículas. Isto se deve a alguns motivos.

i) a formação de empacotamentos irregulares e porosos de partículas que resistem às altas pressões devido a sua fragilidade e dureza, ainda existindo entre elas altíssimas forças de atrito;

ii) Em altas pressões, que correspondem a baixas porosidades, se o conteúdo de ligantes e plastificantes líquidos é elevado, pode ocorrer saturação dos poros da peça pelos mesmos, impedindo a compactação.

Os intervalos de pressão onde atuam cada um destes mecanismos não estão tão claramente definidos, uma vez que com frequência dois deles se verificam simultaneamente, o fluxo e a reordenação de grânulos podem vir acompanhados da deformação plástica e destruição dos mesmos (superposição dos mecanismos I e II). Da mesma forma, é frequente que o início do processo de redução da porosidade intragranular (mecanismo III) se dê antes da eliminação total da porosidade intergranular através do mecanismo II, tal como pode ser comprovado na Figura 10 (ALBARO, 2000). 


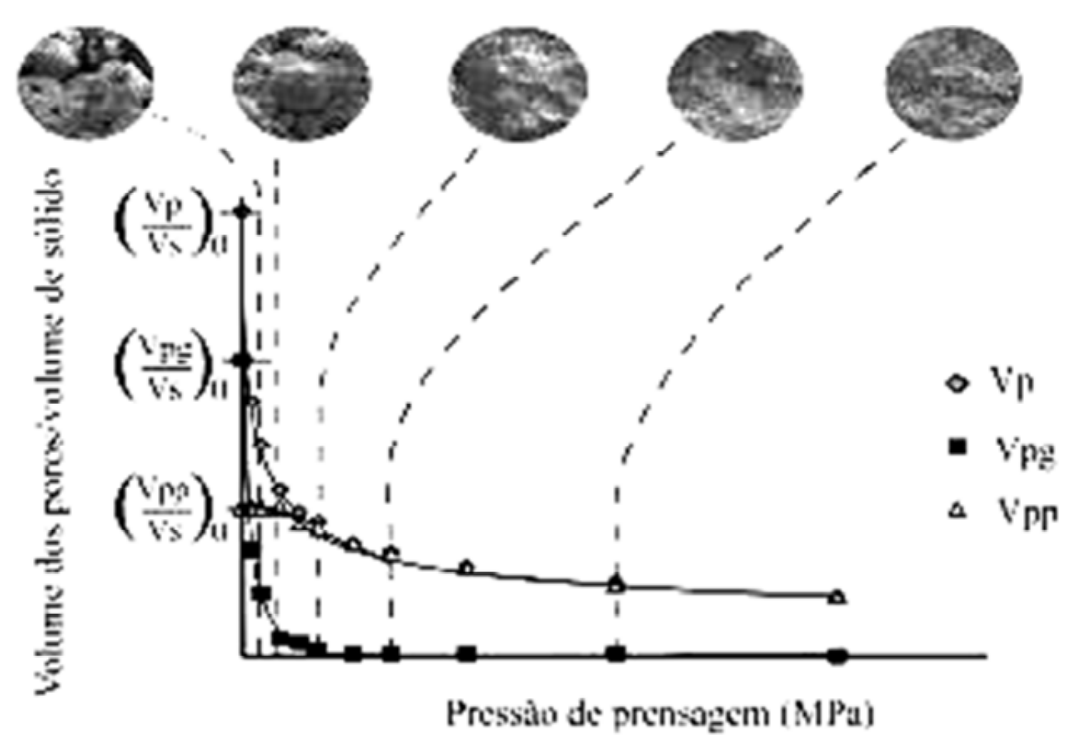

Figura 8 - Variação do volume de poros intragranular $\left(V_{p p}\right)$, intergranular $\left(V_{p g}\right)$ e total $\left(V_{p}\right)$ do corpo em função da pressão de prensagem (ALBARO, 2000).

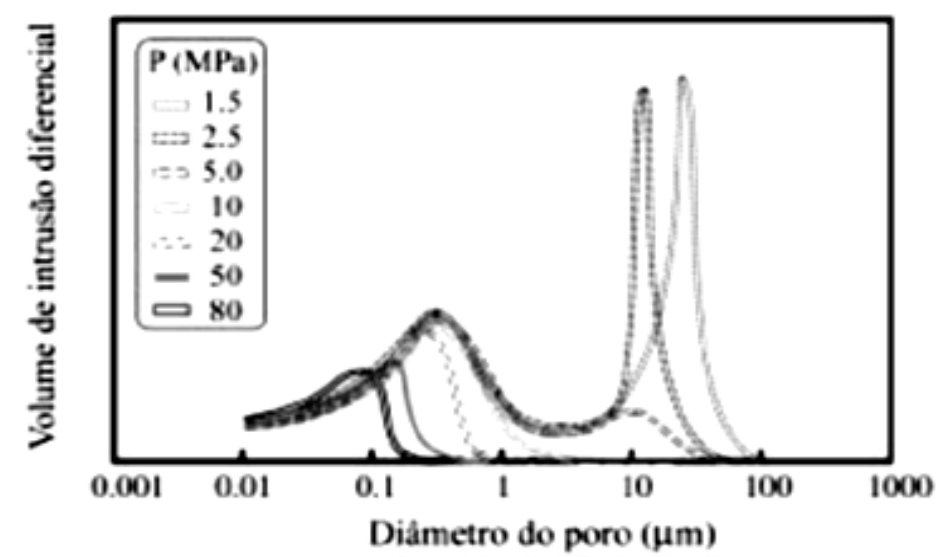

Figura 9 - Variação da distribuição de tamanho de poros do corpo com a pressão de prensagem (P) (ALBARO, 2000).

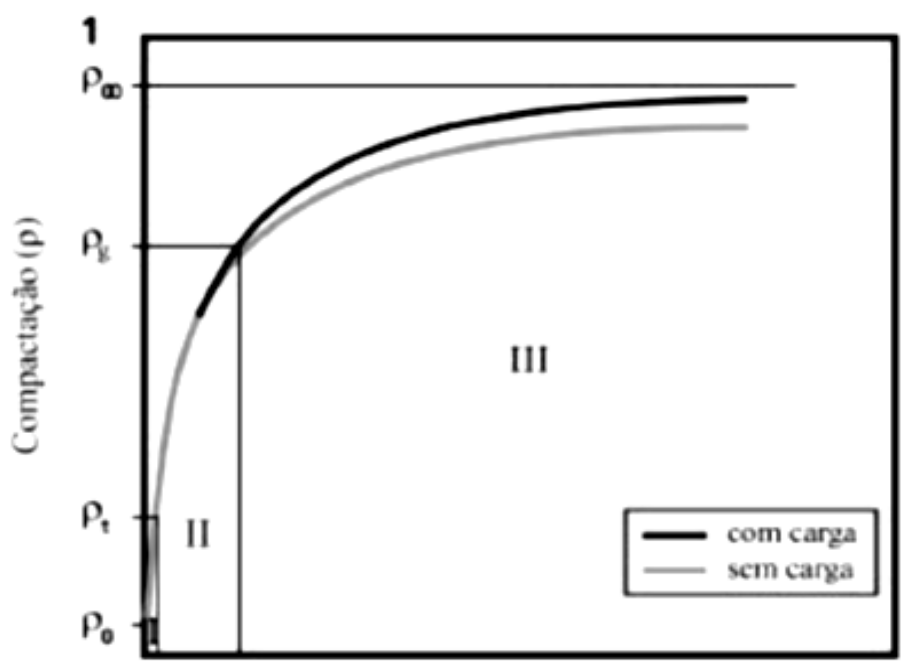

Pressào da prensagem (MPa)

Figura 10 - Variação da compactação do corpo em função da pressão de prensagem (ALBARO, 2000). 


\subsection{Aditivos}

Aditivos são todos os materiais orgânicos ou inorgânicos, adicionados as particulas para melhorar o processamento e manufatura cerâmica tais como: ligantes, lubrificantes, plastificantes e defloculantes, que quando combinados adequadamente aumentam a fluidez, reduzem a resistência ao atrito, melhoram a resistência mecânica, aumentam a lubrificação entre as partículas e entre elas e a parede do molde resultando em um aumento da densidade a verde e da uniformidade final do compactado sem causar efeitos posteriores. Segundo Pandolfelli et al (1981), os aditivos possuem as funções apresentadas na Tabela 1.

Tabela 1 - Funções dos aditivos (PANDOLFELLI et al, 1981).

\begin{tabular}{|l|l|}
\hline Aditivo & Função \\
\hline Ligante & Aumenta a resistência a verde \\
\hline Lubrificante & $\begin{array}{l}\text { Facilita a ejeção do molde e escorregamento entre as } \\
\text { partículas }\end{array}$ \\
\hline Plastificante & $\begin{array}{l}\text { Auxilia a deformação plástica do grânulos, melhorando a } \\
\text { flexibilidade dos filmes ligantes }\end{array}$ \\
\hline Defloculante & $\begin{array}{l}\text { Permite a dispersão e } \\
\text { controla a carga superficial das partículas. }\end{array}$ \\
\hline Agente molhador & Abaixa a tensão superficial do líquido \\
\hline Agente redutor de água & Evita a expulsão da água durante a aplicação de pressão \\
\hline Agente antiestático & Controla a carga eletrostática das partículas \\
\hline $\begin{array}{l}\text { Agente } \\
\text { anti-espumante }\end{array}$ & Evita a formação de espuma \\
\hline Agente sequestrante & Torna inativo os íons indesejáveis \\
\hline Fungicida & $\begin{array}{l}\text { Estabiliza a degradação devida ao envelhecimento e/ou } \\
\text { microrganismos. }\end{array}$ \\
\hline
\end{tabular}

Os aditivos ligantes são identificados em dois tipos principais: os soluveis em meio aquoso tais como o PVAL e resinas acrilicas solúveis em meios alcoolicos como o PVB.

\subsubsection{Poli (álcool vinilico) - PVAL}

O Poli (álcool vinílico) (PVAL) é produzido pela hidrólise do poli (acetato de vinila) (PVAc), uma vez que o monômero álcool vinilíco não existe no estado livre.

O PVAL é um polímero semicristalino, sendo que seu grau de cristalinidade esta associado ao grau de hidrólise e à história térmica. O grau de cristalinidade, por sua vez, influencia a solubilidade, a sensibilidade a água, o módulo de tração, as propriedades de transporte relativas ao oxigênio, e as propriedades térmicas desse polímero.

A temperatura de fusão cristalina ( $\mathrm{Tm}$ ) depende da perfeição e do tamanho dos cristais, variando de 220 a $267^{\circ} \mathrm{C}$, no caso do PVAL completamente hidrolisado. A determinação exata da Tm através de técnicas, como o DSC, é dificultada pela 
decomposição do material, que se decompõe rapidamente acima de $200^{\circ} \mathrm{C}$ (MARTEN, 1988).

O PVAL completamente hidrolisado de alta massa molar apresenta temperatura de transição vítrea $(\mathrm{Tg})$ a aproximadamente $85^{\circ} \mathrm{C}$, enquanto que em materiais com menor grau de hidrólise, 87 a $89 \%$ hidrolisados, este valor pode estar em torno de $58^{\circ} \mathrm{C}$ (MARTEN, 1988).

O PVAL é solúvel em solventes altamente polares e hidrofilicos, tais como água, dimetilsulfóxido (DMSO) e dimetilformamida (DMF), A solubilidade em água depende do grau de polimerização e do grau de hidrólise. Os grupos hidroxila presentes no PVAL propiciam a formação de pontes de hidrogênio intra e intermoleculares, o que causa a cristalização desse polimero e portanto reduz sua solubilidade em água. Os grupos acetato residuais presentes no PVAL parcialmente hidrolisado, concorrem com grupos hidroxila na formação de ligações por pontes de hidrogênio, interferindo na cristalização das cadeias de PVAL e, portanto diminuindo o grau de cristalinidade e aumentando a solubilidade desses materiais (MARTEN, 1988).

A excelente resistência química e as propriedades fisicas do PVAL têm estendido amplamente seu uso industrial. Este polímero é um excelente adesivo, sendo que sua resistência a solventes, óleos e graxas, é igualada por poucos polímeros. Apresenta ótimas propriedades como agente emulsificante devido a sua baixa tensão superficial.

\subsubsection{Secagem}

Um dos processos mais eficientes usados na indústria de cerâmicas para secagem de pós é o "Spray-Dryer". A técnica consiste em atomizar a suspensão de pó cerâmico recém-moído em uma atmosfera de ar quente e seco. Com a atomização a área superficial do material aumenta facilitando a evaporação do líquido. O pó cerâmico se deposita no fundo da lâmina de secagem. Para atomizar a suspensão podem-se adotar dois tipos de atomizador: o rotativo que fica instalado na parte superior da camara e o de bico que gera um spray de baixo para cima Figura 11 (MASTERS, 1994). 


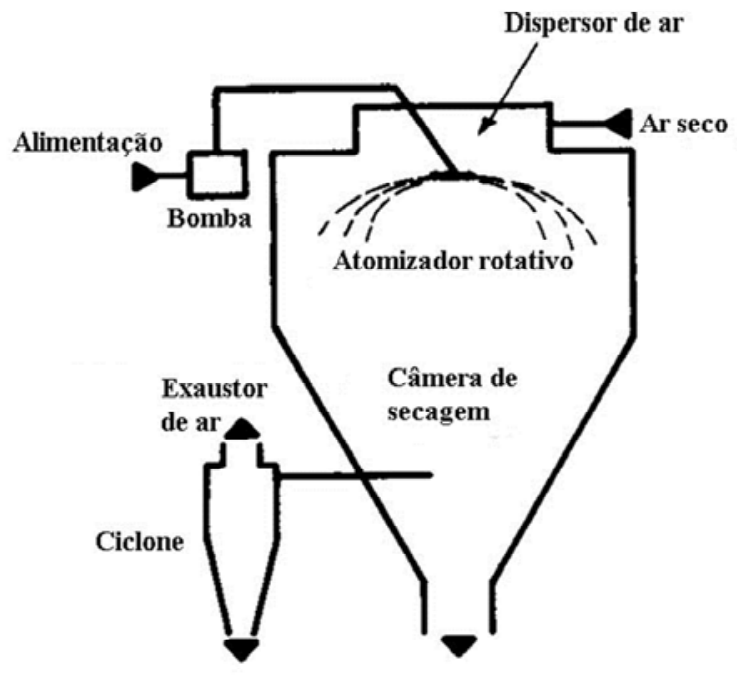

Produto

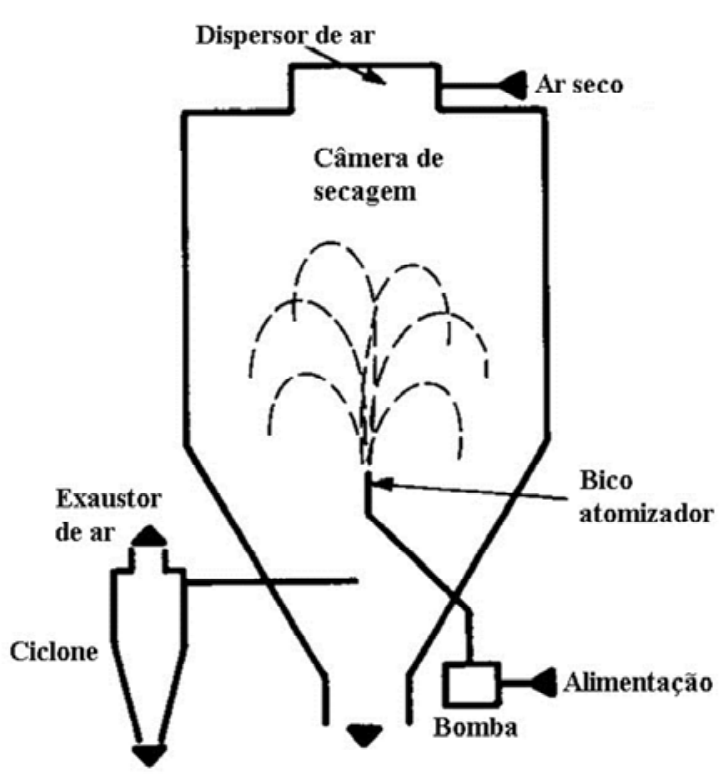

Produto

a) Co-current (Rotativo)

b) Mixed Flow (Bico)

Figura 11 - Esquema do processo de spray-drying para aglomeração de pós-esféricos contendo um nível uniforme de aditivos, em (a) rotativo e em (b) bico, adaptado (RICHERSON, 1992).

\subsection{USINAGEM CERÂMICA}

O processo de usinagem é utilizado para obter a precisão dimensional e forma dos corpos cerâmicos. A usinagem cerâmica pode ser dividida em duas categorias a usinagem a verde e a usinagem após sinterização.

No estado à verde, a fragilidade do componente cerâmico dificulta sua usinagem e após a sinterização, a extrema dureza associada à fragilidade tornam o processo de remoção de material por abrasão lento, sendo necessária a utilização de pequenas profundidades de corte para que os defeitos introduzidos pelo processo sejam minimizados. A forma, o acabamento e a resistência mecânica, em componentes de alta precisão, não podem ser obtidos sem os processos de lapidação e polimento. Porem estas técnicas apresentam dificuldades no controle do processo (WREGE, 2000).

A usinagem a verde é aplicada aos produtos compactados antes da sinterização e usinagem à branco após uma pré-queima (60 - 70\% da temperatura de sinterização). Neste estado, o corpo cerâmico se encontra com as partículas apenas agregadas. Na usinagem após sinterização o método de predominante é o da retificação com rebolos diamantados. Este processo é responsável por $80 \%$ da usinagem após sinterização e apresenta como principais limitações o alto custo (em torno de $90 \%$ do custo total do produto) e a baixa rigidez das retificadoras comerciais e a possibilidade da formação de defeitos superficiais e 
nas subcamadas da superfície que comprometem o desempenho do produto cerâmico diminuindo significativamente sua resistência mecânica e o módulo de Weibull (XU; JAHANMIR, 1994; ALLOR; JAHANMIR, 1996).

\subsubsection{Usinagem à Verde}

É realizada a usinagem a verde com objetivo de reduzir o alto custo associado com a usinagem de cerâmicas avançadas sinterizadas. No caso de lotes pequenos ou quando há uma diversa variedade de partes, a usinagem a verde proporciona uma vantagem considerável em termos de qualidade, eficiência econômica e flexibilidade. Entretanto, ela é usada largamente na indústria, o know-how das companhias é baseado principalmente em dados empíricos, após analisar a influência de vários fatores tais como as ferramentas de corte, parâmetros de processo, geometria das ferramentas, e materiais das ferramentas (KLOCKE; GERENT; SCHIPPERS, 1997).

Estudos mostram a influência da pressão de compactação na qualidade da usinagem à verde, com o aumento da pressão de compactação, o mecanismo de remoção de material atravessa a fase inicial de fratura ao intra-aglomerado para uma fase mista e subsequente fase inter-aglomerado, onde se verifica maiores danos superficiais (KAMBOJ et al, 2003). Este aspecto demonstra a necessidade de estudar os efeitos das variáveis da conformação (umidade da matéria prima, pressão de compactação e tempo) em função das variáveis de remoção de material durante a usinagem.

A quase inexistência de técnicas de usinagem convencional de materiais cerâmicos é devida a elevada dureza e fragilidade que apresentam após a sinterização. Por esse motivo a usinagem convencional da peça verde, em muitos casos, é utilizada. Ocorre, porém que as peças são muito delicadas e não apresentam resistência suficiente para serem usinadas. Para solucionar esse problema, reforça-se o material cerâmico a verde com ligantes poliméricos através de técnicas de impregnação, ou pela adição deles durante a moagem e mistura (ZORZI et al, 1995; WU \& McANANY, 1995).

O formato e as tolerâncias finais, nem sempre conseguem ser obtidas através de moldes. Em muitos casos, as dimensões finais são conseguidas pela usinagem da superfície ou outras operações de acabamento posterior a densificação, isto exige que o trabalho seja feito com ferramentas de diamante. Para minimizar a usinagem póssinterização, usina a massa cerâmica conformada (Blank, corpo compacto branco assim chamado), levando em consideração uma contração de aproximadamente $10 \%$ do volume na densificação, obtendo resultados bem próximos das dimensões finais desejadas, tal processo é referido como à usinagem a verde (Green Machine). A usinagem abrasiva de acabamento eficiente requer o cuidado com quatro tipos de variáveis, a saber: a máquina- 
ferramenta, o rebolo, as propriedades do material da peça e as condições de usinagem (RICHERSON, 1992).

Zipse, 1997 recomenda que o gradiente de densidade não seja superior a 1\%mm, pois na sinterização ocorrerá tensões residuais devido a distorções que podem introduzir defeitos críticos na peça. Bukvic, 2011 propõe a usinagem a verde para além de melhoria no formato, também para a redução do gradiente de densidade que ocorre com maior intensidade nas proximidades da superfície.

O material a verde cerâmico é relativamente frágil, e um grande cuidado é necessário no projeto e na fabricação, o trabalho de usinagem é feito com ferramentas abrasivas, geralmente rebolos, a peça deve ser fixada com muita rigidez, mas sem a concentração de distorções ou de esforços, com baixo nível de vibrações, sistema de remoção do cavaco, precisão de movimentos e posicionamentos, balanceamento dinâmico durante o processo, possibilidade de dressagem e capacidade CNC, para ganhar a forma através de varias operações de desbaste. Todo o processo deve ser controlado para evitar fadiga no material e não produzir microfissuras, rachaduras, ruptura, ou defeitos na superfície. O Green Machine pode ser conduzido por uma variedade de métodos, retifica, perfuração, rebolos com formatos pré-definidos entre outros. É possível usinar corpos conformados com as ferramentas de corte de aço rápido ou de carboneto de tungstênio, mas este não é recomendado para componentes a verde (RICHERSON, 1992).

Devido a baixa resistência mecânica do Blank a verde (8,0 MPa-compressivo), alguns parâmetros de usinagem devem ser determinados para que o processo ocorra sem o risco de danificar estruturalmente a peça a ser trabalhada pela introdução de defeitos críticos (Figura 12).

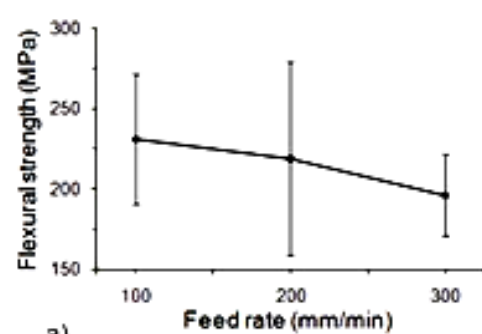

a)

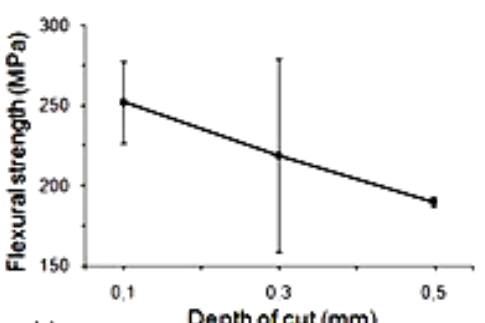

b)

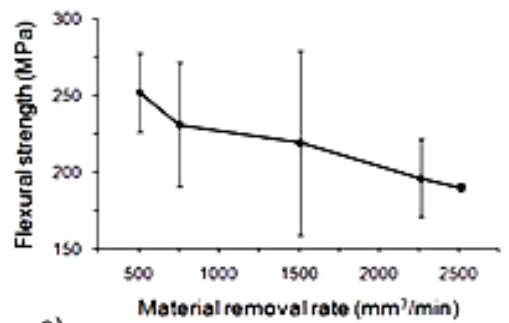

c)

Figura 12 - Resistência à flexão X Parâmetros de corte (FORTULAN, 2011).

Uma das melhores soluções para facilitar a usinagem a verde é a seleção adequada de ligantes da mistura cerâmica para prover resistência suficiente para a peça.

A resistência a verde é controlada pelas interações existentes entre polímeropolímero ou polímero-cerâmica conforme ilustra a Figura 13. Os ligantes constituídos de grupos ácido carboxílicos, tais como o acrílico, são os que têm interações mais fortes com o pó cerâmico. A troca de hidrogênio destes grupos também resulta em fortes interações polímero-polímero. Em algumas misturas é necessária a utilização de um plastificante, como 
por exemplo, a água. Todavia a água age sobre as interações provocando diminuição na resistência mecânica da peça à verde. Por outro lado a peça não pode ter alta resistência a verde, pois isto levaria a fragilidade do material.

A
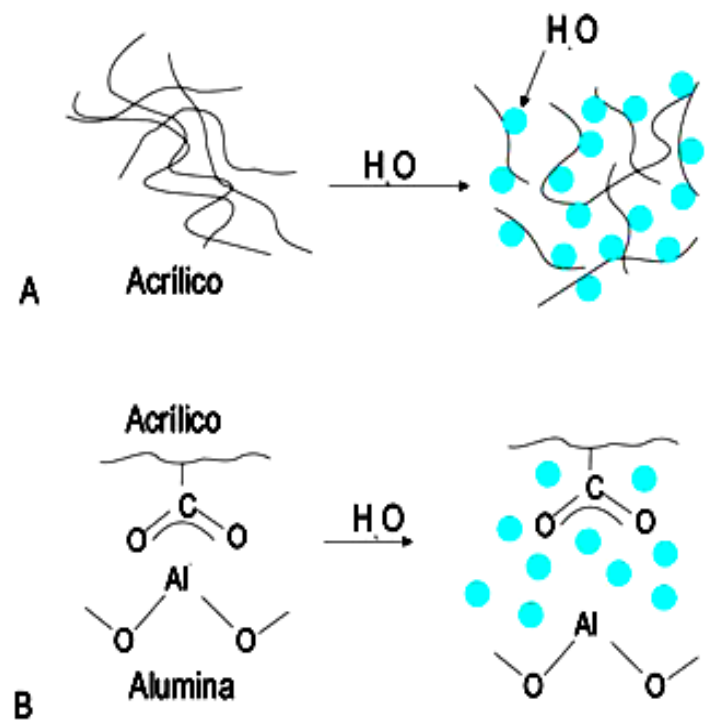

Figura 13 - (A) Redução das interações polímero-polímero e polímero cerâmico com a adição de água. (B) Redução da interação polímero-cerâmica com a adição de água (WU \& McANANY, 1995) apud (REGIANE, 2000).

Outra possibilidade viável é fazer à usinagem a branco (White Machine), o Blank é parcialmente sinterizado, em torno de $70 \%$ da temperatura de sinterização. A compressão isostática assegura que o Blank consiga um nível elevado da densidade e homogeneidade, é uma operação de formação particular apropriada em que a resistência a verde é determinada pelo estabilizador orgânico (composição e quantidade) e pelo ciclo de pressão (nível da pressão, parada, e função da pressão). Os gradientes de baixa densidade na parte verde garantem um baixo nível de tensão residual na parte não sinterizada e, consequentemente, menos distorção após a sinterização. Desde que o pó esteja relativamente seco e a retração total é menor do que nas peças que se submeteram a outras operações de deformação. Dependendo da temperatura durante o estágio parcial da sinterização, o Blank pode alcançar vários graus de tensão acima da tensão a verde, assim facilitando a manipulação das peças. Neste estágio o Blank parcialmente aglomerado está livre de materiais orgânicos e com retração de $2 \%$, e não há nenhum crescimento de grão.

A usinagem de Blanks a verde tem um comportamento diferente dos em branco (pré-sinterizados). Ao fazer à usinagem a branco (pré-sinterizada), ocorrem micro rachaduras por um processo de fratura frágil. Em corpos a verde, devido ao vinculo orgânico com as particulas, o processo de remoção de material é caracterizado mais pela formação de microplaquetas dúcteis do que pela fratura frágil, o que possibilita a produção de superfícies livres de lascamentos, a rugosidade é caracterizada somente pelos sulcos formados pela remoção dos grãos. A qualidade superficial deteriora-se com o aumento do 
avanço (Figura 14). Para que o processo de corte seja eficiente e produza uma qualidade uniforme, a taxa de remoção de material pode ser aumentada através do aumento da profundidade e velocidade de corte (Figura 15). Segundo Jahanmir, não há nenhuma evidência que a profundidade de corte exerce alguma influência na qualidade de superfície.

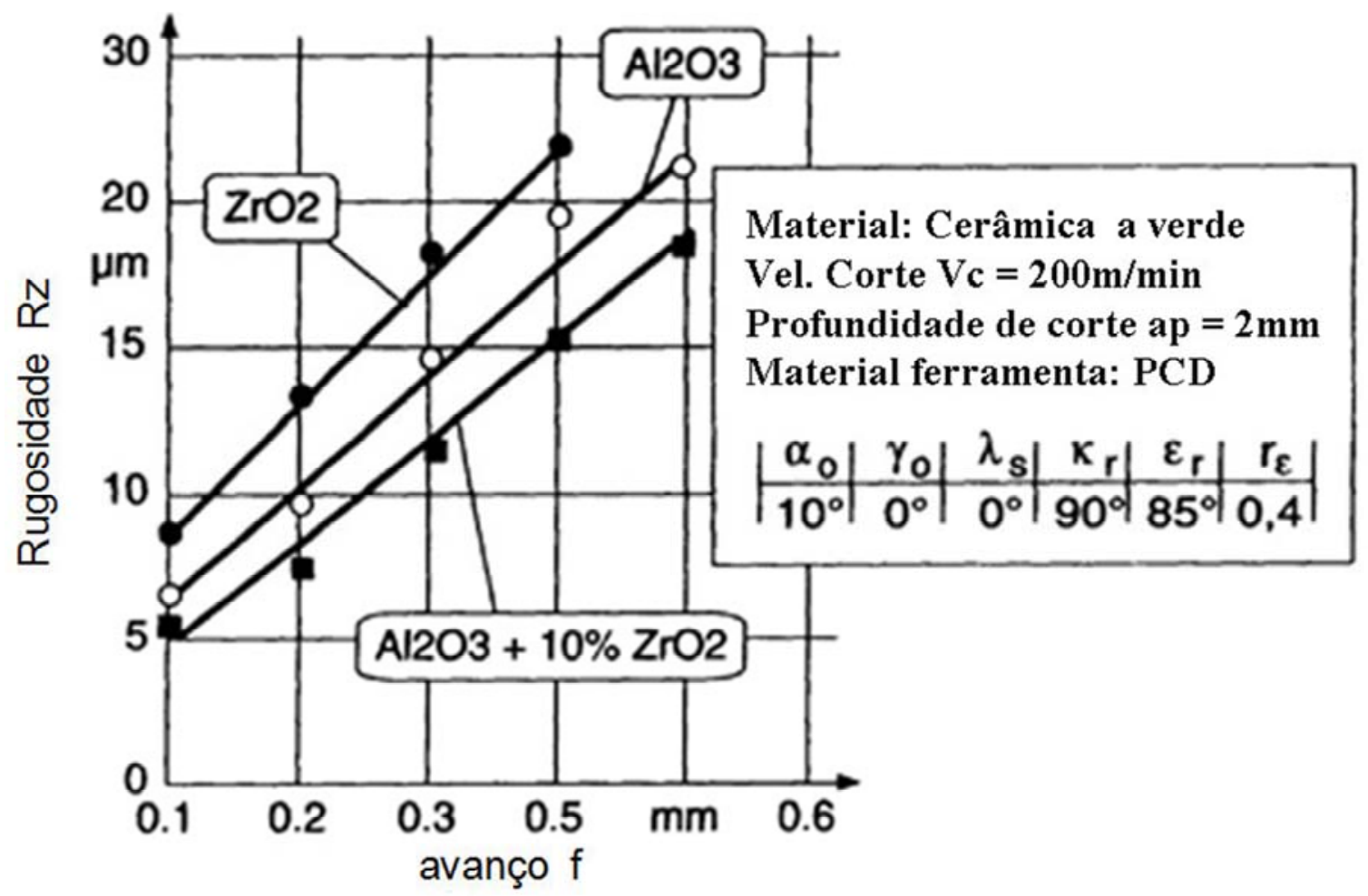

Figura 14 - Influência do avanço (f) em operação de torneamento em oxido de cerâmica a verde (JAHANMIR, 1996).

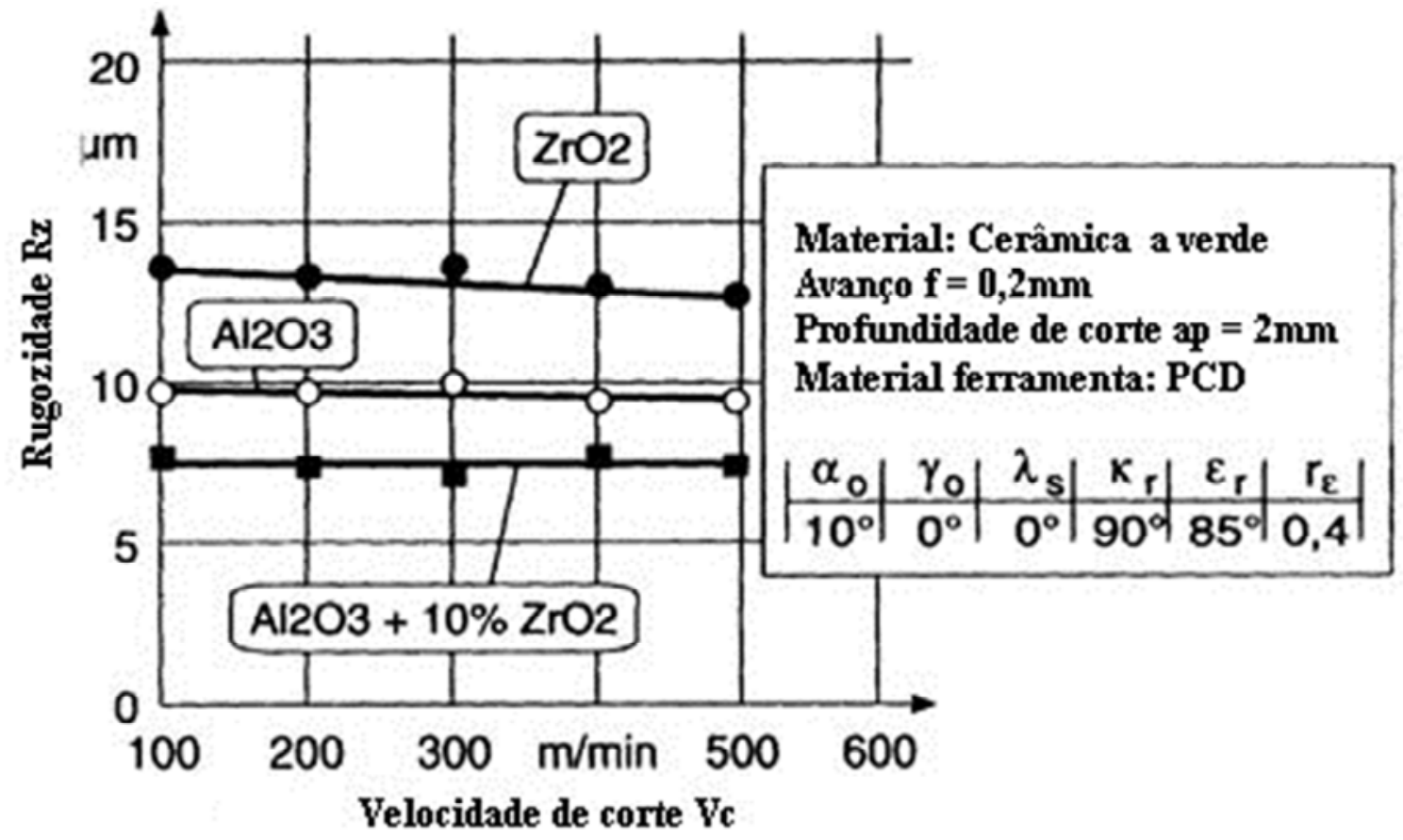

Figura 15 - Influência da velocidade de corte $\left(v_{c}\right)$ em operação de torneamento em cerâmica a verde (JAHANMIR, 1996). 
Segundo Jahanmir 1996, a velocidade do corte, entretanto, tem quase nenhuma influência na qualidade de superfície da cerâmica a verde (Figura 15). O tempo de usinagem, consequentemente, pode ser reduzido aumentando a velocidade de corte, sem incorrer nenhum risco de danificar a qualidade da superfície. Outra vantagem de aumentar a velocidade de corte é a redução do desgaste da ferramenta. Isto pode inteiramente ser explorado em operações de retifica e é limitado somente pela velocidade disponível máxima do eixo. Entretanto, devido às limitações impostas pela resistência do material e os esforços impostos por aumento das forças centrífugas, a velocidade de corte não podem ser aumentada até o infinito em operações de torneamento.

\subsubsection{Equipamentos - Usinagem por retificação}

Máquinas convencionais de usinagem podem ser aplicadas para usinagem à verde. Em máquinas rotativas, a peça é fixada em um eixo e a superfície de contato pressionada contra uma afiada e densa ferramenta de corte ou um rebolo perfilado (Figura 16). Incluem tornos verticais e horizontais, furadeiras, mandriladoras e serras de fita e retificadoras. As velocidades de usinagem variam dependendo da força e da porosidade da matéria-prima e da profundidade de corte. A coleta dos pós de usinagem é essencial neste processo, máquina e operadores devem estar protegidos da poeira abrasiva. A coleta do pó é, também, necessária para manter tolerâncias estreitas $( \pm 0,0125 \mathrm{~mm})$. Sistemas fechados são comumente utilizados para usinagem em alta velocidade (REED,1995).

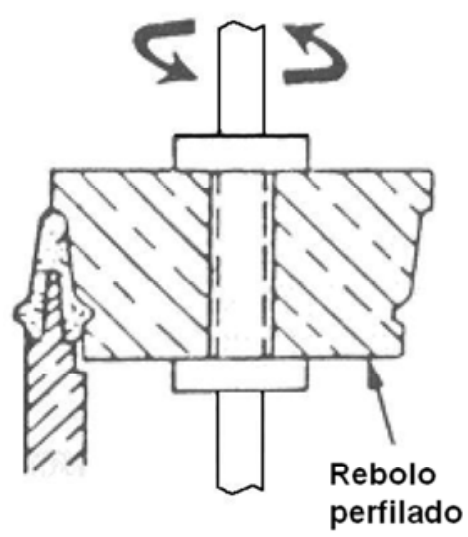

Figura 16 - Retificação de uma cerâmica verde em uma retífica vertical (REED,1995).

Retificação é o processo de usinagem por abrasão o qual remove material da peça através da ação de grãos abrasivos espalhados aleatoriamente pela superfície do rebolo. Ao contrário dos demais processos de usinagem com remoção de material, como por exemplo, os processos de torneamento e fresamento, no processo de retificação a ferramenta, 
chamada de rebolo, apresenta geometria indefinida, ou seja, os grãos abrasivos que constituem o rebolo não apresentam o mesmo posicionamento e a mesma orientação.

De acordo com Werner \& Tawakoli (1989), para se realizar uma operação de retificação com alta velocidade de corte a máquina deve apresentar alguns requisitos básicos:

- $\quad$ Eixo com alta potência;

- Mancais e suportes rígidos;

- $\quad$ Comando CNC;

- $\quad$ Mesas e guias com alta rigidez;

- $\quad$ Sistema de refrigeração otimizado;

- $\quad$ Sistema de balanceamento de rebolo integrado;

- $\quad$ Sistema de dressagem com alta rigidez.

A velocidade periférica do rebolo $\left(v_{s}\right)$ é a principal variável a ser considerada na retificação com rebolos. O aumento da velocidade (Vs) proporciona a variação de diversos parâmetros teóricos de retificação. Entre esses fatores, os parâmetros mais importantes são os relacionados com a geometria do cavaco indeformado, principalmente a espessura do cavaco indeformado $\left(\mathrm{h}_{\mathrm{m}}\right)$.

(a) Espessura do cavaco indeformado $\left(h_{m}\right)$

Também chamada de profundidade de corte de cada grão abrasivo, expressa a máxima profundidade de corte alcançada por um único grão abrasivo dentro da zona de contato do rebolo e da peça. A espessura do cavaco indeformado $\left(h_{m}\right)$ pode ser expressa por

$h_{m}=2 L\left(\frac{V_{w}}{V_{s}}\right)\left(\frac{a p}{d_{e}}\right)^{\frac{1}{2}}$

onde:

L - Espaçamento entre dois grãos abrasivos ativos consecutivos;

$\mathrm{V}_{\mathrm{w}}$ - Velocidade periférica da peça;

$a_{p}$ - Profundidade de corte;

de - Diâmetro equivalente, que na retificação cilíndrica externa é expresso por:

$d e=\frac{d s}{1+\frac{d s}{d w}}$

sendo, $d s$ o diâmetro externo do rebolo e $d_{w}$ o diâmetro externo da peça.

Com o aumento da velocidade Vs ocorre uma redução da espessura do cavaco indeformado, ou seja, ocorre uma redução da profundidade de corte por grão abrasivo (Tonshoff \& Falkenberg, 1996). Com isso, é possível aumentar a velocidade de avanço ( $f$ ), a fim de manter constante a espessura do cavaco indeformado. Segundo Yui \& Lee (1996), a 
principal consequência desse fenômeno é a redução das forças normal e tangencial de retificação.

Além da redução das forcas normal $(F n)$ e tangencial de retificação $(F t)$, o aumento da velocidade de avanço ( $f$ ) possibilita a redução do tempo de retificação para o mesmo volume de material, aumentando assim a taxa de remoção de material (Qw), ampliando o potencial de redução do custo do processo de retificação.

O aumento da velocidade periférica do rebolo também influencia na qualidade da peça retificada, principalmente na rugosidade e nas tensões residuais. Outra grandeza também influenciada pelo aumento da velocidade é a potência consumida. A potência total consumida é composta pela potência de corte $(P C)$ e pela perda de potência $\left(P_{l}\right)$

$$
P_{\text {Total }}=P_{c}+P_{1}
$$

Por definição, a potência de corte $P c$ é expressa pelo produto da força tangencial de retificação $(F t)$ e a velocidade periférica do rebolo $\left(v_{s}\right)$, conforme equação 4.

$$
P_{c}=F_{t} \cdot v_{s}
$$

A perda de potência $\left(P_{l}\right)$ por sua vez, é composta pela potência necessária para rotacionar o rebolo em vazio $\left(P_{L}\right)$, pela potência perdida devido ao contato do fluído de corte sobre a superfície do rebolo (Pkss) que no caso da usinagem a verde pode ser negligenciada, e pela potência perdida devido ao sistema de jato de limpeza da superfície do rebolo (Pssp).

$$
P_{I}=P_{L}+P_{K S S}+P_{S S P}
$$

Todavia o aumento da velocidade (Vs) apresenta maior influência na potência perdida $(\mathrm{PI})$ do que na potência de corte $(P C)$ para valores de Vs acima de $220 \mathrm{~m} / \mathrm{s}$. Isso demonstra que o aumento de $v_{s}$, resulta em um maior aumento na potência perdida para a rotação do rebolo, refrigeração e limpeza do rebolo, do que aumento efetivo da potência de corte PC.

O controle dos esforços na usinagem pode ser implementado na otimização do processo. Através de estudos experimentais foi observada a correlação entre a agressividade do corte e da resistência mecânica do corpo com relação ao torque com o modelo para os esforços de corte resultado (GAMBALE et. al, 2008).

Modelo de forças envolvidas no corte, Figura 17.

$F=$ Resultante de todas as forças,

$\mathrm{Fc}=$ Força Tangencial, $\mathrm{Ff}=$ Força Axial, $\mathrm{Fp}=$ Força Radial 


\section{$F=F_{c}+F_{f}+F_{p}$ \\ $F_{p}>F_{c}>F_{f}$}

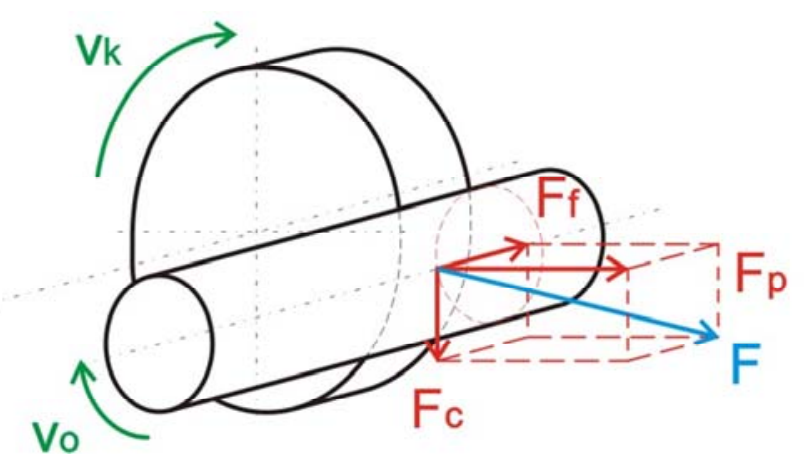

Figura 17 - Forças de corte envolvidas na usinagem com rebolo abrasivo (GAMBALE et. al, 2008).

\subsubsection{Modelos de remoção de material}

O mecanismo de remoção de material é geralmente classificado em duas categorias: fratura frágil e deformação plástica ou dúctil. A fratura frágil, análoga á identação de materiais frágeis por identadores duros, apresenta dois sistemas principais de trincas: trincas laterais que são responsáveis pela remoção de material, e trincas profundas, que reduzem a resistência do material. Na fratura frágil, a remoção de material é acompanhada de nucleação e propagação de trincas, cavacos ou riscos. A deformação plástica ou dúctil, por outro lado, é similar ao processo de formação de cavaco em retificação de metais, que envolve riscamento e formação do cavaco, O material é removido na forma de cavacos severamente cisalhados. A resistência mecânica, a dureza, a tenacidade à fratura e a microestrutura do material são os fatores que controlam o processo de fratura frágil ou deformação plástica. O processo de retificação é um processo de introdução de defeitos desde que o grão abrasivo seja forçado contra a superfície da peça. As operações de retificação causam mudança da resistência mecânica dos componentes, como é frequentemente reportado na literatura.

O termo regime dúctil tem sido usado para descrever o mecanismo de remoção de cavaco contínuo na retificação de cerâmicas avançadas sinterizadas. A hipótese tem avançado juntamente com a tese de que todo material, apesar de sua dureza e fragilidade deve ter uma transição de regime frágil para regime dúctil abaixo de uma dimensão característica da geometria de corte, como por exemplo, a profundidade de corte. Essa hipótese é baseada no consumo de energia dos diferentes mecanismos de remoção de material. A energía requerida para a fratura frágil é proporcional ao quadrado daquela dimensão característica de corte. A energia requerida pela deformação plástica é proporcional ao cubo dessa mesma dimensão característica. Como a ordem de grandeza dessa dimensão característica de usinagem decresce, a deformação plástica torna-se energeticamente favorável como processo de remoção de material; mecanismo de remoção 
de material em dimensões reduzidas, porém baseada no regime dúctil. Apesar deste discurso estar relacionado com cerâmicas sinterizadas, a cerâmica a verde pode ser relacionada igualmente.

A abrasão pode ser considerada como um fenômeno de riscamento múltiplo e que pode ser estudada através de contatos elementares, supondo seus efeitos independentes, utilizando-se de esclerometria. A remoção de um simples grão é causada, provavelmente, por crescimento de trincas ao longo ou muito próximas dos contornos de grãos, resultante das tensões formadas atrás da ferramenta durante o riscamento. Esse mecanismo de remoção de grãos é esquematizado na Figura 18. Note-se que a tensão de tração abaixo da superfície é um fator importante no processo (JAHANMIR, 1996). Uma analogia pode ser proposta para usinagem a verde, porém no lugar do grão tem-se o aglomerado.

a) Aglomerado fácil de remover

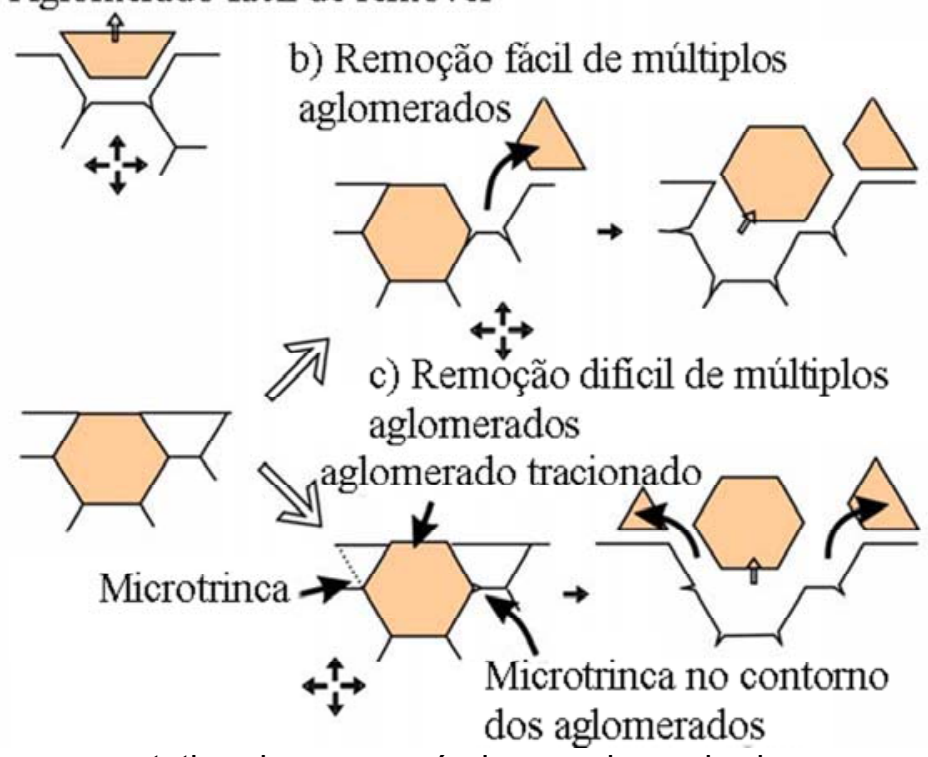

Figura 18 - Esquema representativo de um possível mecanismo de danos ao material. RUFF et al (1995).

Neste modelo a espessura do cavaco varia de zero até a espessura máxima $h_{\max }$ (Figura 19). A formação do cavaco ocorre quando a região de domínio plástico é ultrapassada, ou seja, a espessura do cavaco ultrapassa a espessura crítica $\left(h_{c}\right)$. Dois tipos de remoção de material poderão ocorrer: a formação de cavaco dúctil ou frágil. Os cavacos frágeis apresentam-se na forma de lascas originadas da formação de fraturas. Com o aumento na espessura do cavaco o regime frágil prevalece ao regime dúctil (LAMMER, 1990, MALKIN \& HWANG, 1996). 

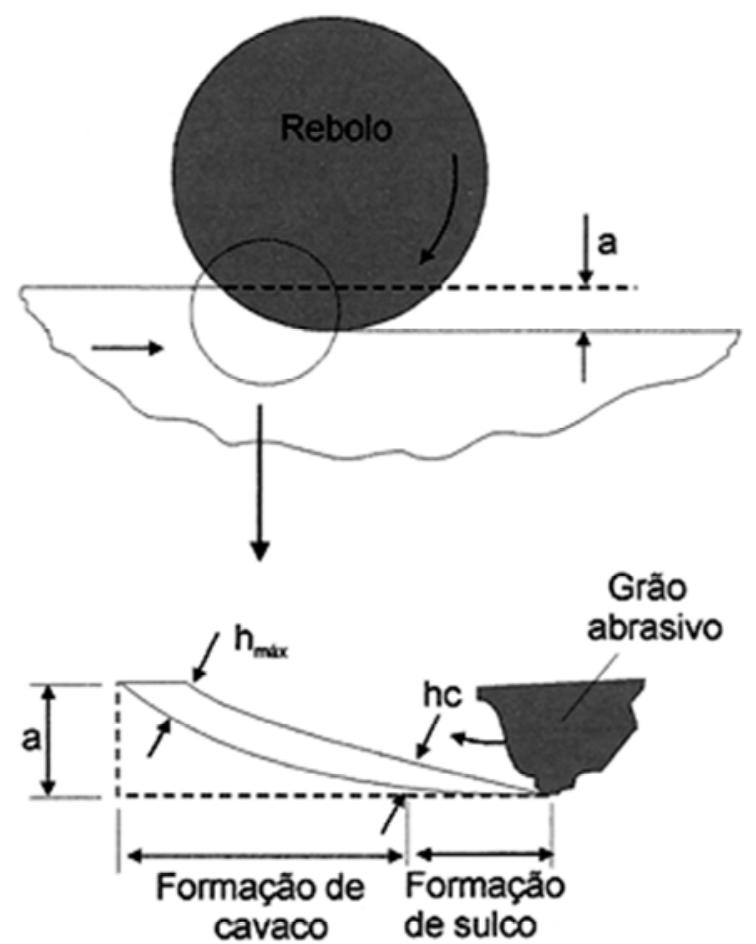

Figura 19 - Modelo de formação teórica do cavaco. (MALKIN \& RITTER, 1989).

De acordo com a Figura 20, a alta rotação reduz a deformação sem a formação de cavaco, diminui a força normal aplicada por cada grão abrasivo e a degradação da resistência mecânica do corpo usinado.

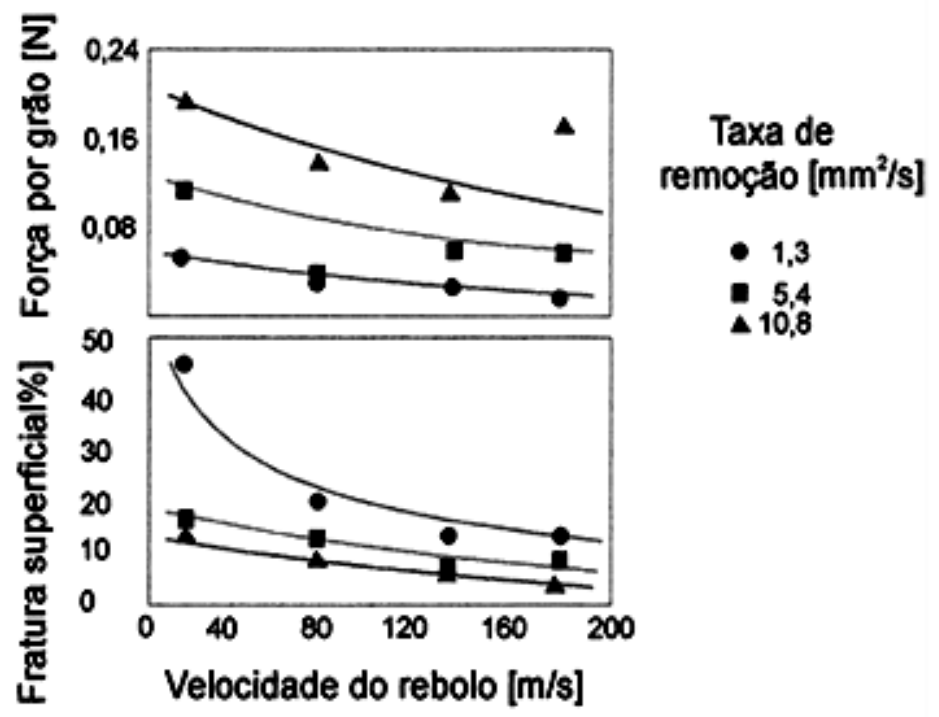

Figura 20 - Efeito da velocidade do rebolo sobre a degradação da resistência mecânica do componente usinado e sobre a força normal aplicada por grão. (MALKIN \& HWANG, 1996).

Há quatro principais mecanismos envolvidos na remoção de material durante a usinagem de cerâmicas verde: a remoção de aglomerados, pulverização, fragmentação e formação ductil de cavacos. No processo de remoção de aglomerados, o material é 
removido pela quebra e remoção de aglomerados da superfície da peça. Este mecanismo é normalmente efetuado em simultâneo com escamação, que é o principal mecanismo de remoção de material em retifica.

No caso de fragmentação, lascas são removidas pela propagação de fendas laterais e radiais que ocorrem durante a usinagem abrasiva. O principal problema é a propagação de fendas profundas, que reduz a resistência mecânica da peça. Pulverização é um modelo de mecanismo que procura explicar a diferença entre a microestrutura na região próxima do risco e na região em massa da peça. De acordo com este mecanismo, durante o contato entre o grão abrasivo e a superfície da peça, os aglomerados na região da superfície são pulverizados com dimensões inferiores a um mícron. A pressão exercida sobre a superfície pela ação dos grãos abrasivos gera calor por atrito.

O mecanismo de remoção de material dúctil, supõe que o material pode ser removido através de um fluxo plástico do ligante sob certas condições de usinagem. Estas condições geralmente estão relacionadas a profundidade de corte.

\subsubsection{Efeito da profundidade de corte na remoção de material e na geração de defeitos}

A utilização de profundidades de corte excessivas gera uma alta força de contato ocasionando a formação de fissuras. Vários defeitos foram observados em peças retificadas com profundidades de corte entre 20 a $30 \mu \mathrm{m}$, grande parte relacionada à presença de tensão residual. Observaram ainda que peças retificadas com profundidade de corte entre 5 à $10 \mu \mathrm{m}$ apresentaram resistência mecânica de 40 à $60 \mathrm{MPa}$ superior às peças simplesmente sinterizadas e as retificadas com profundidade entre 20 à $30 \mu \mathrm{m}$ somente 30 MPa superior. O acréscimo da resistência mecânica é atribuído à redução do tamanho dos defeitos originados na fase de sinterização (TUAN \& KUO, 1998).

\subsubsection{Forças de retificação}

Na retificação, o material é removido por um rebolo em alta rotação, a uma taxa de avanço especial e profundidade de corte ou mergulho. As forças geradas entre o rebolo e a peça estão relacionadas com os parâmetros de usinagem, bem como para as propriedades da peça, tais como dureza e tenacidade. A força total da retifica é composta de forças que atuam sobre as partículas dos grãos abrasivos individuais, que irão deformar e riscar a peça para remover o material da superfície, por uma combinação de formação do Blank, fadiga e processos de fratura. O processo de remoção é determinado pela natureza das partículas abrasivas (forma, tamanho, força, etc), as propriedades da peça (dureza, módulo de elasticidade, tenacidade à fratura, etc), a magnitude das forças de interação entre as partículas e as peças, o tempo de dependência das forças da natureza e do meio ambiente 
(fluido de corte e aparas). A física e a química envolvidas são complexas e só se compreende a partir de modelos extremamente simplificados.

O modelo mais simples de remoção de material por raspagem ou abrasão considera a penetração da ponta de uma única partícula na superfície da peça, por analogia com os tipos de dano (ou seja, deformação plástica e trincas) gerando materiais frágeis. $\mathrm{O}$ processo de remoção de material cerâmico é classificado em um processo de ruptura frágil ou um processo dúctil de deformação plástica. Como a penetração ocorre em um material frágil, o deslocamento elástico é seguido por fluxo plástico e fratura. Fratura é considerada para ocorrer somente após uma carga limite aplicada para a partícula. Para materiais muito frageis o limiar das cargas são muito pequenos. Usinagem em carga, ou por analogia a profundidades de penetração das partículas, inferior ao limite é normalmente referido como regime dúctil em retifica.

Dois modelos básicos têm sido propostos para descrever o processo de remoção frágil de material durante a usinagem abrasiva de cerâmica. O modelo Evans e Marshall baseia-se na formação de fissuras paralelas à superfície de tensões residuais durante a descarga. Além de fendas "laterais", um conjunto de fendas verticais à superfície ou fissuras "médias", são formados próximos a fronteira entre a zona elástica e plástica. Enquanto a extensão das fissuras laterais é assumida como responsável pela remoção de material por desbaste, as rachaduras medianas tambem afetam a força da superfície usinada. O modelo de esmagamento baseia-se na formação e extensão de um grande número de microrachaduras distribuídos em toda a região estressada abaixo do contato. Durante a remoção de material por retifica ocorre predominantemente o processo de microfratura, na maioria das condições, aplicados a nitreto de silício e alumina. A relação entre a força normal de retifica e as propriedades mecânicas da peça, bem como os parâmetros de retifica, é modelada para cada modo de remoção (por exemplo, deformação, microfratura e fratura frágil). Uma das principais consequências da remoção de material por usinagem abrasiva é a geração de danos associados à deformação plástica e fratura.

\subsubsection{Efeitos da retificação associados ao Green Machining}

No estado verde, Blanks de cerâmica são caracterizados por um nível muito inferior de resistência inerente do que as peças sinterizadas, apresentando uma variedade de problemas. Dificuldades surgem não só no âmbito de fixação e movimentação, mas também no que diz respeito à medição da qualidade da superfície. Métodos com contato da medição da superfície não devem ser aplicados, uma vez que o identador pode penetrar e danificar a superfície. Os métodos de medição ópticos sem contato, são os mais adequados para esta aplicação, como aqueles que utilizam um feixe de laser para gravar rugosidades na superfície. 
A natureza abrasiva dos grãos de materiais cerâmicos, não só resultam em um alto nível de desgaste da ferramenta, mas também necessita de modificações no projeto da máquina para permitir a usinagem verde. As baixas forças de usinagem nas operações a verde significa que a máquina-ferramenta não requer o mais alto grau de rigidez, como, por exemplo, em operações de usinagem de metal, onde muito mais esforço é exigido dos barramentos e rolamentos.

Quando Blanks de cerâmica a verde são usinados, os cavacos que normalmente são associadas a operações de usinagem de metais não estão presentes, em vez disso, são produzidos como partículas de poeira. $O$ diâmetro dessas partículas, que se tornam finamente distribuído na máquina-ferramenta, variam de alguns micrômetros a poucos milímetros. Sua remoção do espaço de trabalho é vital para a segurança, o andamento do processo, a finalização da usinagem, e a vida útil da máquina. As partículas podem aderir à superfície da peça, resultando em maior desgaste da ferramenta. O pó, que adere sobre os rolamentos e barramentos, tem um efeito altamente abrasivo e provoca desgaste, afetando negativamente a precisão da máquina e, finalmente, resultando na destruição dos rolamentos e barramentos. Ambas as máquinas-ferramenta e da área circundante devem ser adequadamente protegidas. Medidas primárias e secundárias, tais como aspiração de pó e encapsulamento da máquina são de vital importância neste contexto (JAHANMIR, 1996).

O encapsulamento completo da máquina protege tanto a área de trabalho ao redor e ao operador da máquina. A distribuição das partículas abrasivas, portanto, fica restrita à área interna da unidade. Se possível, as partículas de pó devem ser removidas por um sistema de extração no ponto onde são formados, ou seja, diretamente no ponto de usinagem. Um benefício adicional de encapsulamento completo da máquina ferramenta é a redução na emissão de ruídos. Além disso, a sala onde a máquina-ferramenta está localizada deve ter um sistema de exaustão adequado. $O$ volume da usinagem é um fator importante no projeto da unidade de sucção (JAHANMIR, 1996).

O uso de cortinas ou persianas é um meio eficaz de impedir que partículas de poeira assente sobre os barramentos. Devido ao efeito de sucção do mandril de aperto no torneamento e fresagem, cuidados devem ser tomados para evitar que as partículas entrem no conjunto de rolamentos dos eixos. Podem ser eficazmente protegidos através de uma barreira de ar (por exemplo, ar comprimido). Os mandris comumente usados em aplicações para trabalho de metais, com todas as suas desvantagens em termos de acompanhamento da aplicação da força e da falta de sensibilidade, são freqüentemente utilizados na usinagem de cerâmica verde. É aconselhável que a aplicação da força seja tão plana quanto possível para evitar danos, como rachaduras, fragmentação, ou riscar a peça. A utilização 
de um sistema a vácuo ou a implantação de força elástica, oferecem meios de melhoria (JAHANMIR, 1996).

O conhecimento da usinabilidade de um material, juntamente com máquinas devidamente adaptadas e conceitos de ferramentas, é essencial para as operações de usinagem a verde seja realizada com sucesso. Não se deve esquecer que, devido à alteração dimensional durante a sinterização, uma operação de usinagem final, após a sinterização quando tolerâncias estreitas ou superfícies funcionais são requeridas, ainda é indispensável (JAHANMIR, 1996).

\subsubsection{Ferramentas de Corte}

O projeto e seleção da ferramenta são meios alternativos de influenciar as características do processo. A adaptação de vários materiais de ferramentas de corte para a usinagem a verde em alumina é comparada na Figura 21. Devido à natureza altamente abrasiva dos resíduos e partículas geradas durante a usinagem, existe um alto desgaste para ferramentas cerâmicas e de carbeto de tungstênio. $O$ aumento acentuado no desgaste do carbeto de tungstênio após uma distância de corte de apenas poucos metros é claramente visível, o qual é o fator decisivo para concluir o teste de usinagem. Em contraste, o aumento linear no desgaste mantido pelo PCD e CBN é muito leve. A vida da ferramenta que podem ser alcançadas pelo PCD e CBN, com níveis de desgaste de ferramenta idênticos, são várias vezes maiores do que aquelas do carbeto de tungstênio e da cerâmica.

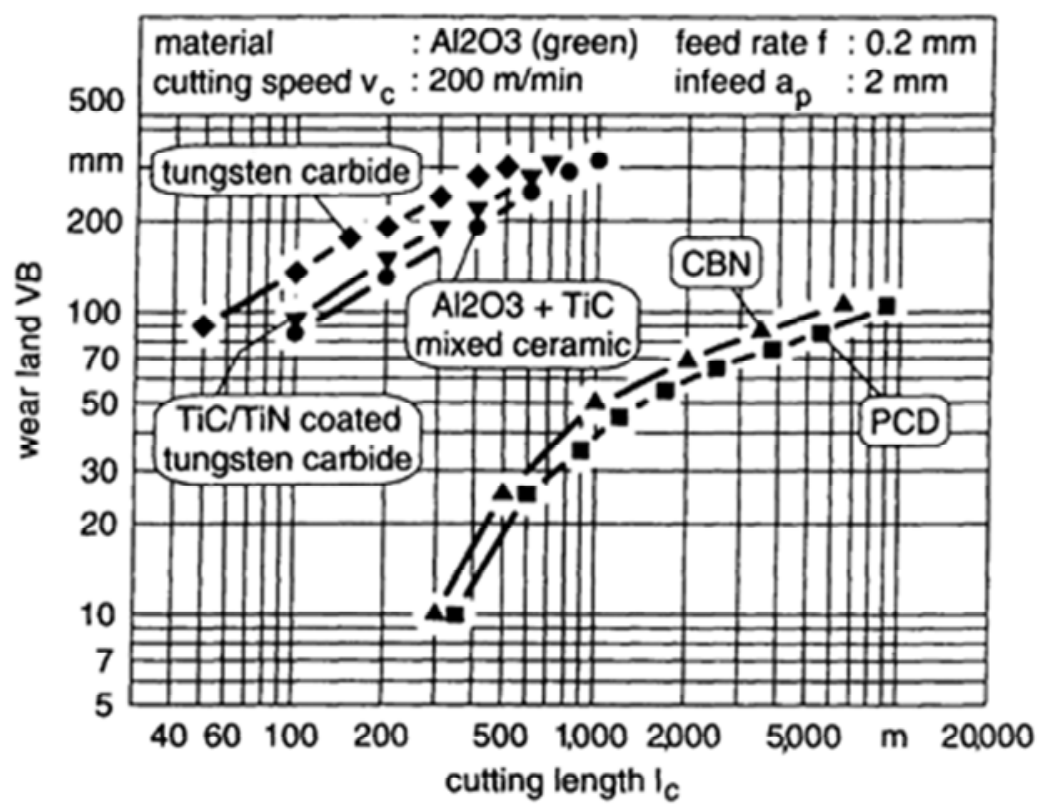

Figura 21 - Comparação do desgaste de ferramenta associado a vários materiais de ferramentas de corte da usinagem a verde de alumina (KLOCKE; GERENT; SCHIPPERS, 1999).

As ferramentas empregadas podem ser de ponta única quando se necessita da máxima flexibilidade no formato da peça e com alta taxa de remoção de material, com 
aresta cortante podendo ser aplicado um formato no perfil da aresta e com múltiplas arestas como no caso do rebolo cerâmico. A resistência da aresta de corte da ferramenta dura é um fator crítico. Um contorno completo pode ser obtido quando uma ferramenta de corte perfilada é utilizada. A ferramenta perfilada pode ser uma pastilha de carbeto de tungstênio.

A seleção do processo de usinagem está diretamente relacionada com a ferramenta de usinagem (Tabela 2). Para ferramentas de ponta única o torneamento e mandrilhamento são associados. Para ferramentas com arestas cortantes pode-se empregar o torneamento, fresamento, furação e o mandrilhamento. Para rebolos o processo associado é o da usinagem abrasiva, a retificação (JAHANMIR, 1996).

Tabela 2 - Propriedades de alguns materiais para ferramentas (JAHANMIR, 1996).

\begin{tabular}{|c|c|c|c|c|}
\hline Material & $\begin{array}{c}\text { Hardness } \\
\text { (Knoop: } \\
\text { GPa, } 100 \mathrm{~g} \text { ) }\end{array}$ & $\begin{array}{l}\text { Hardness } \\
\text { (Vicker, } \\
\text { GPa) }\end{array}$ & $\begin{array}{c}\text { Toughness } \\
K_{\mathrm{A}} \\
\left(\mathrm{MPa} \mathrm{m}^{\prime \prime s}\right)\end{array}$ & $\begin{array}{l}\text { Transverse } \\
\text { rupture } \\
\text { strength } \\
\text { (GPa) }\end{array}$ \\
\hline WC grade $\mathrm{HI}$ & $19-21$ & 18.7 & 6.7 & 2.10 \\
\hline $\mathrm{CBN}$ grade $\mathrm{BN} 200$ & $45-46$ & 30.5 & - & 0.82 \\
\hline CBN grade $B N 250$ & - & 33.0 & - & 1.00 \\
\hline PCD $0.5 \mu \mathrm{m}$ grain & $80-85$ & $80-100$ & - & 2.20 \\
\hline PCD $5 \mu \mathrm{m}$ grain & - & $100-120$ & - & 2.00 \\
\hline PCD $50 \mu \mathrm{m}$ grain & - & $100-120$ & - & 1.10 \\
\hline $\mathrm{B}_{+} \mathrm{C}$ & $29-31$ & 37.0 & - & - \\
\hline $\mathrm{SiC}$ & $21.5-29.5$ & - & 4.60 & - \\
\hline $\mathrm{Al}_{2} \mathrm{O}_{3}$ & 21 & 30.0 & $3.85-5.90$ & - \\
\hline
\end{tabular}

Data exıracted from Enginecred Material Handboxk: Ciramics and Glasses ( $\mid 9011)$, or kindly provided by Sumitomo Electric Industries, Lid.

\subsubsection{Rebolos}

O rebolo é, basicamente, constituído de um aglomerado de partículas duras (abrasivas), unidas por um ligante, sua eficiência está diretamente relacionada com o tipo do abrasivo empregado, o ligante e a porosidade existente. O grão abrasivo é responsável pelo corte da peça que está sendo retificada e o ligante tem como função manter o grão abrasivo no lugar. A porosidade tem a importante finalidade de armazenar temporariamente os fragmentos de usinagem.

Durante operação de retífica, ocorre desgaste da aresta cortante dos grãos, havendo forte perda de eficiência de corte e aumento das forças de corte. Para recuperar as arestas cortantes dos grãos, o mesmo deve ser dressado a seco, e removida a liga vítrea frágil.

As ferramentas de corte para a retificação possuem uma parte ativa e uma parte inativa que serve de suporte ao abrasivo. Os abrasivos podem fixados uns aos outros por meio de uma liga metálica, resinóide ou vitrificada. As ligas metálicas são menos sensíveis a irregularidades. As ligas resinóides apresentam maior desgaste que as ligas metálicas, mas seu poder de corte é muito maior. São indicadas para a usinagem de materiais frágeis, como 
as cerâmicas. As ligas vitrificadas apresentam características, em relação ao desgaste e poder de corte, intermediárias entre as metálicas e as resinóides. As ligas têm tanto a função de reter o abrasivo firmemente durante a usinagem como de destacá-los progressivamente (WREGE, 2000).

Os tipos mais comuns de ligantes são:

- $\quad \underline{V}$ - VITRIFICADOS

São os mais comuns, muito utilizados em retífica de precisão, tendo baixa sensibilidade à altas temperaturas, devido à sua estrutura porosa.

- $\mathrm{M}$ - METAL

São os mais utilizados com SUPERABRASIVOS (CBN e DIAMANTE)

- $\quad$ B-RESINÓIDES

De baixa porosidade, dão excelente acabamento superficial, sendo indicados para operações de acabamento. Tem elevada sensibilidade à altas temperaturas, exigindo refrigeração intensa e constante.

A preparação do rebolo antes do processo de retífica inclui o processo de ajuste e de dressagem. $O$ ajuste refere-se à remoção de material para realinhar a concentricidade do rebolo. Também por esse processo, pode-se criar um formato desejado no rebolo. A dressagem refere-se ao processo de criação de uma topografia específica na superfície ativa do rebolo, para obter um desejado comportamento de retífica. (utiliza-se uma ponta de diamante para realizar a dressagem).

A seleção do rebolo, conforme afirma SUBRAMANIAN et al (1990), inclui o tipo, tamanho distribuição do tamanho e concentração de A seleção da liga inclui a dureza, rigidez, porosidade e condutividade térmica.

A flexibilidade local do rebolo tem um efeito importante quando se considera uma região do processo de retificação. Ele cita a otimização do processo através da adoção de ligas flexíveis para reter os grãos abrasivos, pois assim o material cerâmico é protegido contra sobrecargas através da estabilização dos componentes da força normal de corte. Este requisito é encontrado nos rebolos diamantados com ligantes resinoides (LAMMER (1990)).

$\mathrm{Na}$ escolha da ferramenta abrasiva, diversos parâmetros de usinagem são analisados. Para que haja remoção de material é necessária que uma pressão mínima de usinagem deve ser excedida. Quanto menor o tamanho do grão abrasivo maior será a pressão a ser exercida. A influência do tamanho do grão e da pressão de contato pode ser explicada considerando as condições prevalecentes em cada partícula abrasiva individualmente (SPUR \& WEIGMANN (1996)). A força normal exercida na cerâmica pelo rebolo, como resultado de uma determinada pressão de contato, é distribuída individualmente entre as partículas de penetrantes na cerâmica. O número de partículas em 
contato com a cerâmica á determinado pelo tamanho do grão Figura 22. Assumindo que todas as partículas abrasivas na superfície da ferramenta penetram na cerâmica, quando o tamanho do abrasivo á alterado, o número de partículas cortante na cerâmica muda na proporção inversa do quadrado da diferença dos tamanhos de grão (REGIANE, 1997).

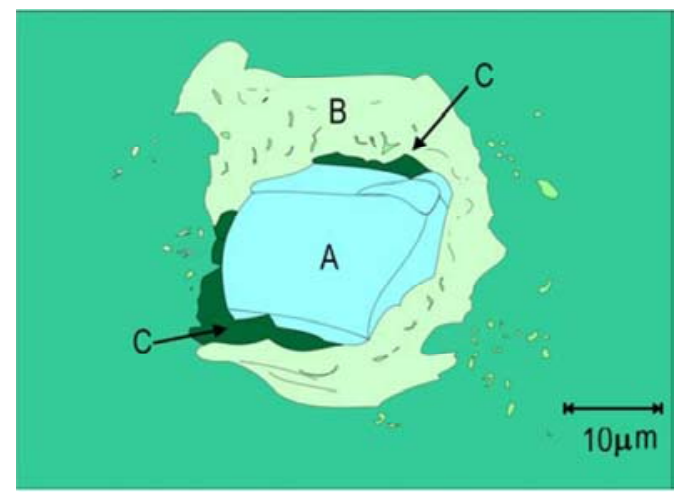

Figura 22 - Desenho esquematico de um grão abrasivo em um filme flexivel. Em (A) grão, (B) Resina deformada, (C) vazio devido aos deslocamentos do grão (HIGUCHI et al, 1994) apud (REGIANE, 2000).

O tamanho do grão abrasivo é medido em mesh/polegada, variando de 8 (grosseira) até 1200 mesh (ultrafina), em pesquisas comercialmente encontra-se valores na escala de 100.000 mesh, são os nano-abrasivos. As classes mais grosseiras são utilizadas para taxas de remoção de material mais elevadas, na retífica de peças de grande porte, materiais moles, e quando a superfície de contato entre o rebolo e a peça é grande. As granulações mais finas são utilizadas quando se deseja elevada qualidade de acabamento superficial, materiais duros e pequena área de contato.

A alta dureza dos materiais cerâmicos torna extremamente restrita a utilização de abrasivos para a realização dos processos de usinagem. Na escala Mohs a alumina e o carboneto de silício apresentam dureza 9 e os carbonetos de tungstênio e vanádio dureza 9,5. Desde que sejam mais duras que o componente a ser usinado, poderá ser utilizado o diamante, o nitreto de boro cúbico, alumina, carbeto de silicio, zirconia entre outros. Uma das mais importantes características dos abrasivos é a clivagem. Esta pode ser definida como sendo a capacidade de rompimento do cristal ao longo de um plano cristalográfico particular (WREGE, 2000).

\subsubsection{Fixação da peça}

A peça a ser usinada deve estar rigidamente fixada no equipamento de usinagem, numa mesa ou num eixo árvore. Como neste estado a resistência mecânica é muito baixa, a rigidez muito alta e a fragilidade também alta, pontos de contato podem causar enorme concentração de tensões e fraturar o corpo ou a superfície. Quando a fixação for feita por grampos ou braçadeiras deve-se projetá-los para que a área de contato seja maximizada 
para reduzir as tensões de contato. Peças furadas são normalmente suportadas por um mandril rotativo. Pinças e fixação a vácuo também são utilizadas (GAMBALE, 2010).

\subsubsection{Velocidade de Usinagem}

Velocidade máxima de usinagem deve ser produzir uma superfície aceitável sem trincas, na obtenção de velocidade de usinagem um compromisso deve ser estabelecido entre: velocidade relativa do Blank, velocidade da ferramenta de corte, profundidade de corte e área de contato. Ferramentas perfiladas para operações de usinagem por mergulho apresentam elevada área de contato que podem ser compensadas por baixa velocidade de mergulho (FORTULAN, 1997).

\subsubsection{Parâmetros de Usinagem}

São apresentados resultados de torneamentos realizados em cerâmicas no estado verde, relacionando os parâmetros de usinagem com a qualidade superficial para diferentes materiais e, também, com a força de corte para a alumina.

Maier e Michaeli (1997) encontraram em seus experimentos (Figura 23) que a velocidade de corte bem como a profundidade de corte tem uma pequena ou nenhuma influência na qualidade superficial. Uma diminuição no avanço leva a uma melhor qualidade superficial a qual é finalmente limitada pelo tamanho do grão do composto cerâmico. Portanto, para um processo de corte econômico com uma qualidade superficial suficiente, a capacidade de corte pode ser aumentada através da profundidade de corte e velocidade de corte. Entretanto deve ser notado que o aumento na profundidade de corte leva a um aumento das forças de corte, a qual induz momentos de flexão na peça e o aumento da velocidade de corte gera aumento das forças centrífugas, então ambas as variações são limitadas pela resistência a verde da peça.
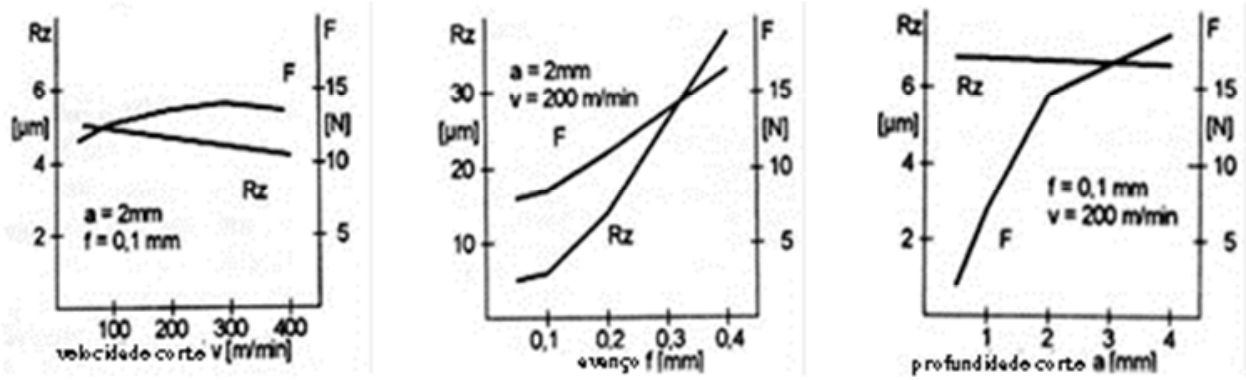

Figura 23 - Rugosidade Rz e força de corte resultante F em relação a: (a) Velocidade de corte, (b) Avanço e (c) Profundidade de corte (MAIER; MICHAELI, 1997).

Klocke, Gerent e Shippers (1999) realizaram experimentos para determinar quais condições de usinagem eram mais adequadas para operações de torneamento. O método utilizado envolve o torneamento de um cone ao invés de um cilindro de material a ser 
usinado no torno. A vantagem dessa abordagem é que a profundidade de corte aumenta continuamente durante toda a operação de corte.

\subsubsection{Usinagem pós sinterização}

As cerâmicas são extremamente frágeis e um defeito critico gerado na superfície de um componente, causado por usinagem imprópria, pode acarretar uma quebra catastrófica da peça, especialmente se condições de carregamento desfavorável ocorrer durante o seu funcionamento. Outra importancia associada a usinagem é relativa a remoção do defeito superficial adquirida na conformação e sinterização.

Devido à cerâmica ser deficiente relativamente ao seu comportamento dinâmico, há uma necessidade de acabamento superficial alto. Estas necessidades são verificadas quando as superfícies são submetidas o desgaste por atrito de deslizamento. Como exemplo, é possível citar os mancais de carboneto de silício ( $\mathrm{SiC}$ ) para bombas de líquidos corrosivos ou abrasivos que requerem acabamento superficial de 0,08 um de rugosidade e 0,3 H.m de planicidade. Zircônia $\left(\mathrm{ZrO}_{2}\right)$ e nitreto de silício ( $\mathrm{SiN}$ ) são usados em insertos e juntas de braços mecânicos e requerem rugosidade inferior a $23 \mu \mathrm{m}$.

Apesar das vantagens advindas de tais aplicações, atualmente há um número limitado de técnicas de usinagem possíveis de serem aplicadas ao acabamento ou super acabamento de cerâmicas avançadas. Estas técnicas incluem as de corte abrasivo com aresta de corte indefinida geometricamente como a retificação, brunimento, lapidação e polimento (KÓNIG \& POPP, 1989). 


\section{MATERIAIS E MÉTODOS}

Neste trabalho, buscou-se por uma faixa otimizada de valores de torque para estabelecer os parâmetros de controle da usinagem onde o avanço pode ser controlado de acordo com a agressividade da usinagem dentro dos limites estabelecidos, obtendo as propriedades mecânicas desejadas.

Para garantir a qualidade da retificação, a rotação do rebolo e a do corpo de prova deve permanecer as mesmas durante todo o processo, ambas conectadas a um computador que controla o avanço da ferramenta para não exceder o torque máximo estipulado e a rotação mínima desejada. Um planejamento experimental foi elaborado para aquisição de dados de usinagem, conforme mostrado no organograma da Figura 24.

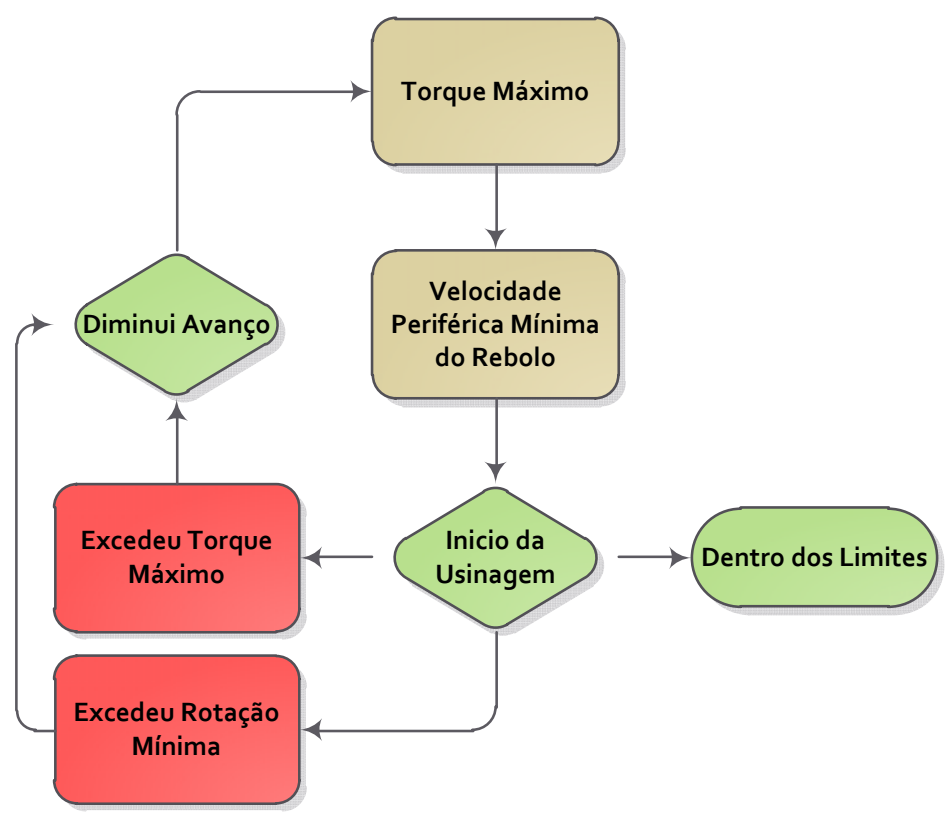

Figura 24 - Controle da Usinagem (Fonte: Autor)

Para isso foi projetado um banco de aquisição de dados experimentais para medir o torque máximo suportado pelo corpo de prova sem introdução de danos estruturais críticos na peça obra e para definir a faixa de rotação ideal para não gerar imperfeições na peça

No projeto do banco de esforços foi incluído o projeto de um torquímetro para o eixo árvore do porta peça, para medição em tempo real do torque consumido na usinagem.

Corpos de prova em alumina foram prensados isostáticamente, usinados a verde no formato cilíndrico e sinterizados. Os cilindros $(\varnothing 7 \times 50 \mathrm{~mm})$ serão rompidos por ensaio de flexão a 4 pontos (ASTM C1684-08) e na região de fratura será analisada a superfície de fratura por microscopia ótica e por microscopia eletrônica de varredura. Foi correlacionada a agressividade de corte com as propriedades mecânicas e introdução de defeitos.

Como estudo de caso, foi aplicada a usinagem a verde na usinagem de pinos de implantes dentários. 


\subsection{Projeto do banco de ensaios de usinagem}

A maioria das etapas do modelo proposto possui interações, iterações e retroalimentação, conforme ilustra a Figura 25.

Em quase todo o projeto, foi adotado um procedimento de tomada de decisão, baseado nas propostas de Pahl (2005) e Baxter (1998), ou seja, dado o elemento motivador, foi feito um levantamento das opções e a seleção da melhor solução em vista dos recursos, demanda ou algum outro fator de relevância.

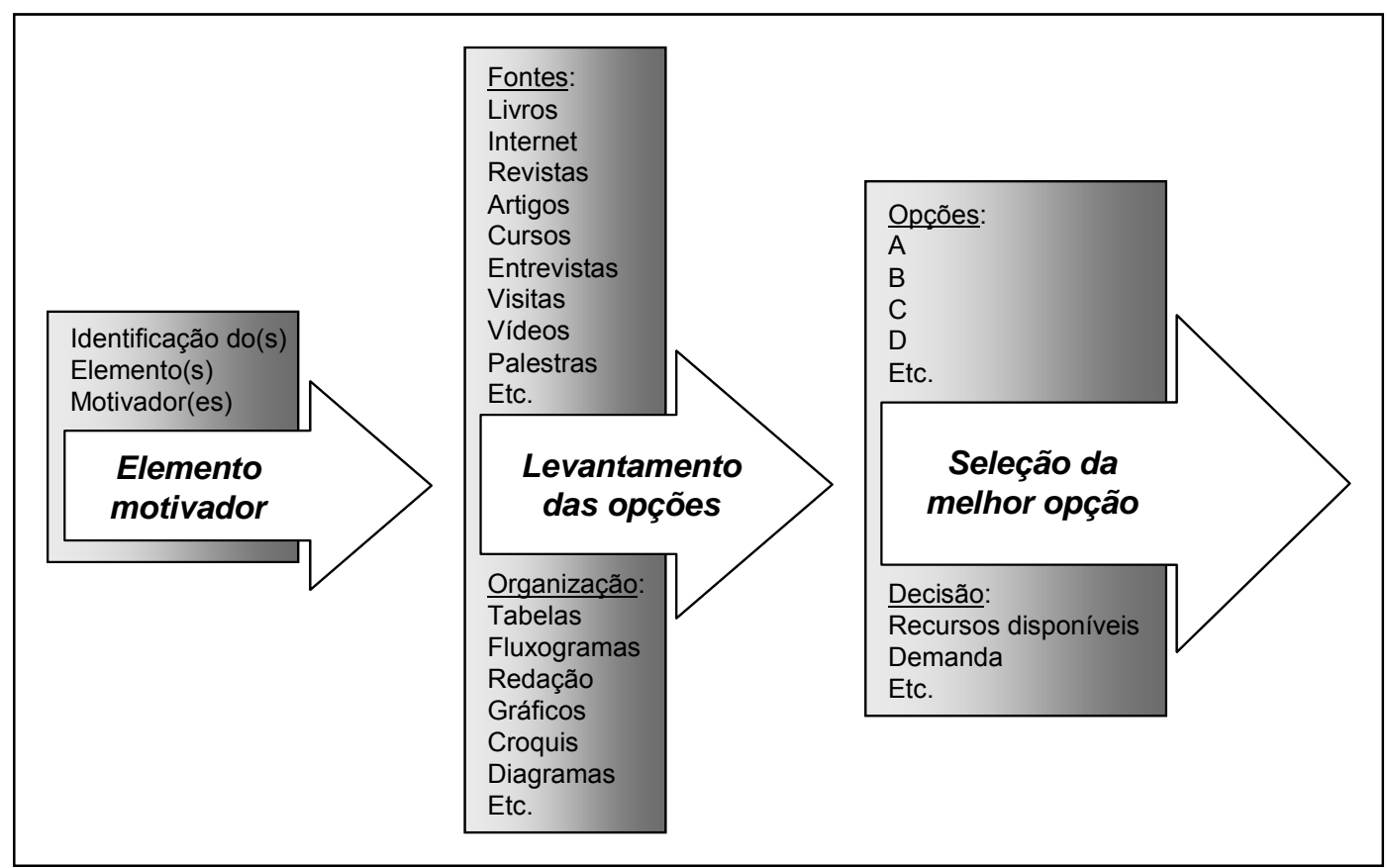

Figura 25 - Procedimento de tomada de decisão resumido (Pahl 2005).

\subsubsection{Identificação da demanda}

É interessante para o País gerar riquezas, não apenas agrícola ou petrolífera, mas também industrial e tecnológica. Situações em que os produtos se encontram em elevado estágio de desenvolvimento, como o caso de componentes eletrônicos, há a necessidade de absorver o desenvolvimento dos países de vanguarda adaptando ao Brasil novas tecnologias e acelerando o desenvolvimento. Investir, não apenas em novas tecnologias, mas trazê-las de fora, faz-se necessário. A tecnologia eletrônica tem expressivo crescimento mundial e é totalmente desinteressante abrir mãos dos frutos que essa tecnologia pode trazer ao País.

O País desenvolveu capacidade nas áreas de usinagem convencional e também em áreas específicas, como, a retificação e o corte de placas cerâmicas para pisos e 
revestimentos, porém, praticamente não há publicações sobre o processo de usinagem a verde de cerâmicas.

\subsubsection{Conclusão da análise de viabilidade}

Verificou-se que esse projeto é viável. Os ganhos à tecnologia brasileira serão substanciais visto que esse projeto agrega temas como metodologias de projeto, máquinas de precisão, corte de materiais frágeis e conceitos de usinagem a verde. Moldado o projeto e fabricação do protótipo mostram-se viáveis em vista da tecnologia e recursos disponíveis.

\subsubsection{Projeto adaptativo em banco anterior de Gambale (2008)}

Para identificar e delimitar as forças de corte que influenciam na qualidade estrutural da peça a ser usinada, um projeto adaptativo no equipamento anterior foram necessárias, assim, reduzindo fatores físicos indesejáveis como vibração e momento de inercia devido a alta rotação do rebolo, e acoplamento de sensores permitindo o monitoramento de todo o processo de usinagem, sendo necessário:

- Minimizar o ruído produzido pelo cabeçote;

- Introdução de indicadores de rotação e torque;

- Fixar o Spindle com o eixo e o rebolo e adaptar um motor de baixa rotação juntamente com o corpo de prova na mesa móvel, minimizando o efeito giroscópio causado pela grande rotação.

O momento de inercia gerado pelo conjunto eixo, induzido e rebolo a elevadas rotações é explicado pelo efeito giroscópio: consiste essencialmente em uma roda livre para girar dentro de uma gaiola circular e com uma propriedade: opõe-se a qualquer tentativa de mudar sua direção original. A equação fundamental que descreve o comportamento do giroscópio é:

$$
\tau=\frac{d L}{d T}=\frac{d(I \omega)}{d t}=I a
$$

onde $\tau$ e $\mathrm{L}$ são, respectivamente, o torque sobre o giroscópio e seu momento angular. O escalar I é seu momento de inércia, o vetor $\omega$ é sua velocidade angular e o vetor a é sua aceleração angular. Quando um torque t é aplicado perpendicularmente ao eixo de rotação, consequentemente perpendicular a L, resulta-se em um movimento perpendicular a ambos t e L. Este movimento é chamado de precessão. A velocidade angular de precessão $\Omega$ P é dada por:

$$
\tau=\Omega \mathrm{PxL}
$$

A precessão pode ser demonstrada colocando um giroscópio que está em rotação com seu eixo, horizontalmente e levemente preso por uma das extremidades. Ao invés de cair, como esperado, o giroscópio parece desafiar a gravidade mantendo seu eixo na 
horizontal, mesmo que uma de suas extremidades não esteja presa. Esta extremidade descreve um movimento circular no plano horizontal. $O$ torque no giroscópio é sustentado por duas forças: a gravidade agindo para baixo no centro de massa do dispositivo e uma força normal, de mesmo módulo, agindo para cima no ponto de apoio de uma das extremidades (UNICAMP, 2011).

Neste banco, se o Spindle fosse montado sobre a mesa $X Y$, o mesmo efeito giroscópico seria observado, então decidiu-se pela inversão do projeto que é comum para retificas comerciais, com o cabeçote fixo e a peça obra móvel.

\subsection{Formulação Cerâmica}

A mistura/desaglomeração da alumina foi realizada em moinho de jarros elementos de moagem de cilindros de zircônia ( $\varnothing 12 \mathrm{~mm}$, h 12mm). Uma suspensão com 30 vol\% de pó foi elaborada com volume líquido composto por 68 vol\% de água destilada e deionizada, 1 vol\% de PVAl e 1 vol\% de poliacrilato de amônia (Dispersal 130. O granulado do pó foi obtido pela secagem em spray drier.

Alumina Calcinada A1000-SG, (Almatis, Inc.) com diâmetro médio equivalente de partícula de $0,40 \mu \mathrm{m}$, área superficial de $7,70 \mathrm{~m}^{2} / \mathrm{g}$, $\rho_{\text {real: }}: 3,99 \mathrm{~g} / \mathrm{cm}^{3}$ Tabela 3 .

Tabela 3 - concentração de diversos materiais contidos na alumina.

\begin{tabular}{|l|l|l|l|l|}
\hline $\mathrm{Fe}_{2} \mathrm{O}_{3} \%$ & $\mathrm{Na}_{2} \mathrm{O} \%$ & $\mathrm{CaO} \%$ & $\mathrm{~B}_{2} \mathrm{O}_{3} \%$ & $\mathrm{MgO} \%$ \\
\hline 0,02 & 0,07 & 0,02 & 0,001 & 0,04 \\
\hline
\end{tabular}

\subsubsection{Corpos de prova}

Através da prensagem isostática obtém-se um tarugo em bruto com dimensões superiores às do corpo de prova à verde. Em seguida, a forma final do corpo de prova é obtida por usinagem ainda a verde (não queimada). As dimensões a verde devem ser ainda superiores às do corpo de prova para compensar a retração de sinterização (Figuras 27 a 30 ). Foi considerada uma retração de $23 \%$ para a etapa de prensagem e de $16 \%$ para a de sinterização, adicionada de uma sobre-espessura para usinagem de $2 \mathrm{~mm}$ no diâmetro (FORTULAN, 2007). 


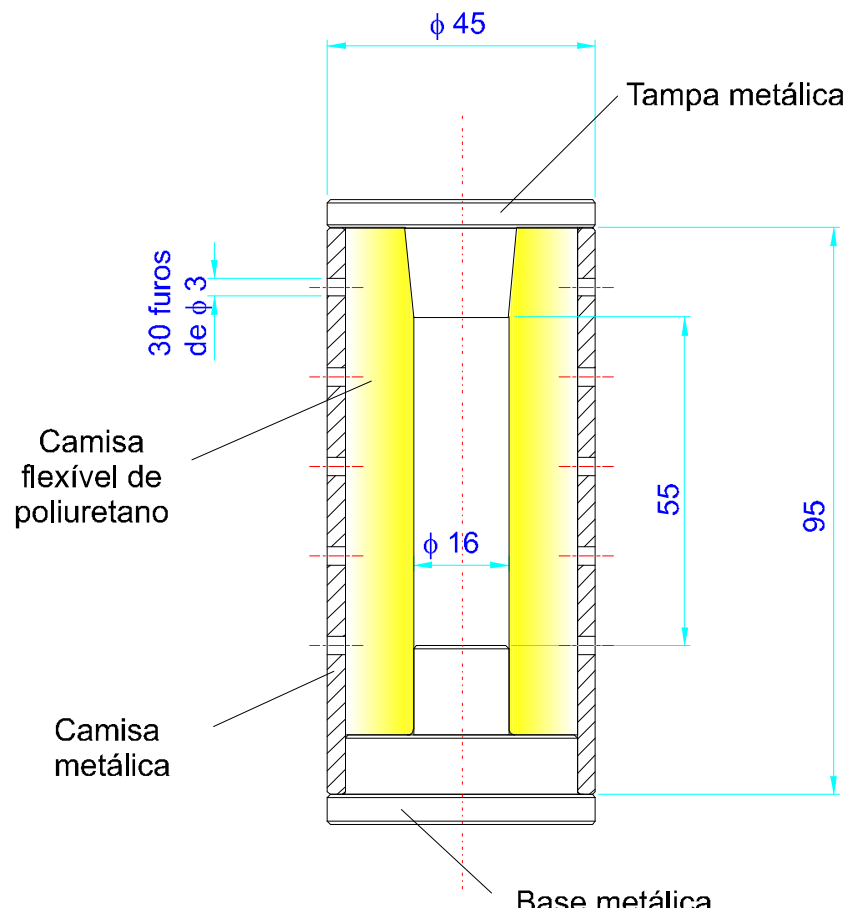

Figura 26 - Desenho esquemático do molde para prensagem isostática (dimensões em mm) (FORTULAN, 2007).

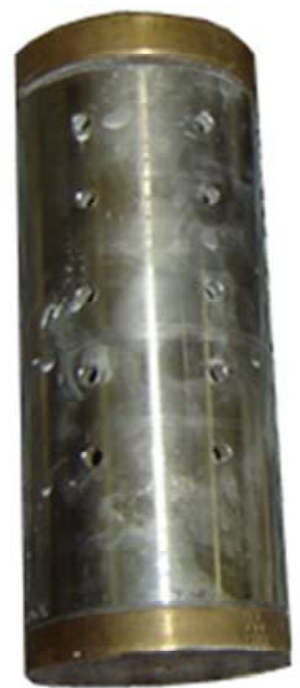

A

Figura 27 - (A) vista do molde, (B) vista superior do molde para prensagem isostática e (C) tarugo resultante do molde (FORTULAN, 2007).

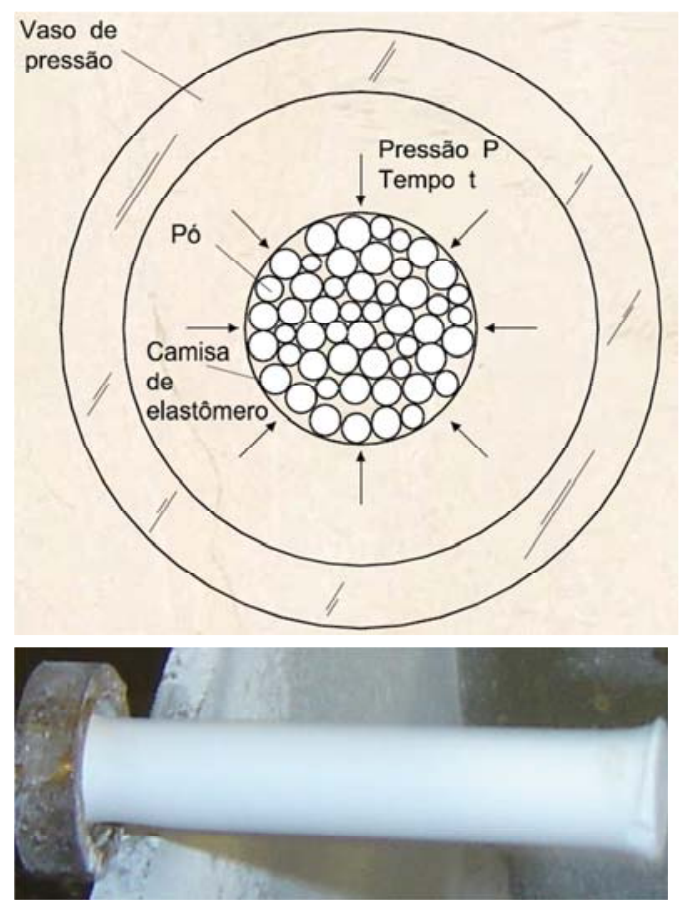

B C 


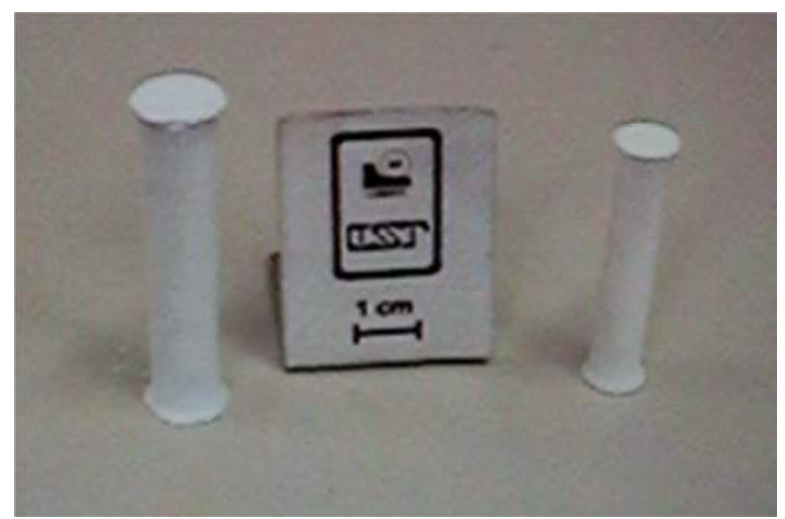

Figura 28 - Tarugos prensados para obtenção dos corpos de prova a verde (à esquerda) e sinterizado (à direita)

Foram planejadas amostras prensadas com 100 e $200 \mathrm{MPa}$ por $30 \mathrm{~s}$, originalmente com comprimento de $55 \mathrm{~mm}$ e diâmetro $10 \mathrm{~mm}$, após usinagem a verde diâmetro $07 \mathrm{e}$ comprimento de 50mm Figura 29.

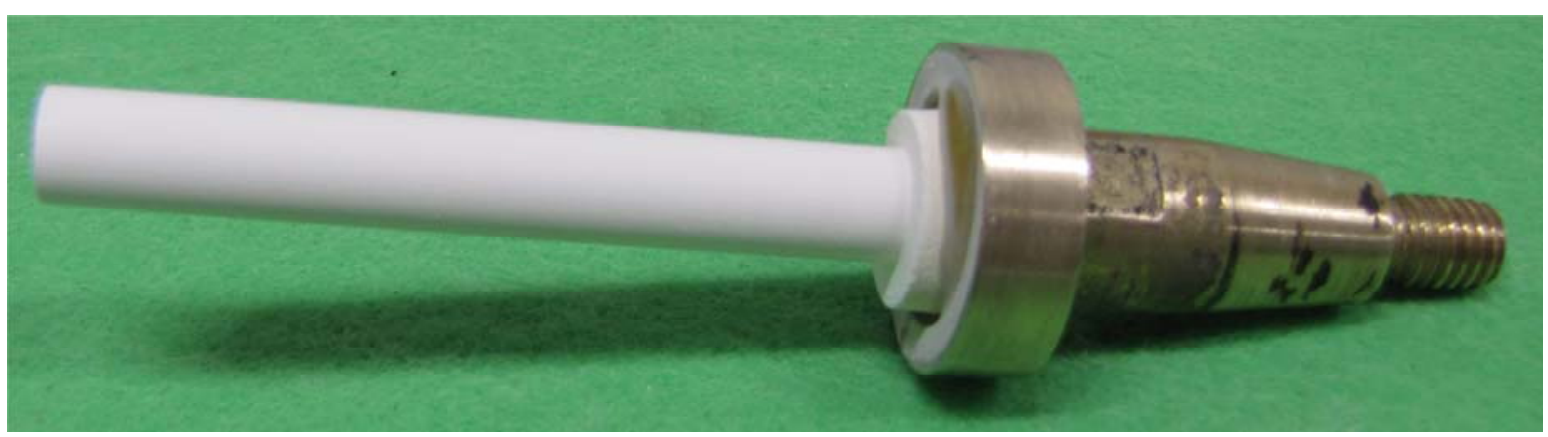

Figura 29 - Tarugo usinado com dimensões $\varnothing 7 X 50 \mathrm{~mm}$.

Após sinterização, as amostras contraem aproximadamente 16\%, assim foram obtidos medidas próximas a diâmetros de $6 \mathrm{~mm}$ e comprimento de $40 \mathrm{~mm}$.

Ensaios de flexão foram efetuados com amostras a verde e sinterizadas, os ensaios de compressão apenas em amostras a verde.

\subsubsection{Sinterização}

Após secagem em estufa durante 12 horas à $100^{\circ} \mathrm{C}$, as peças foram sinterizadas em forno elétrico tipo câmera à $1600^{\circ} \mathrm{C}$ com patamar de $2 \mathrm{~h}$.

\subsection{Ensaios}

Para avaliar os danos estruturais causados pela usinagem a verde, em diferentes condições de avanço e profundidade, e a duas diferentes pressões de conformação o comportamento tensão-deformação das cerâmicas frágeis é avaliado na maioria das vezes 
por um ensaio de flexão transversal, onde um corpo-de-prova na forma de uma barra, com seção reta circular ou retangular, é flexionado até sua fratura, utilizando uma técnica de carregamento em três ou em quatro pontos. No ponto de carregamento, a superfície superior do corpo-de-prova é colocada em um estado de compressão, enquanto a superfície inferior encontra-se em tração. A tensão é calculada a partir da espessura do corpo-deprova, do momento fletor, e do momento de inércia da seção reta. A tensão de tração máxima existe na superfície inferior do corpo-de-prova, diretamente abaixo do ponto de aplicação da carga (CALLISTER, 2005).

A tensão no momento da fratura quando se emprega esse ensaio de flexão é conhecida por resistência à flexão, módulo de ruptura, resistência à fratura, e consiste em um importante parâmetro mecânico para os materiais cerâmicos frágeis (CALLISTER, 2005).

Uma vez que, durante a flexão, um corpo de prova está sujeito tanto a tensões compressivas como a tensões de tração, a magnitude da sua resistência à flexão é maior do que sua resistência à fratura por tração. Ademais a tensão $\sigma$ dependerá do tamanho corpo de prova. Com o aumento do volume do corpo-de-prova (sob tensão) existe um aumento na probabilidade de existência de um defeito causador de trincas e, consequentemente, uma diminuição na resistência à flexão (CALLISTER, 2005).

Os ensaios se basearam na norma ASTM C-1684-08 (2008). O teste foi realizado na máquina EMIC à uma taxa de $0,2 \mathrm{~mm} / \mathrm{min}$ com as peças apoiadas na configuração apresentada a seguir (Figura 30), onde 1- amostra, 2- suporte dos rolos superiores, 3suporte dos rolos inferiores, 4- rolo central de apoio e 5- rolos de carregamento.
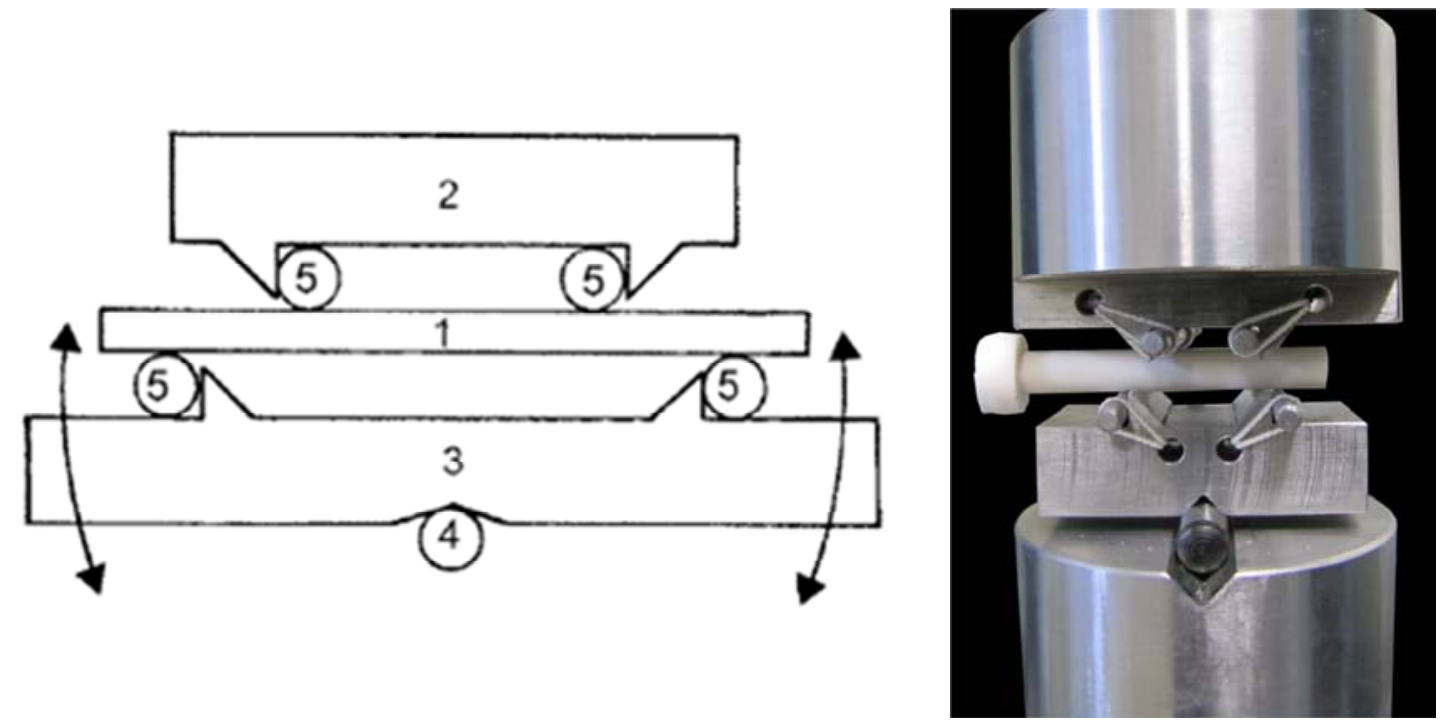

Figura 30 - Esquema do teste de flexão a 4 pontos.

O ensaio de flexão a 4 pontos é regida pela equação (8) 


$$
\sigma=\frac{4 P L_{0}}{\pi D^{3}}
$$

Onde $D$ é o diâmetro do tarugo em $\mathrm{mm}, \mathrm{L}_{0}$ é a largura do span em $\mathrm{mm}, \mathrm{P}$ é a força de quebra em $\mathrm{N}$ e $\sigma$ é a força em MPa.

\subsubsection{Análises Experimentais de Usinagem}

Os corpos de prova cilíndricos foram analisados quanto às propriedades mecânicas de flexão, as quais foram confrontadas quanto à influência das variáveis de usinagem tais como: avanço longitudinal, profundidade de corte e taxa de remoção de material. A tabela 4 a seguir apresenta as condições de usinagem aplicadas.

Tabela 4 - Condições de usinagem.

\begin{tabular}{|c|c|c|c|}
\hline Grupo & Teste & $\begin{array}{l}\text { Avanço } \\
\text { (mm/min) }\end{array}$ & $\begin{array}{l}\text { Profundidade de corte } \\
(\mathrm{mm})\end{array}$ \\
\hline \multirow{4}{*}{ 1-100MPa } & 05F100 & 100 & \multirow{4}{*}{0,5} \\
\hline & 05F200 & 200 & \\
\hline & 05F300 & 300 & \\
\hline & 05F400 & 400 & \\
\hline \multirow{4}{*}{ 2-100MPa } & 1F100 & 100 & \multirow{4}{*}{1} \\
\hline & 1F200 & 200 & \\
\hline & 1F300 & 300 & \\
\hline & $1 \mathrm{~F} 400$ & 400 & \\
\hline \multirow{4}{*}{ 3-200MPa } & 1F100 & 100 & \multirow{4}{*}{1} \\
\hline & 1F200 & 200 & \\
\hline & $1 F 300$ & 300 & \\
\hline & $1 \mathrm{~F} 400$ & 400 & \\
\hline
\end{tabular}

Para avaliar os danos estruturais causados pela usinagem a verde, em diferentes condições de avanço e profundidade, utilizou-se da flexão a 4 pontos (ASTM C1684-08) Figura 32 e na região de fratura foi analisada a superfície fraturada por MEV. Amostras para ensaio de resistência à compressão dos corpos a verde também foram realizados (ASTM C1424 - 04) para correlação com a tolerância ao torque de usinagem.

Para cada teste, foram utilizadas 5 amostras cilíndricas sinterizadas, totalizando sessenta, analisadas para determinar a resistência à ruptura por flexão a 4 pontos (ASTM C1684-08) utilizando a Máquina Universal de Ensaios da EMIC Figura 31, com velocidade do travessão em $0,2 \mathrm{~mm} / \mathrm{min}$ com célula de carga de $20 \mathrm{kN}$. 


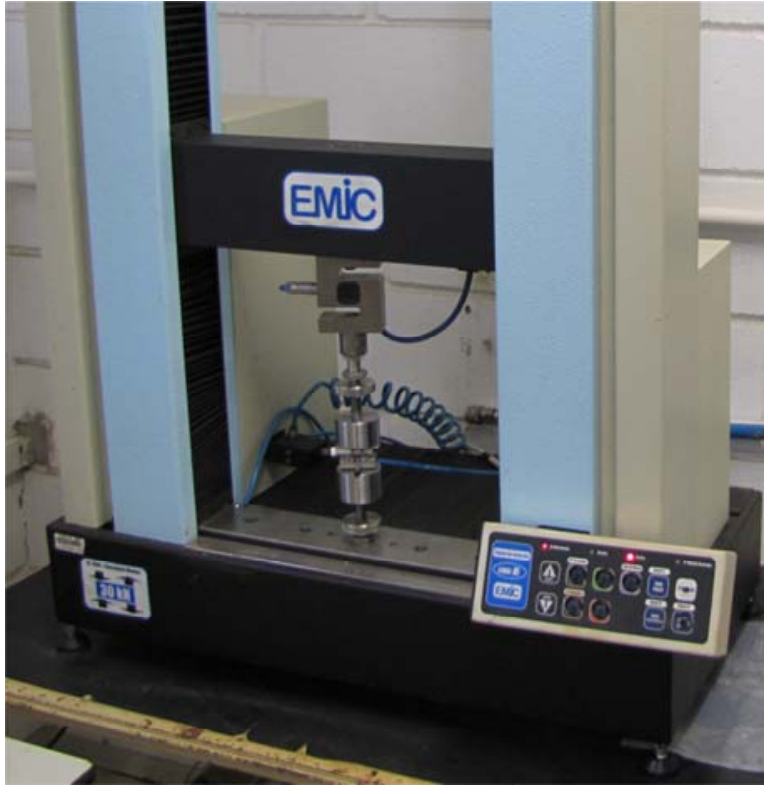

A

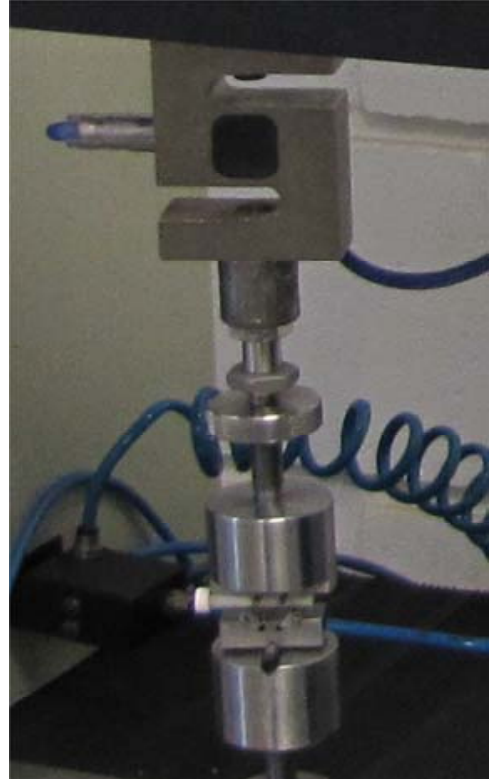

B

Figura 31 - Em (A) Máquina Universal de Ensaios da EMIC e (B) Célula de carga de 20kN

O experimento de usinagem visa verificar as condições limite de usinagem através da análise dos seguintes parâmetros: avanço do rebolo, taxa de remoção de material e profundidade de corte.

Em todos os experimentos trabalhou-se com velocidade periférica do rebolo em $45 \mathrm{~m} / \mathrm{s}$, a Tabela 4 apresenta as condições de usinagem aplicadas e a Figura 32 uma imagem instantânea da operação de usinagem.
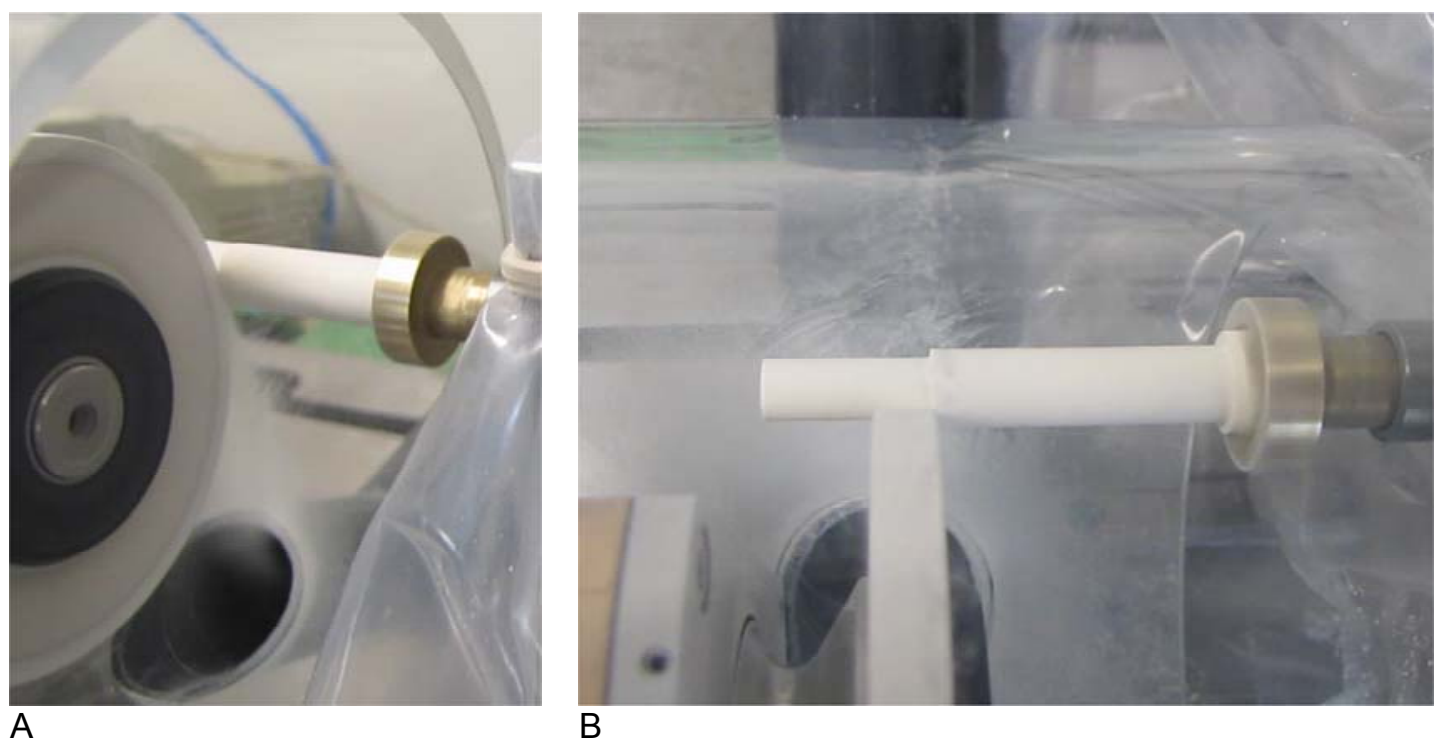

Figura 32 - Imagem da operação de usinagem, em (A) vista lateral e em (B) vista superior.

A taxa de remoção de material Q pode ser calculada de acordo com a Equação 9.

$Q=\pi \cdot d_{w} \cdot a_{e} \cdot V_{f}$ 
onde $d_{w}$ é o diâmetro da amostra, $a_{e}$ profundidade de corte e avanço $V_{f}$.

O nível da força de corte pode gerar defeitos críticos na superfície que acarretam na diminuição das propriedades mecânicas da amostra e em uma situação extrema a ruptura da amostra.

O rebolo foi dressado com velocidade periférica de $4 \mathrm{~m} / \mathrm{s}$ em suas superfícies radial e lateral. Para o primeiro grupo, a profundidade de corte foi fixada em $0,5 \mathrm{~mm}$ e no segundo $1 \mathrm{~mm}$, a taxa de alimentação variou entre 100 a $400 \mathrm{~mm} / \mathrm{min}$. As amostras no estado a verde foram obtidas com diâmetro final de 7,0 mm e comprimento de $50 \mathrm{~mm}$.

\subsubsection{Estudo de Caso - Implante Dentário}

A usinagem a verde foi aplicada no desenvolvimento de pinos dentários com núcleo denso e superfície porosa, com a utilização dos métodos de co-prensagem e usinagem em branco, para manufatura e acabamento final, respectivamente.

Pesquisas que visam manufatura de implantes ósseos têm desenvolvido métodos para aprimorar respostas mecânicas e biológicas ao implante. Inicialmente estruturas densas foram desenvolvidas, seguindo com as estruturas porosas, em conjunto com técnicas para recobrimentos de superfícies e, ultimamente, tecnologias para desenvolver materiais em gradiente funcional.

O desenvolvimento de peças heterogêneas confere aos materiais existentes características novas, as quais podem classificá-los como novos materiais. Em aplicações de substituição óssea estruturas heterogêneas são funcionalmente mais interessantes que as homogêneas, pois podem fornecer em uma mesma peça características de um material natural como osso, o qual apresenta em sua estrutura densidade diferente de poros.

Camilo (2010) conceituou um implante com núcleo denso e superfície com gradiente funcional de porosidade, impregnada de hidroxiapatita e biovidro para a ósseo integração.

Um material com estrutura totalmente densa, ao ser implantado em tecido ósseo pode não se fixar adequadamente ao tecido, pois a fixação do implante depende principalmente da interface do material. A porosidade controlada proporciona um ambiente propício para a fixação do implante. No entanto, um implante denso seria mecanicamente vantajoso, pois os vazios contidos em uma peça aumentam a propensão a fraturas.

O desafio em materiais com estrutura em porosidade gradual seria evitar a delaminação das interfaces com densidades diferentes, pois tem retração linear diferenciada no resfriamento após sinterização. Propostas de pesquisas com implantes em gradientes com região de transição, também conhecidos como Materiais em Gradiente Funcional (FGMs) com região de transição fornecem novas expectativas para reduzir ou eliminar problemas de fraturas, delaminação e soltura comuns em implantes homogêneos e/ou 
bifásicos. Neste sentido elaborou-se a metodologia de conformação e co-prensagem de vários dispositivos e seguido da usinagem White Machining.

Materiais utilizados nos componentes dos implantes, como componente estrutural bioinerte dos implantes foi utilizada a alumina calcinada A1000-SG, (Almatis, Inc.). Como agente formador de poros foi utilizado a sacarose (PA) da Synth (LABYNTH Prod. p/ laboratórios Ltda.). A sacarose foi separada em peneiras em dois intervalos de tamanhos de partículas $(177,0 \mu \mathrm{m}<$ tamanho $\mathrm{A}<300,0 \mu \mathrm{m}$ e $300,0 \mu \mathrm{m}<$ tamanho $<600,0 \mu \mathrm{m})$. Foram misturados $50,0 \%$ em volume (vol\%) do tamanho A e $50 \%$ vol\% do tamanho B. A porosidade planejada de $70,0 \%$ vol\%, requer uma entrada de $82,0 \%$ vol $\%$ de sacarose. Como ligante cerâmico foi empregado o polivinil-butiral (PVB) (Butvar B98). Como solvente do ligante e meio líquido da barbotina foi utilizado a acetona - ACS da (Labsynth Ltda.). Como solvente para lixiviação do açúcar foi usada água destilada nos corpos conformados. Foi utilizada a pré-queima a $900^{\circ} \mathrm{C}$ para remoção da sacarose o que conferiu para a usinagem o estatus de white machining.

A técnica de produção do Blank consistiu do processo de co-prensagem da barbotina seca com o pó de alumina, projetou-se o molde para dar forma de pino de dente nas peças. Com a metodologia de co-prensagem pode-se manufaturar peças com espessura da região porosa controlável. O controle da espessura foi realizado em função da quantidade de camadas de barbotina com formador de poros sobrepostas durante a secagem.

Na Figura 33 vê-se em (A) o desenho em 3D do molde projetado e em (B) o corpo de prova prensado resultante deste molde.
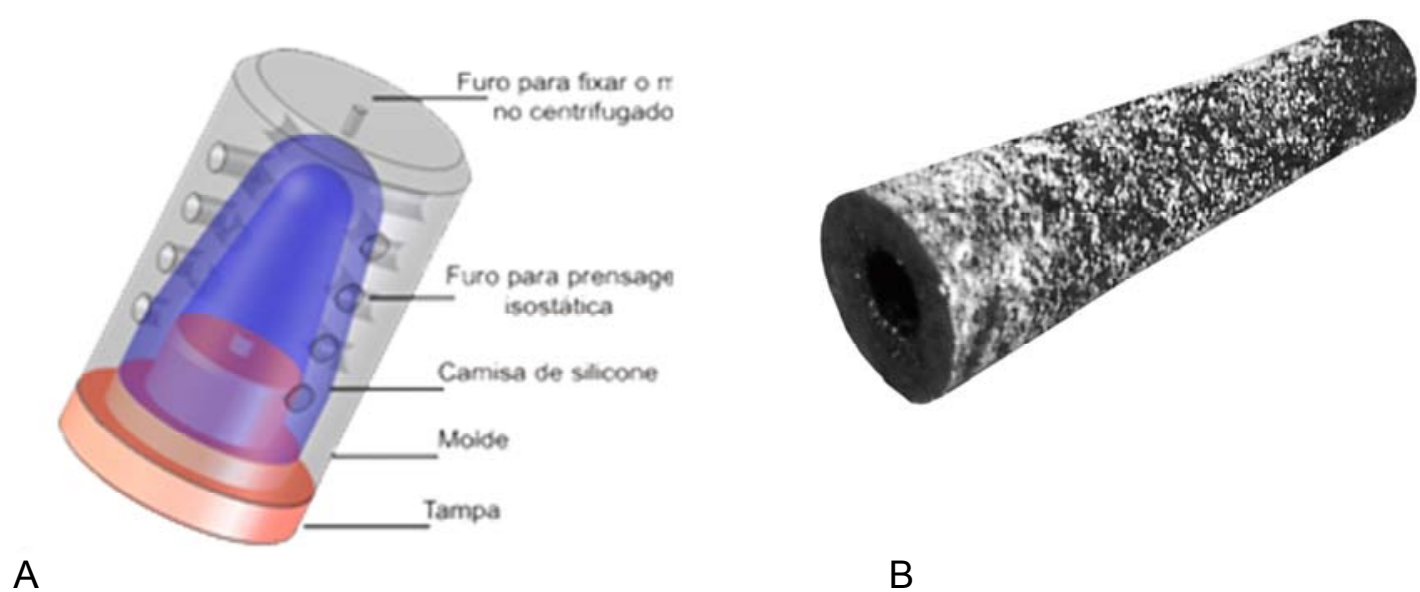

Figura 33 - Molde para prensagem isostática do corpo-de-prova. (A) llustração do molde; (B) Blank, resultante da co-prensagem (CAMILO, 2010).

Para não ocorrer aderência entre a peça prensada e o molde foi necessário lubrificação com grafite em pó na parede interna do molde de silicone o que é caracterizado pela cor escura externa ao Blank (Figura $33 \mathrm{~B}$ ). 
Para a usinagem em branco da peça, porosa externamente e com núcleo denso, foi necessário aumentar a espessura da região porosa na parte inferior do cone, devido a maior perda de material na parte inferior decorrente da usinagem. O Projeto da manufatura do Implante dentário em suas etapas de usinagem é mostrado na Figura 34.

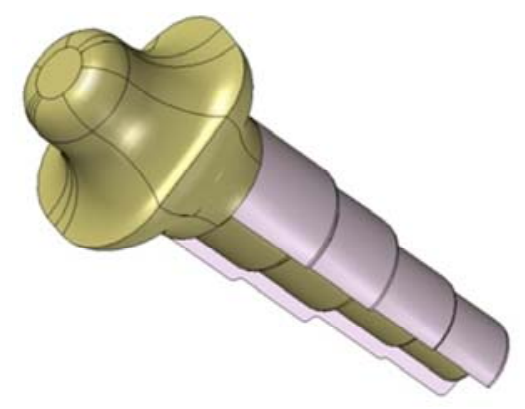

A

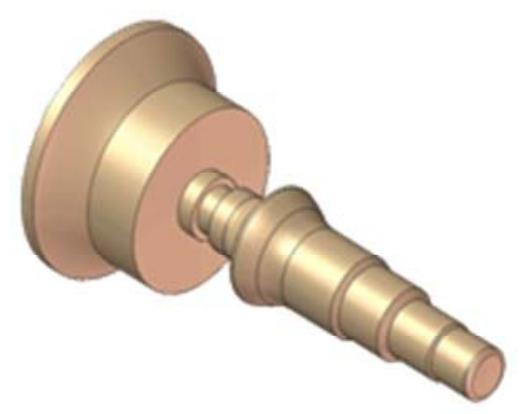

C

Figura 34 - Projeto da manufatura do Implante dental. (A) conceito em gradiente funcional e em corte (virtual) da camada porosa, (B) Blank pós prensagem, (C) usinagem a verde do Blank, (D) pino sinterizado (CAMILO, 2010).

O projeto do pino dentário foi realizado em CAD (Figura 35a), foram realizados pré testes de usinagem utilizando giz de lousa para conferir as dimensões do desenho, conforme ilustra a Figura 35. Os seguintes parâmetros de usinagem foram estabelecidos: rebolo de alumina eletrofundida marrom \#100 mesh, liga vítrea, com velocidade periférica de $54 \mathrm{~m} / \mathrm{s}$, velocidade de avanço em $0,55 \mathrm{~mm} / \mathrm{s}$ e profundidade de corte de $0,03 \mathrm{~mm}$ 

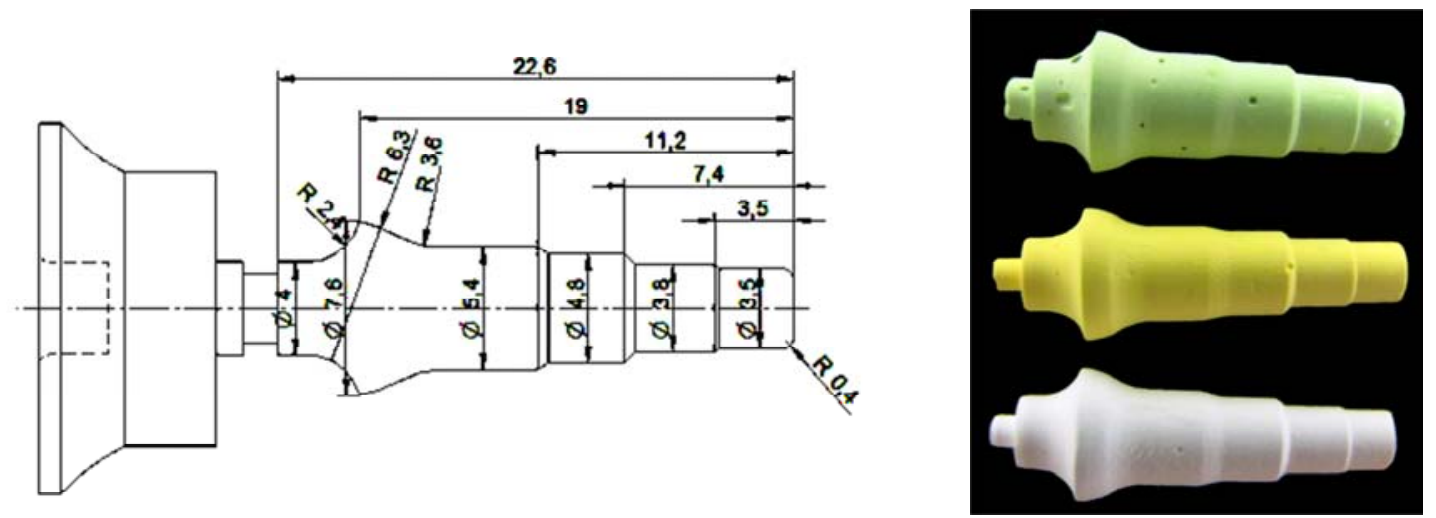

A

$\mathrm{B}$

Figura 35 - Dimensões do pino dentário, elaboradas em CAD (A), em (B) ensaios feitos em giz de lousa para conferir as dimensões. 


\section{RESULTADOS}

São apresentados os resultados, desde o preparo do pó cerâmico até a conformação dos Blanks, bem como o tratamento térmico, a usinagem nas diversas condições de processamento e as correlacionando com propriedades mecânicas, e, em estudo de caso, a aplicação de usinagem do implante dentário.

\subsection{Massa cerâmica}

Obtido pelo spray dryer, atenção é dada ao formato esférico dos grânulos conforme ilustra a Figura 36 (A),(B) e (C) aos vazios internos de cada grânulo e na Figura 36 (D), a vista superficial de um grânulo mostrando as partículas orgânicas agregadas.

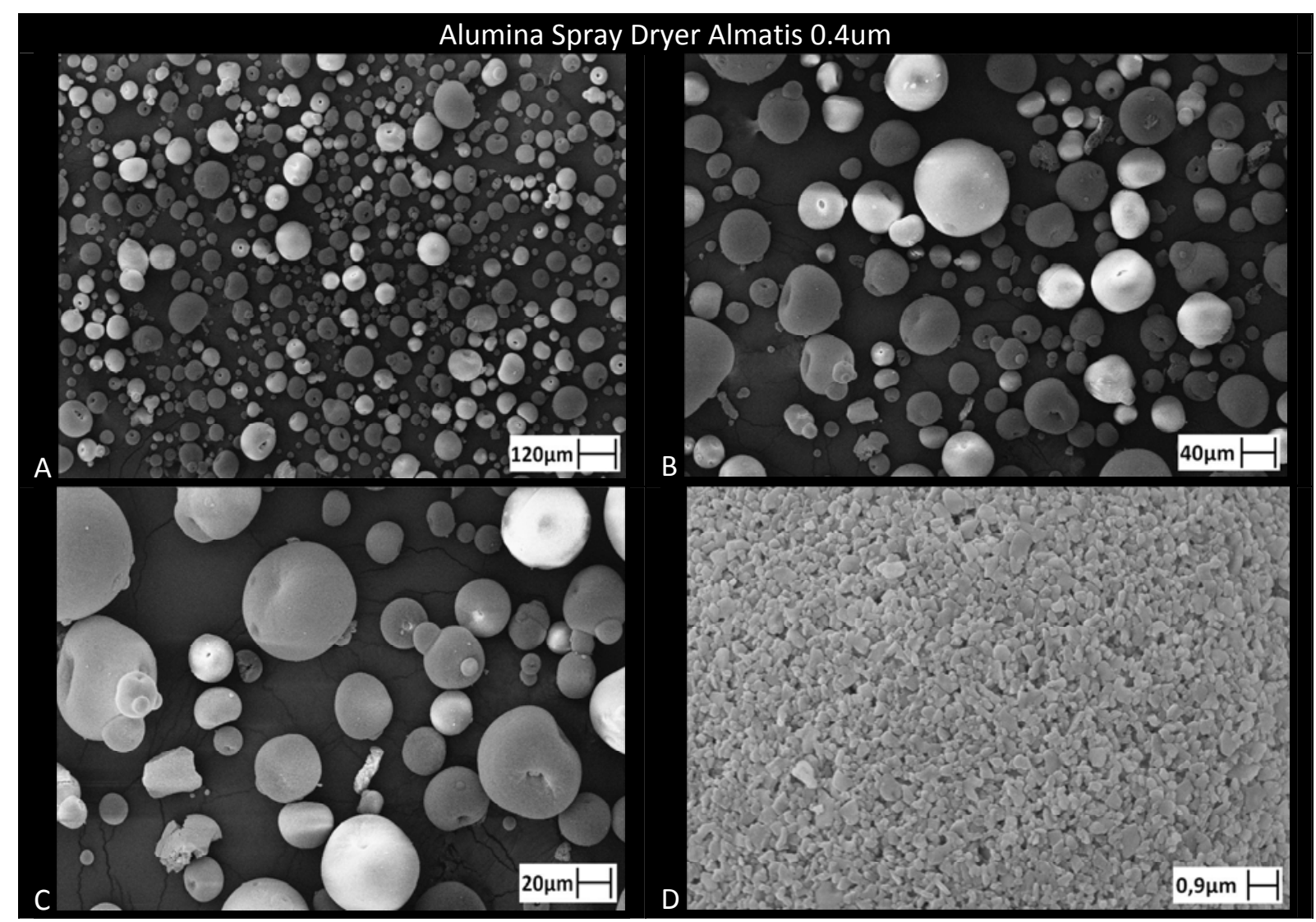

Figura 36 - Imagem em MEV realizada no pó de alumina e ligantes granulados em spray-drier em (A), (B) e (C) aglomerados esfericos e em (D) vista da superficie de um grânulo.

\subsection{Preparação das amostras}

Amostras foram prensadas isostaticamente entre 100 e $200 \mathrm{MPa}$ durante 30 s de patamar na pressão máxima utilizando o processo de "wet bag" em moldes cilíndricos. Tarugos foram gerados com diâmetro mínimo de $10 \mathrm{~mm}$ e comprimento de $55 \mathrm{~mm}$. Parte dos tarugos foram mantidos in natura com repouso mínimo de $48 \mathrm{~h}$ e os demais foram tratados em estufa esterilizadora a $100^{\circ} \mathrm{C}$ durante 24 horas, acima da temperatura de transição vítrea 
do PVAl (tg $\sim 85^{\circ} \mathrm{C}$ ). Buscou-se o alivio de tensão e eliminação de água absorvida no polímero para melhor compreender com isso, seu comportamento na usinagem, em seguida foram retificados no estado a verde. As Figuras 37 e 38 mostram a ampliação das amostras prensadas a 100 e $200 \mathrm{MPa}$. Na posição da base em contato com a parede metálica do molde, observa-se pelos contornos dos aglomerados deformados que a compressão mais severa (200MPa) diminuiu-se drasticamente os espaços vazios entre os grânulos de alumina, que é um indicativo do ganho obtido na densificação com o aumento da compactação. 


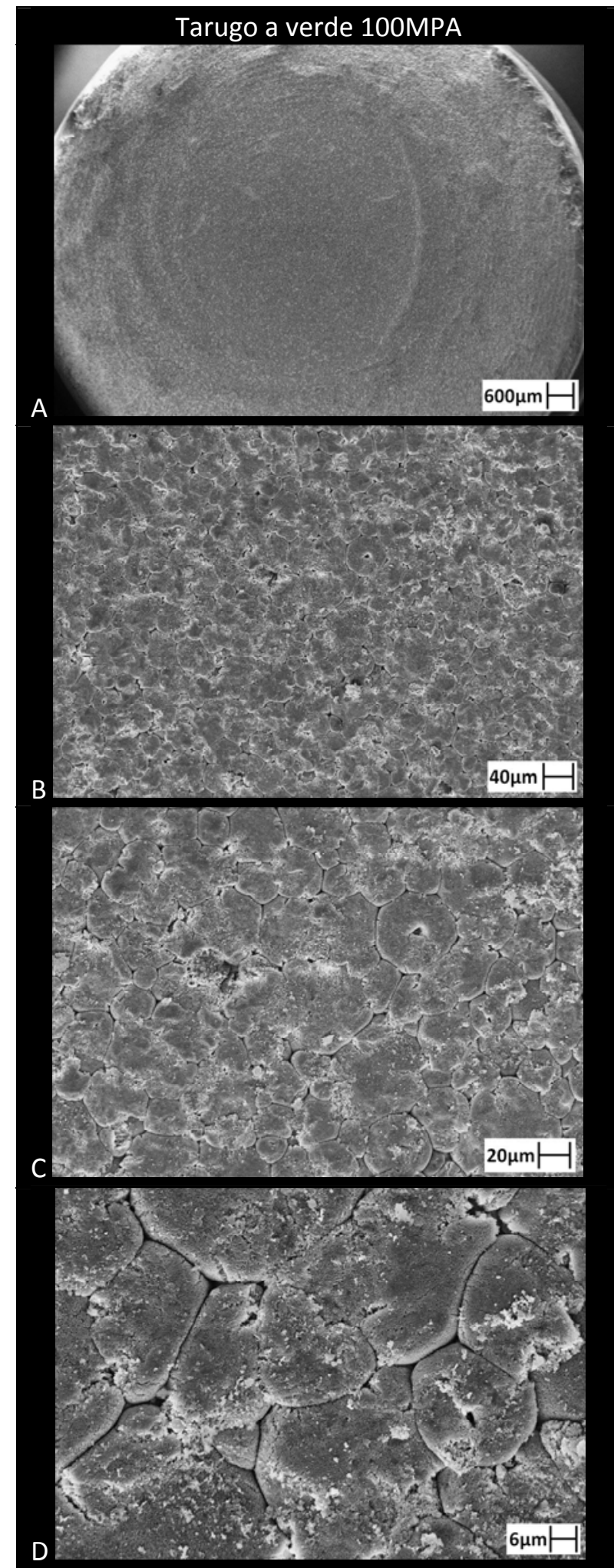

Figura 37 - Ampliação do tarugo de alumina verde em $100 \mathrm{MPa}$ de compressão, em (A) imagem da massa cerâmica; em (B) a (D) imagens da massa cerâmica com maior magnificação.

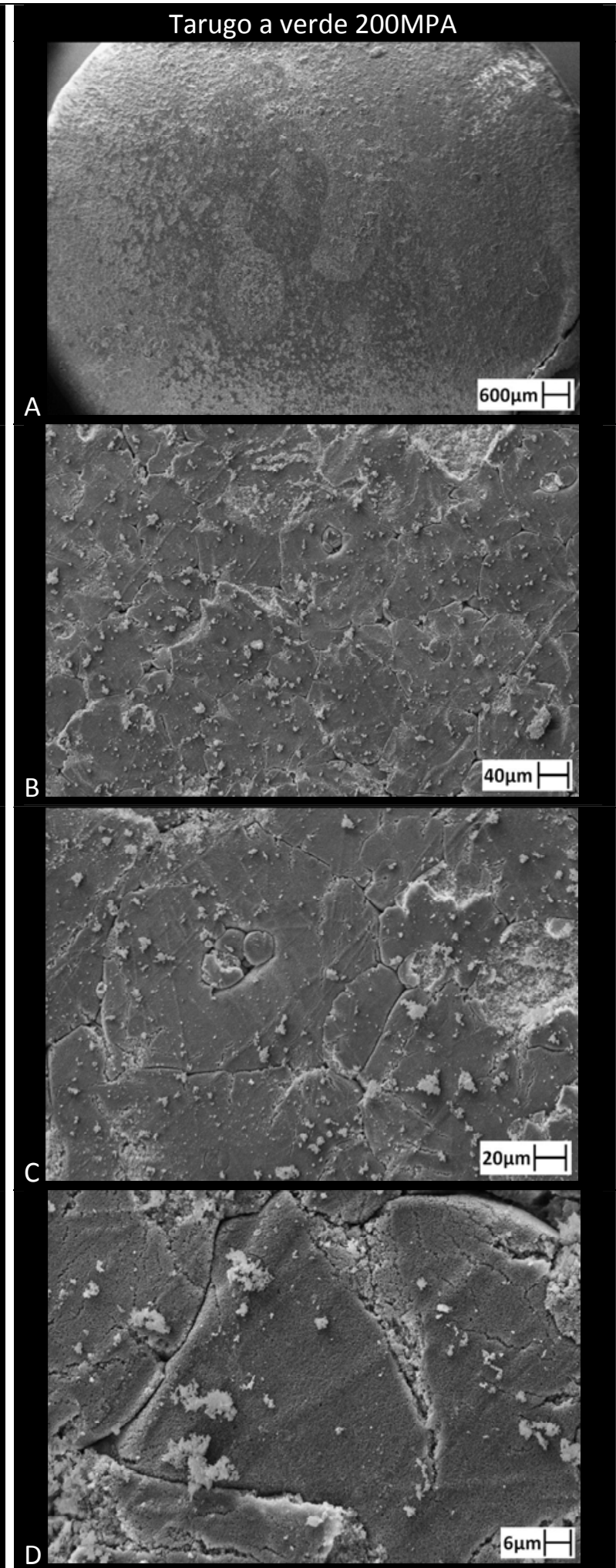

Figura 38 - Ampliação do tarugo de alumina verde em 200MPa de compressão, em (A) imagem da massa cerâmica; em (B) a (D) imagens da massa cerâmica com maior magnificação. 
As peças tratadas tiveram valor de resistência média de $398,67 \mathrm{MPa}$ para compressão de $200 \mathrm{MPa}$ e $325,51 \mathrm{MPa}$ para compressão de $100 \mathrm{MPa}$ enquanto que sem o tratamento se obteve $155,4 \mathrm{MPa}$, evidenciando a necessidade do tratamento térmico. Ressalta-se que a potência consumida para a usinagem da peça sem tratamento foi de $76,1 \mathrm{~W}$ e para a tratada $101,1 \mathrm{~W}$ a $1700 \mathrm{~W}$ para maior compressão, ou seja, as amostras não tratadas forneceram maior lubrificação (água adsorvida), porém a remoção foi intergranular com mais defeitos superficiais e chegou a empastar o rebolo; na tratada teve-se maior rigidez com remoção intragranular. $\mathrm{O}$ tratamento térmico acima da temperatura de transição vítrea $\left(T_{g} 87^{\circ} \mathrm{C}-89^{\circ} \mathrm{C}\right)$ do PVAl além de remover a umidade residual ainda aliviou a tensão residual do ligante (PVAl)

O gráfico da Figura 39, relativo ao ligante, nas amostras usinadas pós-prensagem (48 horas de repouso) e tratadas à $100^{\circ} \mathrm{C}$ por $12 \mathrm{hs}$. Comparou-se a resistência mecânica do mesmo material manipulado de três maneiras diferentes e com os mesmos parâmetros de usinagem $(0,5 \mathrm{~mm}$ de profundidade e avanço em $100 \mathrm{~mm} / \mathrm{min})$, em azul a resistência mecânica da peça a $100 \mathrm{MPa}$ sem tratamento térmico; em vermelho a peça foi prensada a $100 \mathrm{MPa}$ com tratamento térmico, e em verde comprimida a $200 \mathrm{MPa}$ e tratada termicamente.

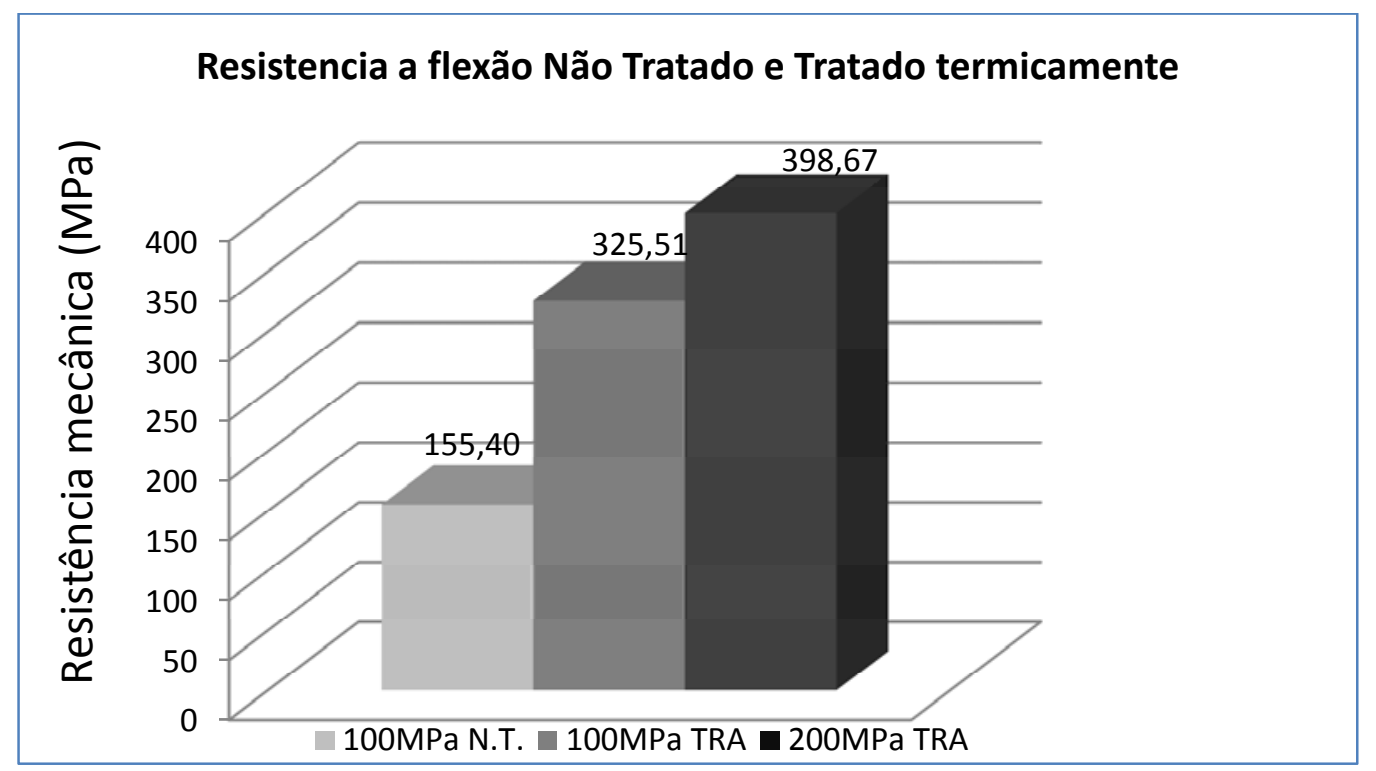

Figura 39 - Comparativo de resistência mecânica obtido por flexão a 4 pontos, para corpos de prova sinterizados tratados de maneiras diferentes.

A sinterização foi realizada em forno elétrico tipo câmara (Lindberg/Blue $M$ ), com as seguintes taxas de aquecimento: temperatura ambiente até $150^{\circ} \mathrm{C}\left(3,33^{\circ} \mathrm{C} / \mathrm{min}\right)$, de 150 até $600^{\circ} \mathrm{C}\left(4^{\circ} \mathrm{C} / \mathrm{min}\right)$, de $600^{\circ} \mathrm{C}$ até $1000^{\circ} \mathrm{C}\left(5^{\circ} \mathrm{C} / \mathrm{min}\right)$, de $1000^{\circ} \mathrm{C}$ até temperatura máxima $\left(6^{\circ} \mathrm{C} / \mathrm{min}\right)$, permanecendo na temperatura máxima por $2 \mathrm{~h}$; o resfriamento foi feito com as amostras no interior do forno até temperatura ambiente (Figura 40). 


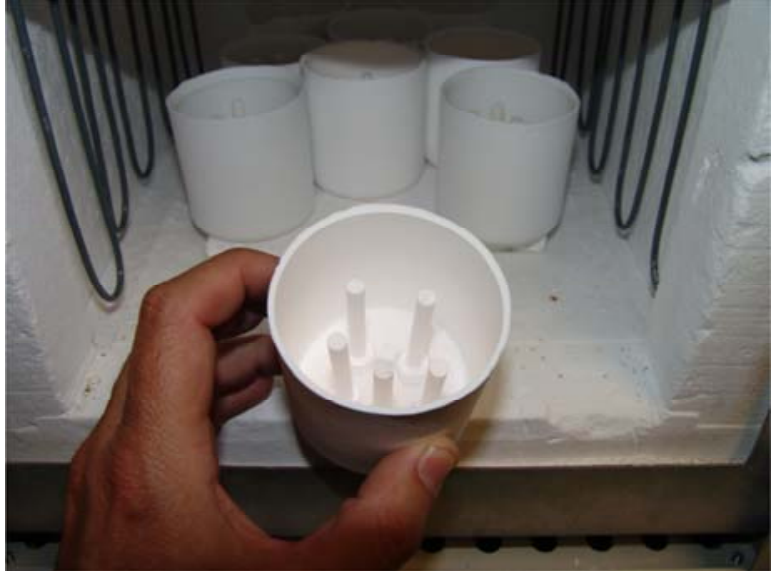

A

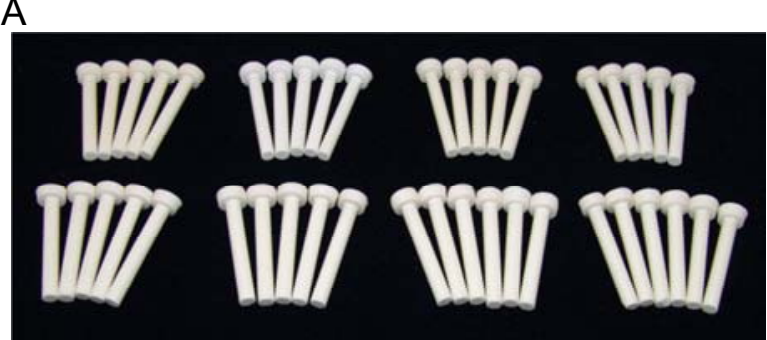

C

Figura 40 - Pinos usinados a verde e sinterizados em cadinhos de alumina, identificados em sua parte inferior. Em (A) vista de um cadinho no forno, em (B) vista com 9 cadinhos carregados com 5 amostras cada, em (C) vista das peças e em (D) um grupo de peças com identificação em sua base

A resistência mecânica pouco se alterou com o aumento da profundidade de corte. A Figura 41 mostra o gráfico comparativo da perda de resistência com o aumento da profundidade de corte utilizando os mesmos parâmetros de usinagem, menos de $3 \%$ na perda da resistência o que pode ser negligenciada, visto o erro desvio padrão. 


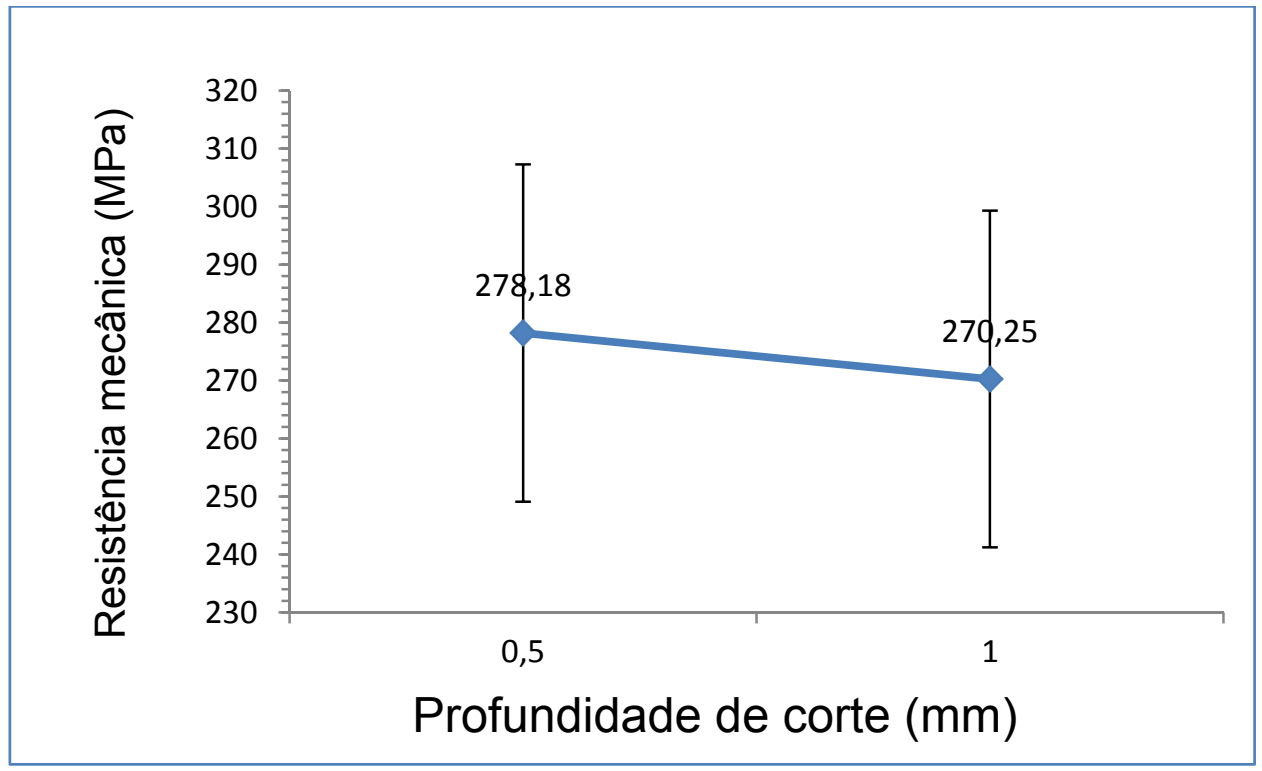

Figura 41 - Resistencia mecânica X profundidade de corte para corpos de prova prensados a 100MPa e sinterizados.

\subsection{Projeto do banco de usinagem}

Para a usinagem das amostras foi necessário um projeto adaptativo de um banco de ensaios existente, ilustrado na Figura 42, que apresentava uma excessiva vibração causada pelo Spindle rolamentado de 27.000RPM, que ao ser ligado gerava um "burst" de $70 \mathrm{G}$ e frequentemente quebrava o tarugo nesta simples operação.

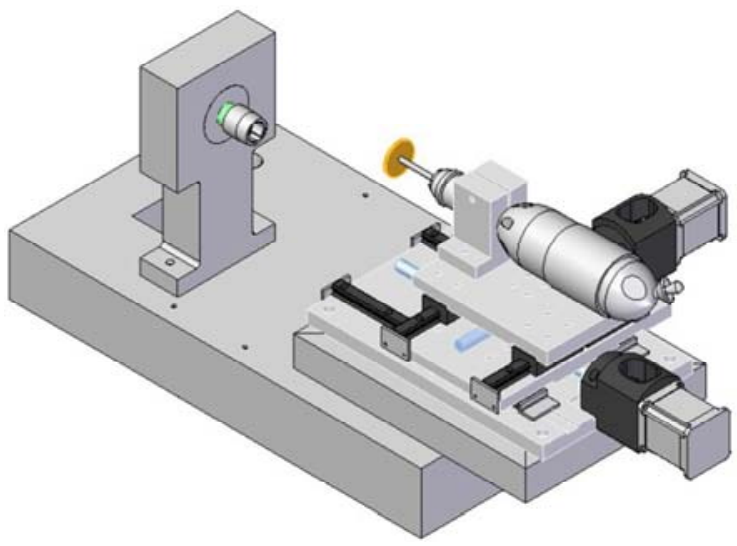

A Figura 42- Em (A) o primeiro projeto de maquina para usinagem a verde e $(B)$ o banco de ensaios inicial usado por Gambale (2008);

A solução encontrada foi fixar o Spindle na base Figura 43 (C) e (D) e movimentar o corpo de prova que tem rotação prevista de 200 a 1000RPM acionado por um servo motor e utilizando guias lineares de esferas recirculantes para o deslocamento, assim obtendo o menor nível possível de vibração no conjunto. Um protótipo de rápida montagem foi 
proposto Figura $43(\mathrm{~A})$, nele sobre uma base de ferro fundido cinzento com "slots" em T foi transferida a mesa XY do projeto Gambale 2008 e sobre ela montada o porta ferramentas Figura 44 (A), e um suporte para o Spindle de liga de alumínio 5052 Figura 43 (C), e em Figura 43 (B) é visto o protótipo montado e em (D) uma vista em detalhe do Spindle-reboloporta-ferramenta.

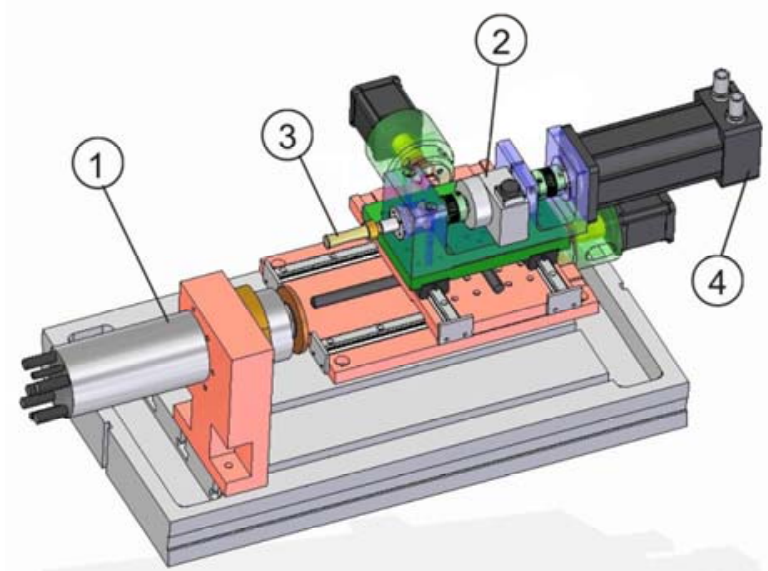

A

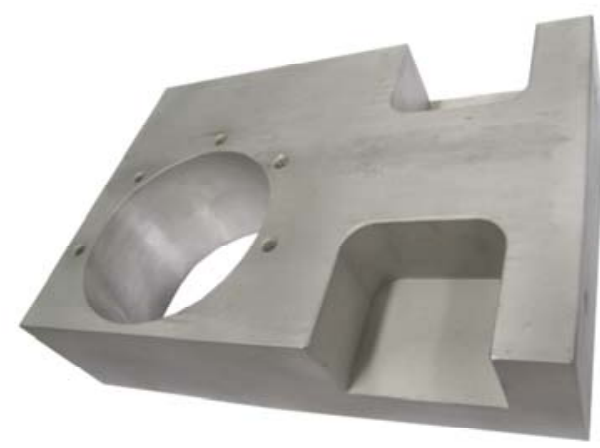

C

Figura 43 - Em (A) o projeto adaptativo da maquina de usinagem a verde sendo (A) (1) Spindle, (2) Sensor de torque, (3) Blank e (4) Servo motor, em B) o protótipo funcional, em (C) o suporte do Spindle e em (D) uma vista em detalhe do conjunto.

O porta ferramenta, Figura 44, foi desenvolvido para fornecer torque muito superior à operação e conter um torquímetro entre o sistema motor e o tarugo bruto. A operação deve manter a rotação com variação inferior a $0,5 \%$. Foi aplicado o Sensor de Torque MKDC-5 de capacidade máxima de $5 \mathrm{~N}$.m da MK Controle e Instrumentação Ltda e ServoMotor (WEG SWA56-2,5-20) com Servo-Conversor (WEG SCA050004). Para controle e aquisição dos dados em tempo real de usinagem foi aplicado módulo e aquisição de dados USB-6009 (14 BITS de resolução) da National Instruments Brazil Ltda. O servomotor e o sensor de torque são controlados através do software Labview pela interface National Instruments. Outra medida importante, foi acionar o servo motor do porta ferramentas em 
rampa para não comprometer a integridade estrutural do Blank na partida do motor, acelerando progressivamente até 600RPM.
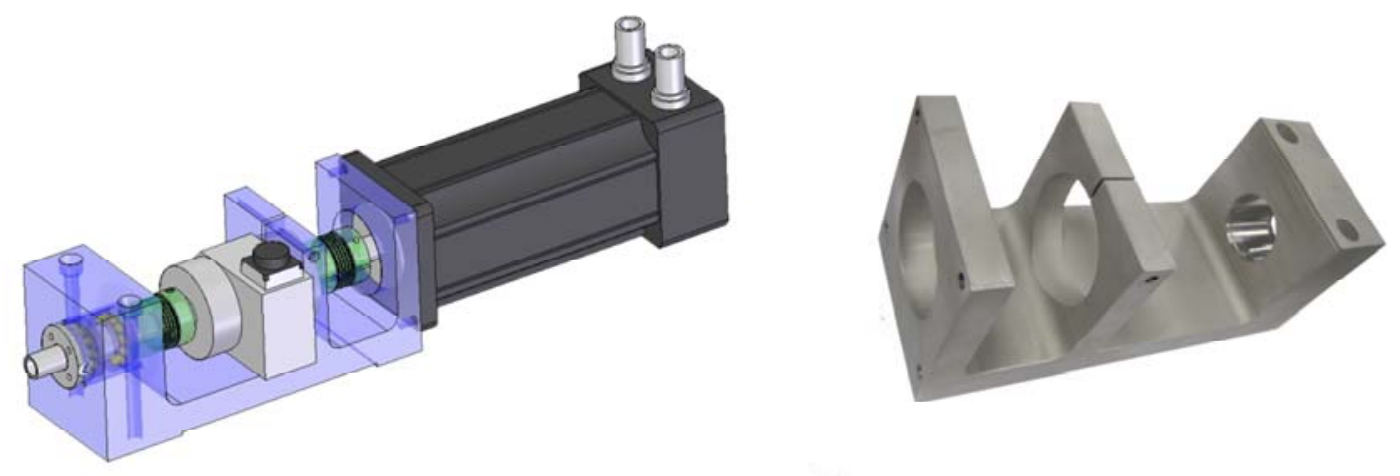

A

B
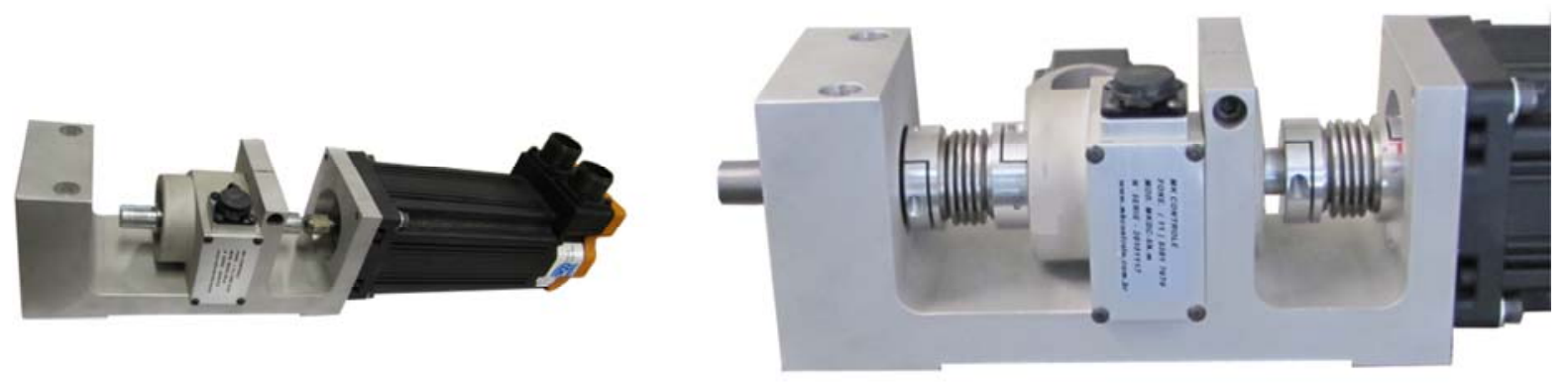

C

D

Figura 44 - Porta ferramentas e suporte para fixação do Spindle, em (A) o projeto feito em CAD, em (B) o suporte do porta ferramenta usinado, em (C) e (D) a instalação dos componentes do porta ferramentas.

Toda a estrutura da máquina foi usinada na oficina mecânica na EESC-USP. Foi desenvolvida uma estrutura em liga de alumínio 5052 para acomodar o servo motor juntamente ao sensor de torque e o eixo no qual se fixa o corpo de prova, sendo ambos conectados através de acoplamentos elásticos para corrigir possíveis imperfeições no alinhamento dos eixos Figura 44 (D). Para o acionamento do Spindle aerostático, a recomendação do fabricante exige que o ar comprimido seja triplamente filtrado a 5, 0,3 e

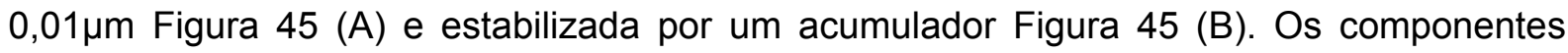
foram fixados em uma base de ferro fundido Figura 43 (B), para sustentar todos os componentes. 

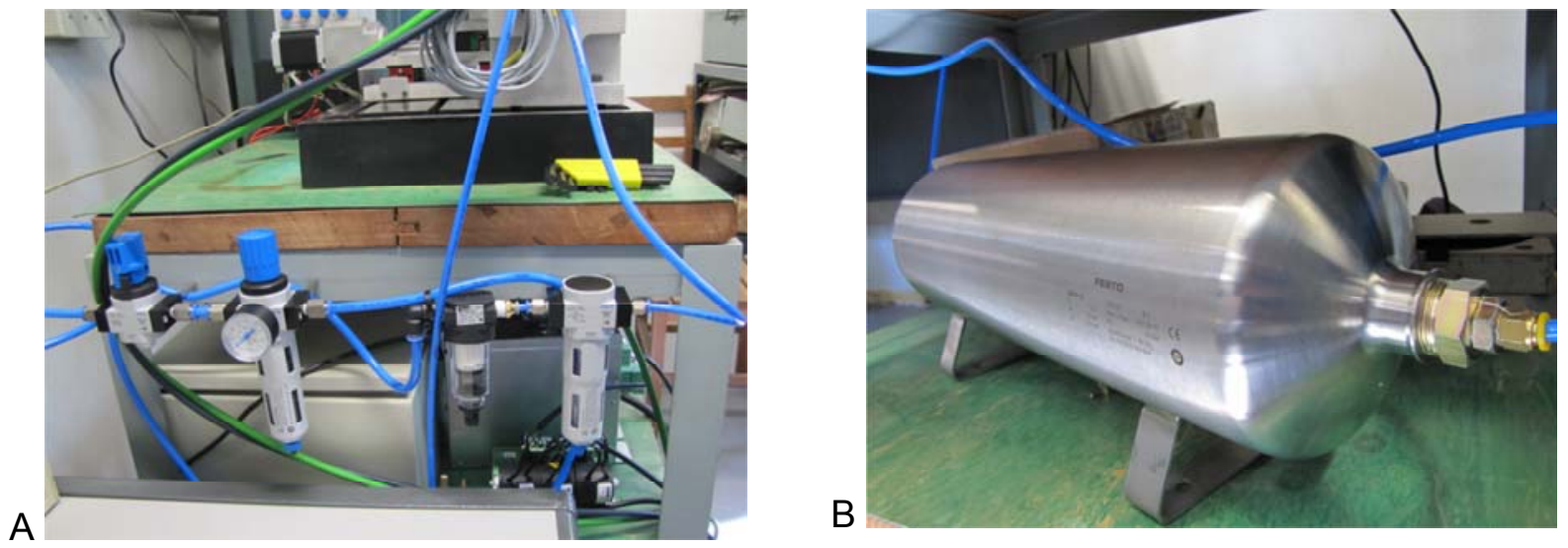

(6) (7)

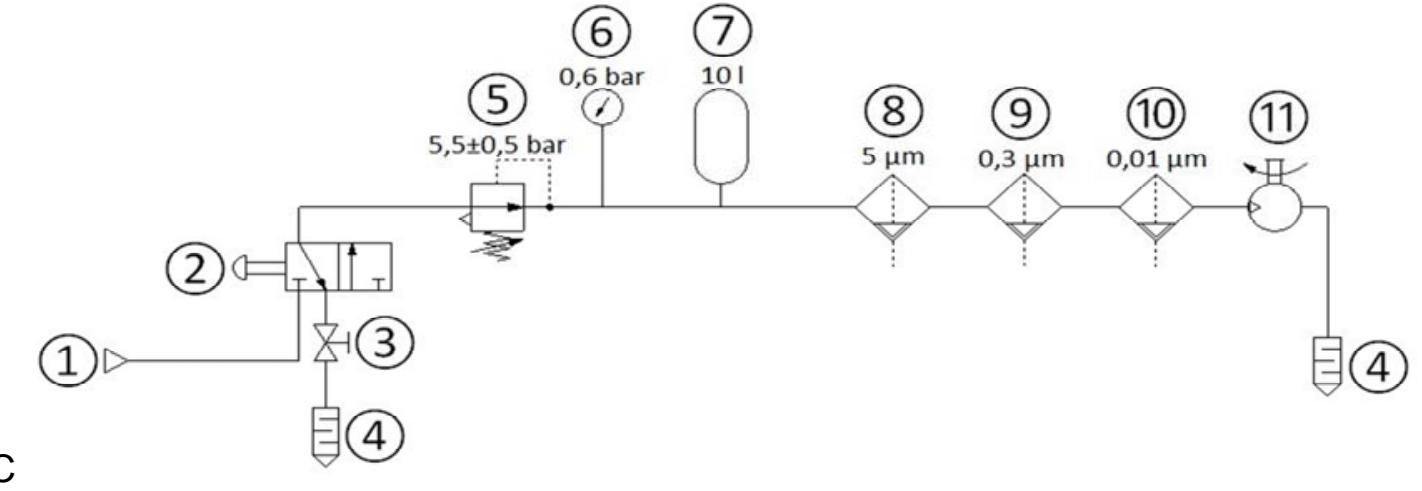

Figura 45 -Circuito de ar comprimido para alimentação do Spindle aerostático - em (A) circuito de filtragem do ar para o Spindle, em (B) acumulador, e em (C) Diagrama para pressurização do Spindle - (1) entrada de ar, (2) válvula direcional, (3) válvula, (4) silenciadores, (5) regulador de pressão, (6) manômetro, (7) acumulador, (8) a (10) filtros de ar e em (11) Spindle aerostático.

O cabeçote de usinagem (Spindle) aplicado foi o dicing Spindle D05716/3 de 2,4kW produzido pela LoadPoint bearings Limited (UK), instrumentado por Drive (interface de controle de do cabeçote) de 20amp capaz de operar com rotações de até 480.000rpm de motores síncronos e assíncronos e portas de entradas RS232 e USB (Drive System SD2S SIEB \& MEYER AG ); sistema de compensação para o cabeçote motor choke $11 \mathrm{~A} 350 \mu \mathrm{H}$ ) e TEST BOX (Unidade de controle manual) (SIEB \& MEYER AG).

Os rebolos foram fabricados sob encomenda pela Norton (Saint Gobain Abrasivos Ltda). A especificação técnica para usinagem à verde, onde a dressagem é feita com ponta única de diamante e sem refrigeração: Rebolo Reto 75X6X19 $38 \mathrm{~A} 80 \mathrm{IVH} \quad 45 \mathrm{~m} / \mathrm{s}$, onde os índices representam o diâmetro externo $(\varnothing e)=70 \mathrm{~mm}$; furo $(\varnothing \mathrm{i})=19 \mathrm{~mm}$ e espessura $(e)=6 \mathrm{~mm}$; I-dureza moles; V- vitrificado; $\mathrm{H}$ - denominador industrial (Norton); 38A- Branco de alumina eletrofundida branca de dimensão 80 Mesh dureza media ideal para trabalho médio-desbaste/acabamento.

A ponta dressadora aplicada foi a diaform lapidada de um monocristal natural de diamante, fabricada pela Master Diamond com ângulo de lapidação da ponta de $40^{\circ}$ e raio 
de $0,5 \mathrm{~mm}$. O dressador foi posicionado a $45^{\circ}$ com altura centrada ao do rebolo e dressada a face de corte e superfície periférica. As condições de dressagem por passe foram: profundidade $0,05 \mathrm{~mm}$, avanço $100 \mathrm{~mm} / \mathrm{min}$, rotação do eixo arvore $1000 \mathrm{rpm}$.

Para o controle dos motores de passo e interface com microcomputador, decidiu-se utilizar no projeto uma placa controladora pertencente ao kit: "4 axis HobbyCNC PRO Ver1 Driver Board Kit" Figura 46, que foi montada na execução do projeto, devido ao baixo custo e versatilidade deste componente [US\$95,00], e para comandar a placa foi utilizado o software Turbo CNC 5.0, de uso gratuito até 100 linhas de programação..

A tensão de alimentação da placa varia entre $12 \mathrm{~V}$ e $42 \mathrm{~V} \mathrm{DC}$ e a corrente que alimenta os motores de passo deve ser ajustada antes que estes sejam conectados. Outra característica da placa é que ela só pode ser usada com motores de passo do tipo unipolar. A Figura 46 mostra o seus componentes, a placa montada com dissipador para resfriamento, bornes de entrada de tensão, luz sinalizadora de alimentação ativa e terminais de saída de seis pinos para os motores de passo.

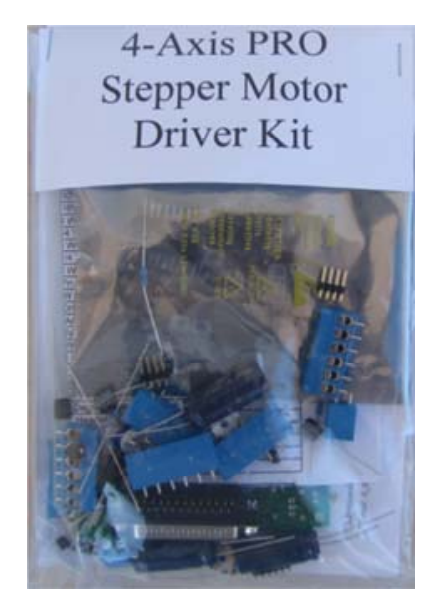

A

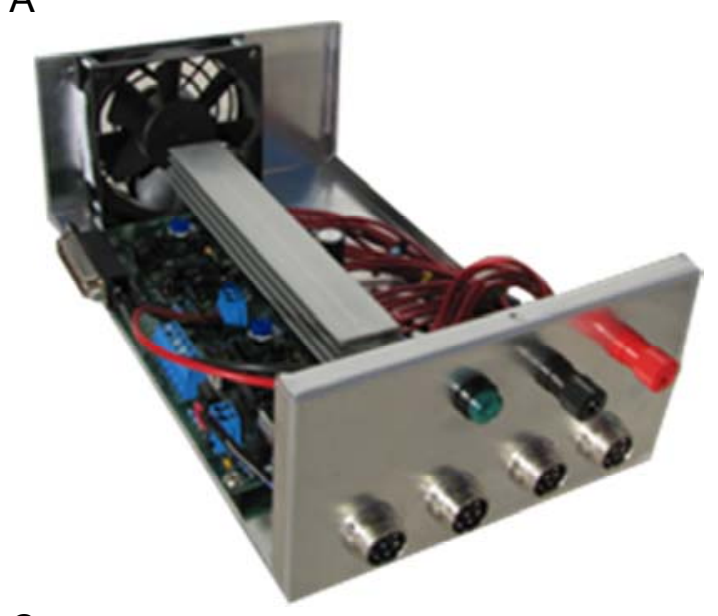

Figura 46 - Interface de controle de maquina CNC, em (A) o kit comercial, em (B) e o kit montado e em (D) e (D) o driver completo pronto para controlar os motores de passo. 
A tabela 5 apresenta todo investimento aplicado na fabricação do protótipo de usinagem.

Tabela 5 - Investimento praticado no protótipo do banco de ensaios, excetuado mão de obra do SEM-EESC-USP.

\begin{tabular}{|l|c|c|c|}
\hline \multicolumn{1}{|c|}{ Componentes } & Qde & $\begin{array}{c}\text { Adquirido } \\
\text { R\$ }\end{array}$ & $\begin{array}{c}\text { Reuso } \\
\text { R\$ }\end{array}$ \\
\hline Spindle LoadPoint com custos de importação & 1 & 21670,00 & \\
\hline $\begin{array}{l}\text { Modulo de aquisição de dados usb-6009 (pn } \\
\text { 191039d-01I) com 14 bits de resolução e } \\
\text { amostragem de sinais de 48ks/s. Inclui cabo usb } \\
\text { (pn 192256a-01) de 1m e software ni-daqmx (pn } \\
\text { 779461t-01). }\end{array}$ & 1 & 1109,28 & \\
\hline Servo motor weg SWA40-2.6-30 & 1 & 2050,00 & \\
\hline Servo-conversor WEG SCA050004t2223 psz2 & 1 & 2030,00 & \\
\hline Cabo de resolver - WEG CR 4x0.75 3mts & 1 & 365,00 & \\
\hline $\begin{array}{l}\text { Cabo de potência WEG CP 4x0.75 3mts com } \\
\text { blindagem }\end{array}$ & 1 & 201,00 & \\
\hline Sensor de torque MKDC-5 & 1 & 3260,00 & \\
\hline $\begin{array}{l}\text { Acoplamentos bellows ou beam para torque de 3 } \\
\text { Nm (diâmetro 32mm x L32mm) }\end{array}$ & 2 & 230,00 & \\
\hline Rolamentos esféricos de contato angular & 2 & 169,00 & \\
\hline Sistema pneumatico & 1 & 3584,00 & \\
\hline Mesa XY com driver e fonte & 1 & & 3900,00 \\
\hline Base em Ferro fundido com slotes em “T" & 1 & & 2000,00 \\
\hline Sistema de refrigeração a água & 1 & 40,00 & \\
\hline Rebolo reto 75x6x19 38a80 IVH 45m/s & 22 & 366,52 & \\
\hline Materiais Gerais & 1 & 1000,00 & 500,00 \\
\hline Computador & 1 & 1500,00 & \\
\hline Caixas, fios, parafusos, fontes e materiais elétricos & 1 & 800,00 & \\
\hline Aspirador de pó & & & $\mathbf{6 . 5 9 6 , 0 0}$ \\
\hline \multicolumn{1}{|c|}{ Total parcial } & $\mathbf{3 8 . 3 7 4 , 8 0}$ & \\
\hline & & & \\
\hline
\end{tabular}

Um banco de aquisição dados experimentais definitivo foi projetado para medir as forças de corte através da medida de torque de usinagem (Figura 47). Neste a estrutura será em granito sintético, a mesa $X Y$ será fabricada em aço SAE-1020 que tem menor coeficiente de espansão térmica $\left(13 \times 10^{-6} \mathrm{~m} / \mathrm{m}^{\circ} \mathrm{C}\right)$ e maior modulo elástico (210GPa) que o alumínio $\left(25 \times 10^{-6} \mathrm{~m} / \mathrm{m}^{\circ} \mathrm{C}\right.$ e $70,3 \mathrm{GPa}$ respectivamente) e cada eixo será acionado por servo motores com $2,4 \mathrm{~N}$ de torque contra os $1,8 \mathrm{~N}$ dos motores de passo anteriormente utilizados, será dotado de uma proteção em acrílico para retenção do pó e segurança do operador. 


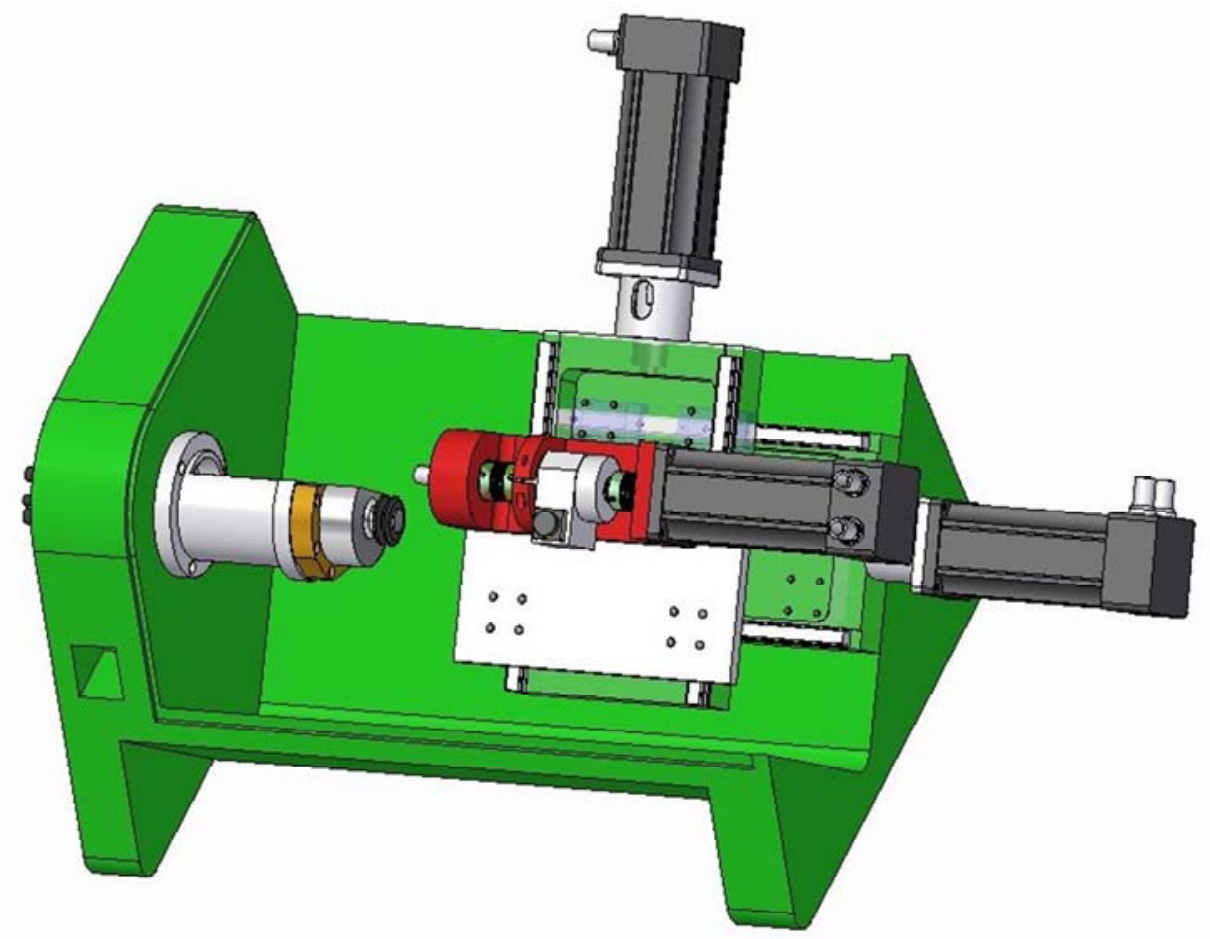

A

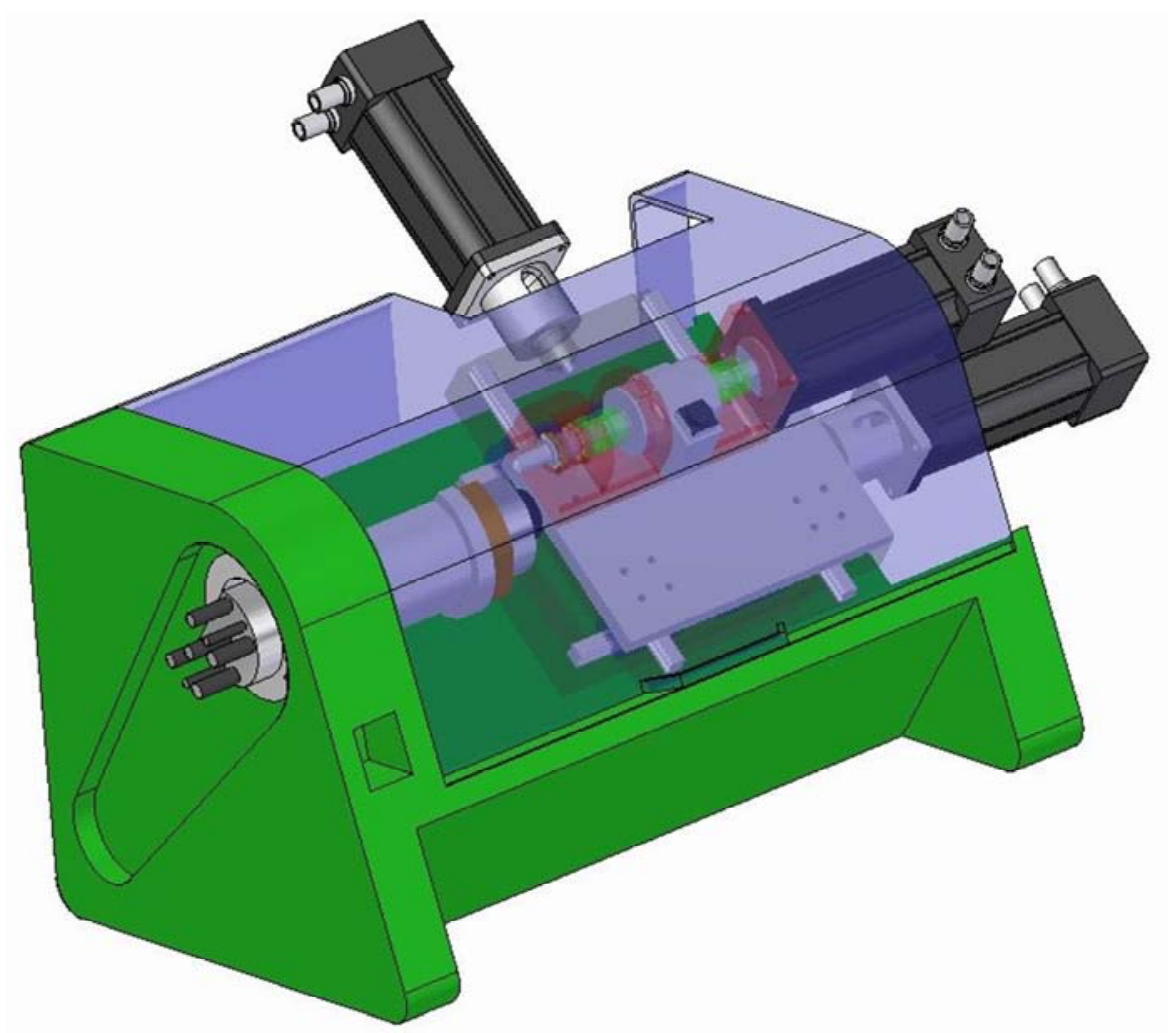

B

Figura 47 - Em (A) e (B) Projeto virtual do banco conceitual feito em estrutura de granito sintético, com acionamento dos eixos $X Y$ através de servo-motores e equipado com Spindle aerostático. 


\subsection{Usinagem dos corpos cerâmicos}

$\mathrm{Na}$ sequência das Figuras 49 a 56, são mostradas imagens das superfícies usinadas a verde sem sinterização, seguidas de imagens de microscopia de varredura eletrônica do devido cavaco a cada parâmetro de usinagem. Os dados coletados através do LABVIEW geraram uma lista de pontos de tempo versus torque e se concentrou os últimos dois passes de usinagem. Considerou-se a média dos picos máximos de corte excluída da média do toque em vazio (recuo do porta ferramenta).

A medida de torque foi tomada a partir da média dos pontos da parte inferior do gráfico (Torque $X$ Tempo) obtido pelo sensor de torque, adotada como região de repouso e sobre a média dos 5 maiores picos de torque (Figura 48), é presumido que os picos de tensão são os responsáveis pela introdução de defeitos críticos.

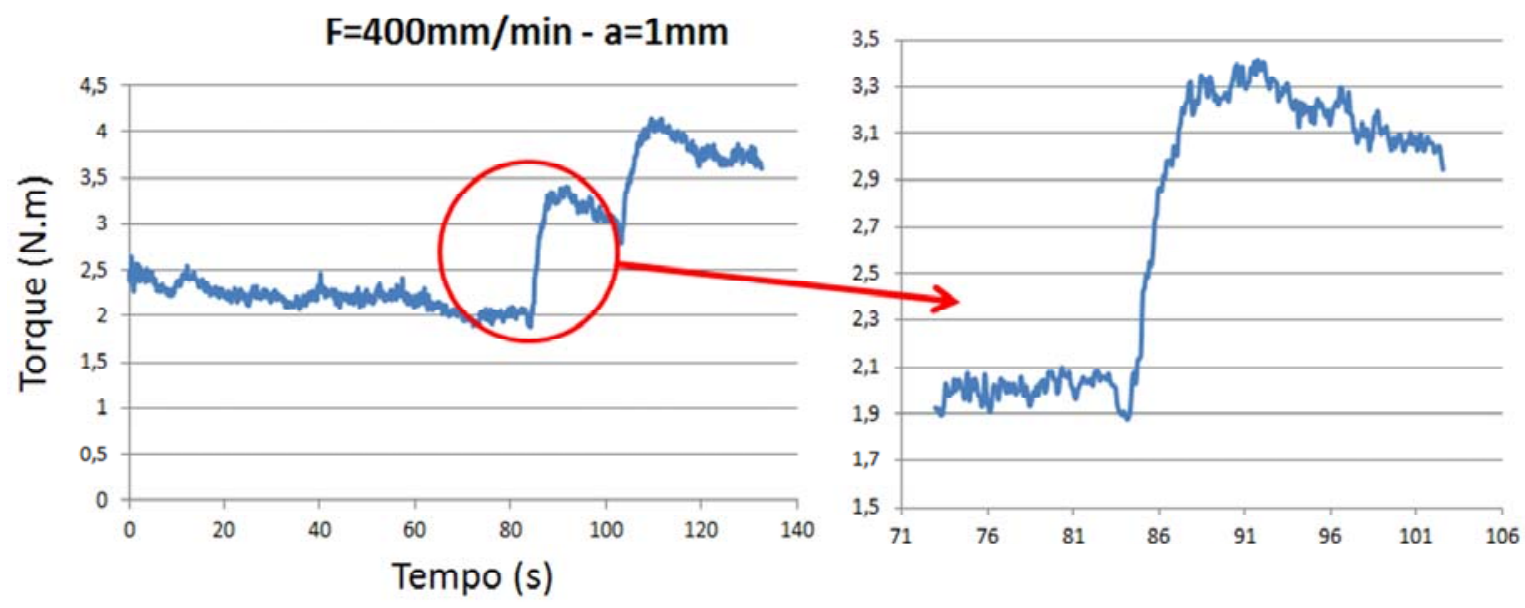

Figura 48 - Gráfico de Torque X Tempo, a media dos pontos mais baixos representa o repouso e a media dos 5 maiores pontos, o torque máximo.

Devido a partículas semi-desprendidas na superfície do rebolo, que é comum na dressagem em liga vítrea, Figuras 49 a 56 item (A), facilitou a visualização e consequentemente a interpretação da melhoria na qualidade superficial na usinagem a verde com o aumento da velocidade de avanço da ferramenta, foi notado uma distribuição de riscos com menor profundidade nas peças usinadas em condições de corte mais agressivas, comprovado pela diminuição do tamanho dos cavacos observados nos itens (B) e (C) e pelo comparativo da resistência mecânica Figuras 49 a 56, item (D) realizado por ensaio de flexão a 4 pontos das amostras sinterizadas, no qual se constatou uma pequena perda de resistência com o aumento do avanço. 


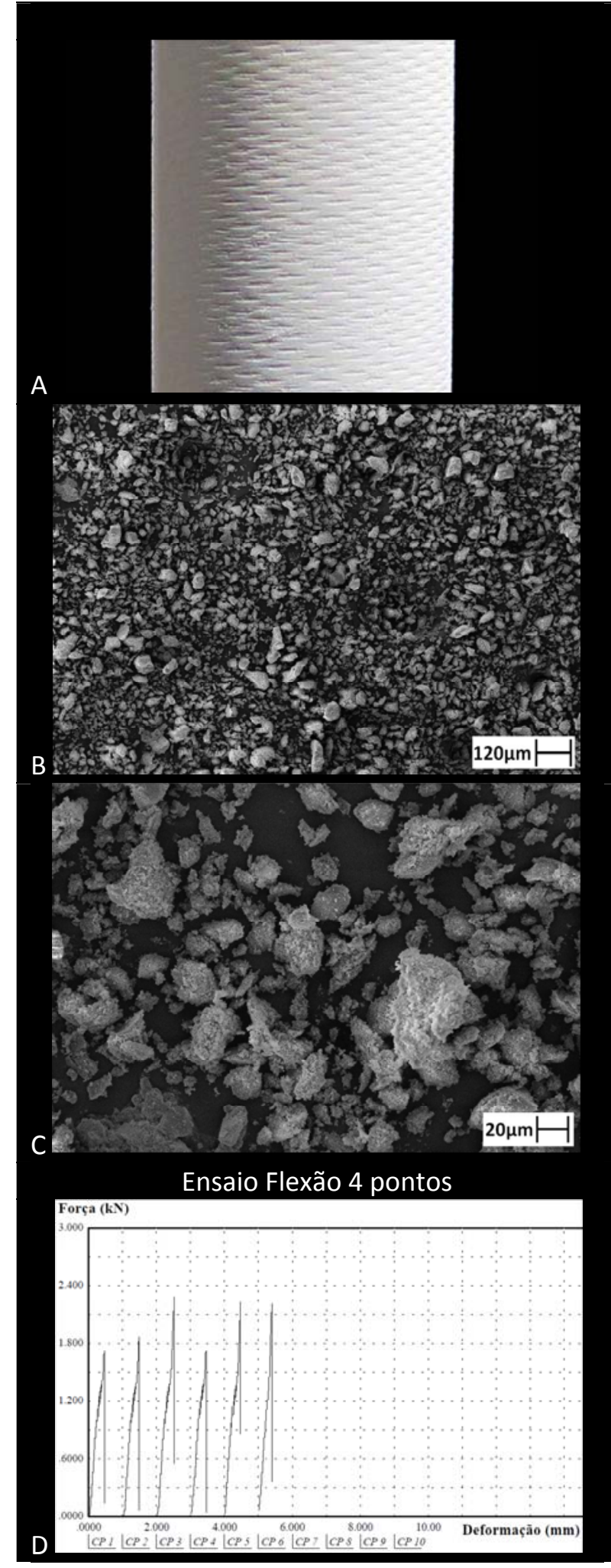

Figura 49 - Usinagem á verde $F=100 \mathrm{~mm} / \mathrm{min}$ e $A=0,5 \mathrm{~mm} \quad 100 \mathrm{MPa}$, em (A) superfície da amostra após usinagem, em (B) imagem da superfície por MEV, em (C) maior magnificação e em (D) gráfico do ensaio de flexão a quatro pontos após sinterização.

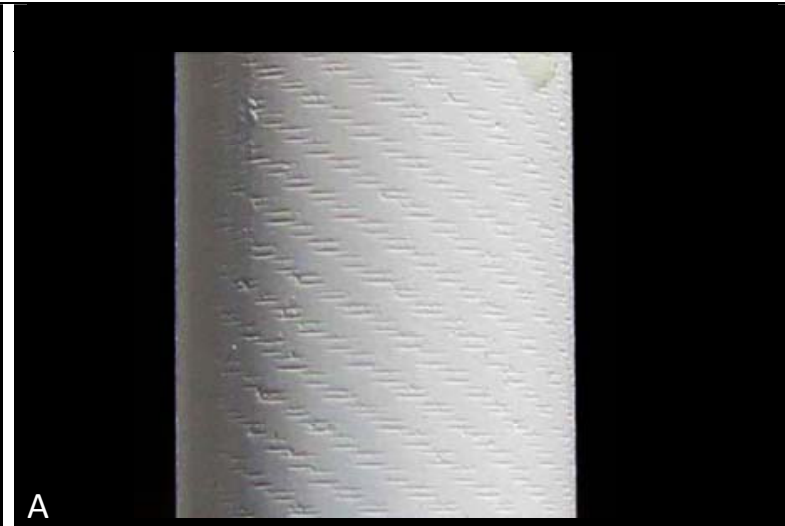

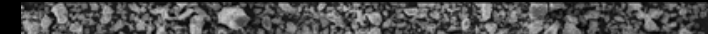
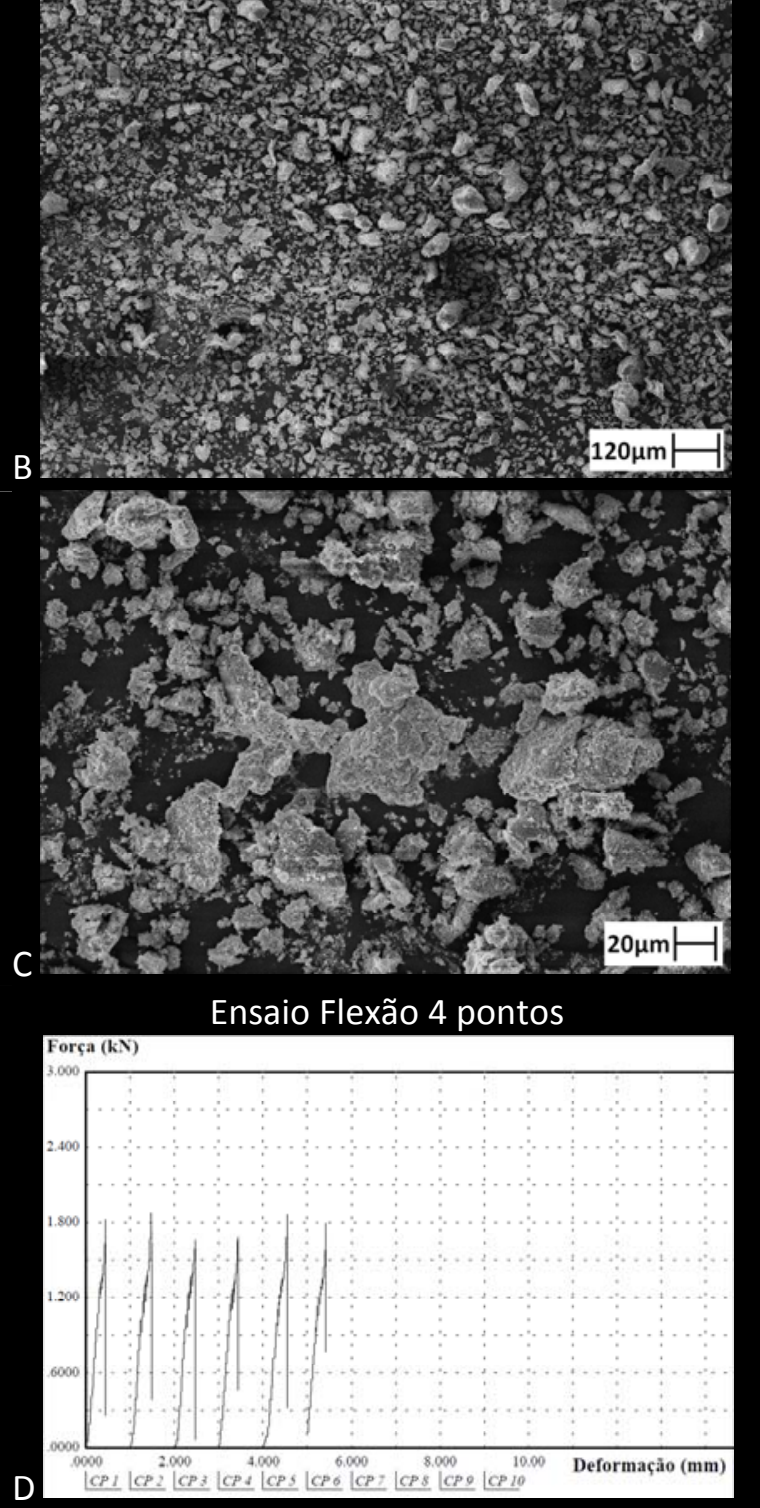

Figura 50 - Usinagem á verde $F=200 \mathrm{~mm} / \mathrm{min}$ e $A=0,5 \mathrm{~mm} \quad 100 \mathrm{MPa}, \quad$ em $\quad(A)$ superfície da amostra após usinagem, em (B) imagem da superfície por MEV, em (C) maior magnificação e em (D) gráfico do ensaio de flexão a quatro pontos após sinterização. 

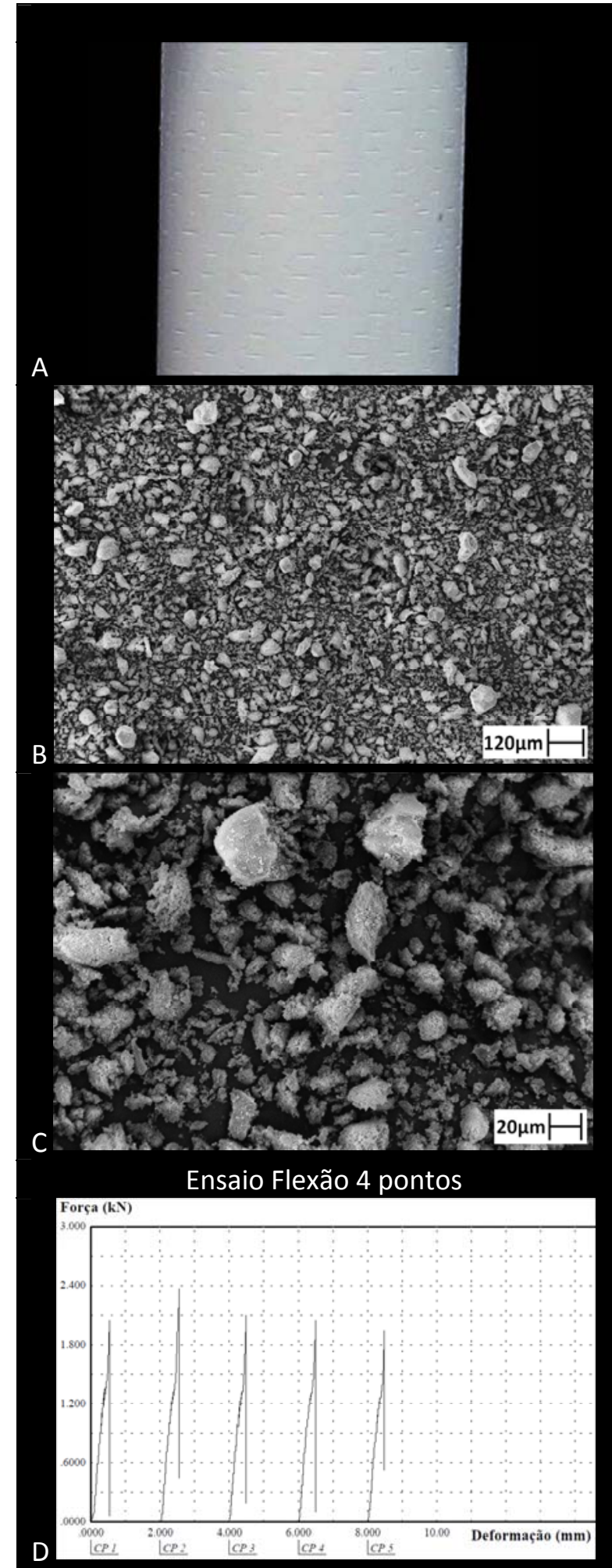

Figura 51 - Usinagem á verde $F=300 \mathrm{~mm} / \mathrm{min}$ e $A=0,5 \mathrm{~mm} \quad 100 \mathrm{MPa}, \quad$ em $\quad(A)$ superfície da amostra após usinagem, em (B) imagem da superfície por MEV, em (C) maior magnificação e em (D) gráfico do ensaio de flexão após sinterização.
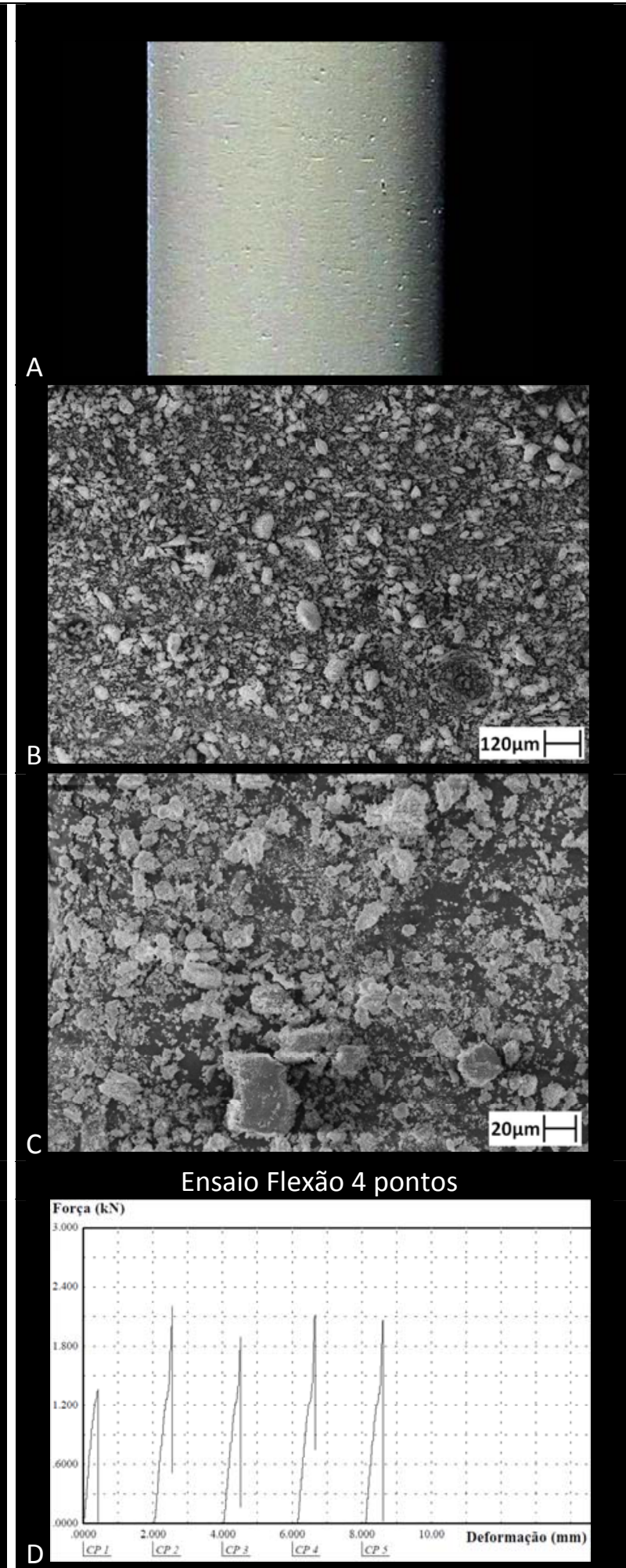

Figura 52 - Usinagem á verde $F=400 \mathrm{~mm} / \mathrm{min}$ e $\mathrm{A}=0,5 \mathrm{~mm} \quad 100 \mathrm{MPa}, \quad$ em $\quad(A)$ superfície da amostra após usinagem, em (B) imagem da superfície por MEV, em (C) maior magnificação e em (D) gráfico do ensaio de flexão após sinterização. 

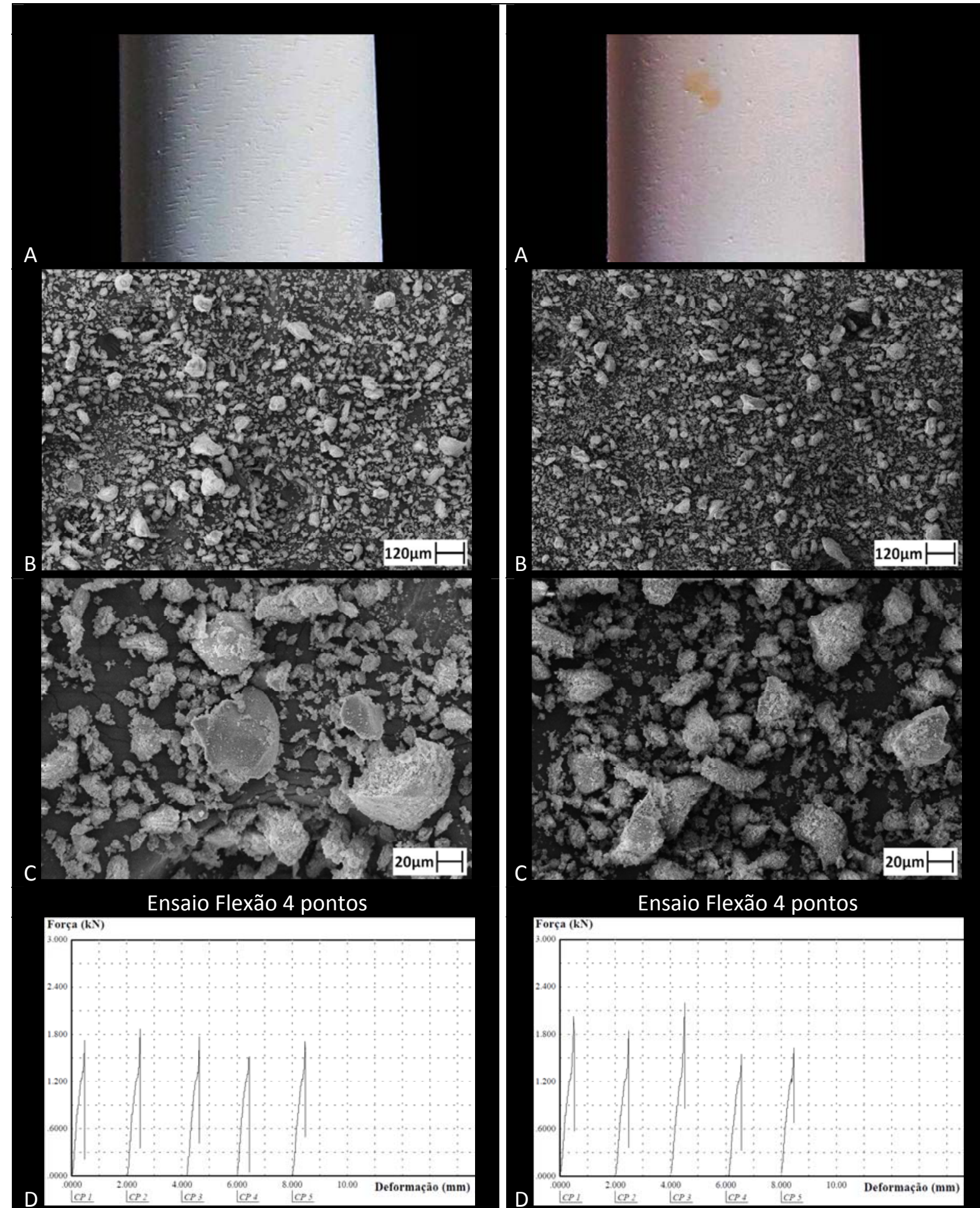

Figura 53 - Usinagem á verde $F=100 \mathrm{~mm} / \mathrm{min} \mathrm{e}$ $A=1 \mathrm{~mm} 100 \mathrm{MPa}$, em (A) superfície da amostra após usinagem, em (B) imagem da superfície por MEV, em
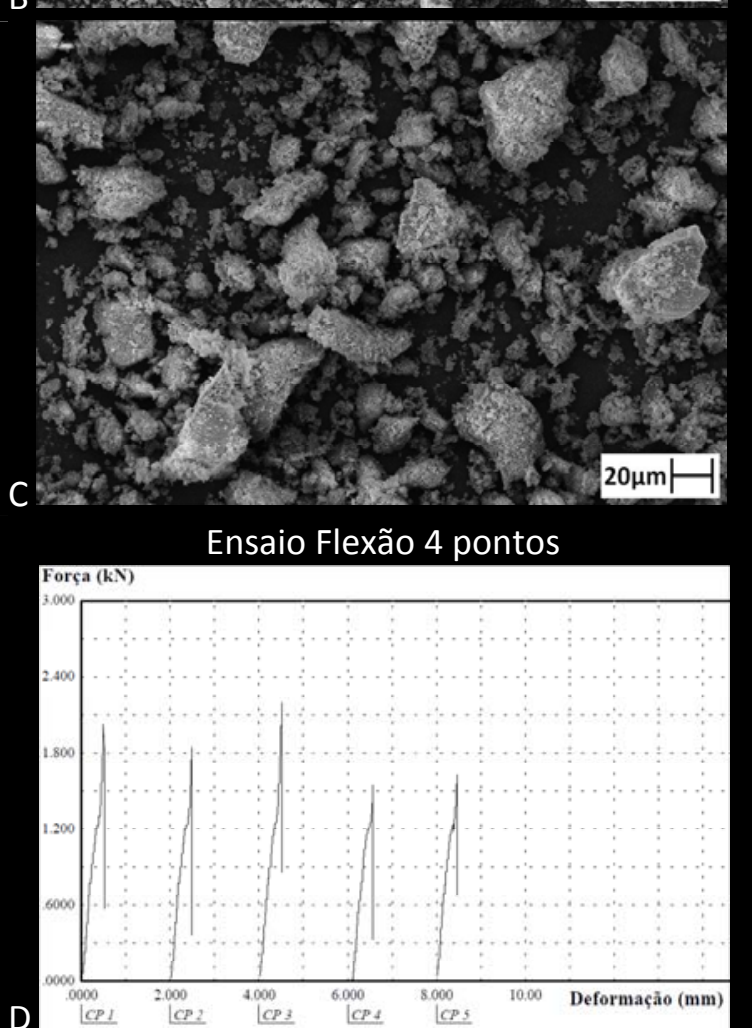

Figura 54 - Usinagem á verde $F=200 \mathrm{~mm} / \mathrm{min} \mathrm{e}$ $A=1 \mathrm{~mm} 100 \mathrm{MPa}$, em $(A)$ superfície da amostra após usinagem, em (B) imagem da superfície por MEV, em (Cc) maior magnificação e em (D) gráfico do ensaio de flexão após sinterização. gráfico do ensaio de flexão após sinterização. 

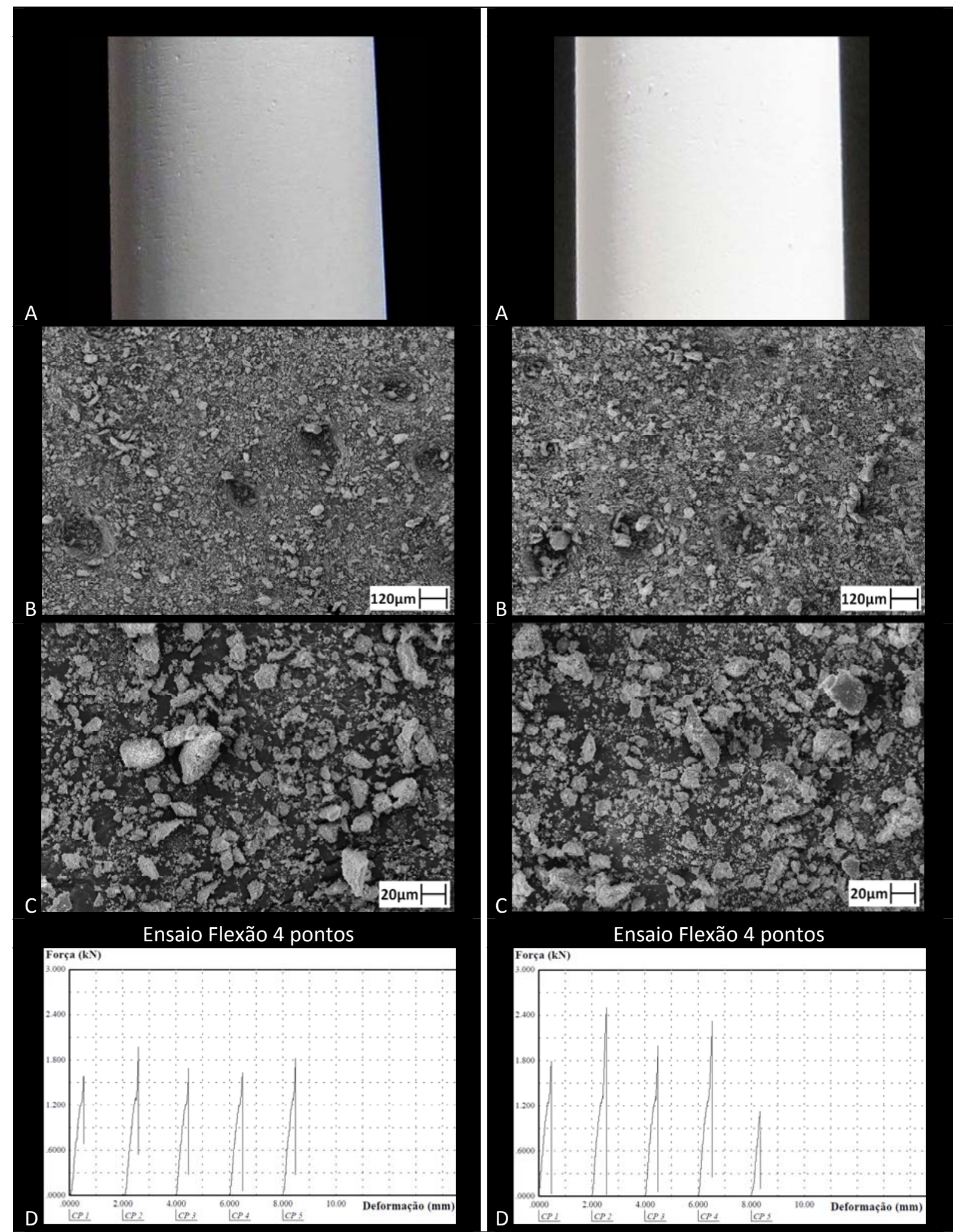

Figura 55 - Usinagem á verde $F=300 \mathrm{~mm} / \mathrm{min}$ e $A=1 \mathrm{~mm} \quad 100 \mathrm{MPa}$, em (A) superfície da amostra após usinagem, em (B) imagem da superfície por MEV, em (C) maior magnificação e em (D) gráfico do ensaio de flexão após sinterização.

Figura 56 - Usinagem á verde $F=400 \mathrm{~mm} / \mathrm{min}$ e $A=1 \mathrm{~mm} \mathrm{100MPa,} \mathrm{em} \mathrm{(A)} \mathrm{superfície}$ da amostra após usinagem, em (B) imagem da superfície por MEV, em (C) maior magnificação e em (D) gráfico do ensaio de flexão após sinterização. 
Riscos superficiais são concentradores de tensão, então com o aumento do avanço houve uma diminuição da profundidade e a densidade de riscos superficiais que foi responsável por uma parcela do aumento da resistência com o aumento do avanço.

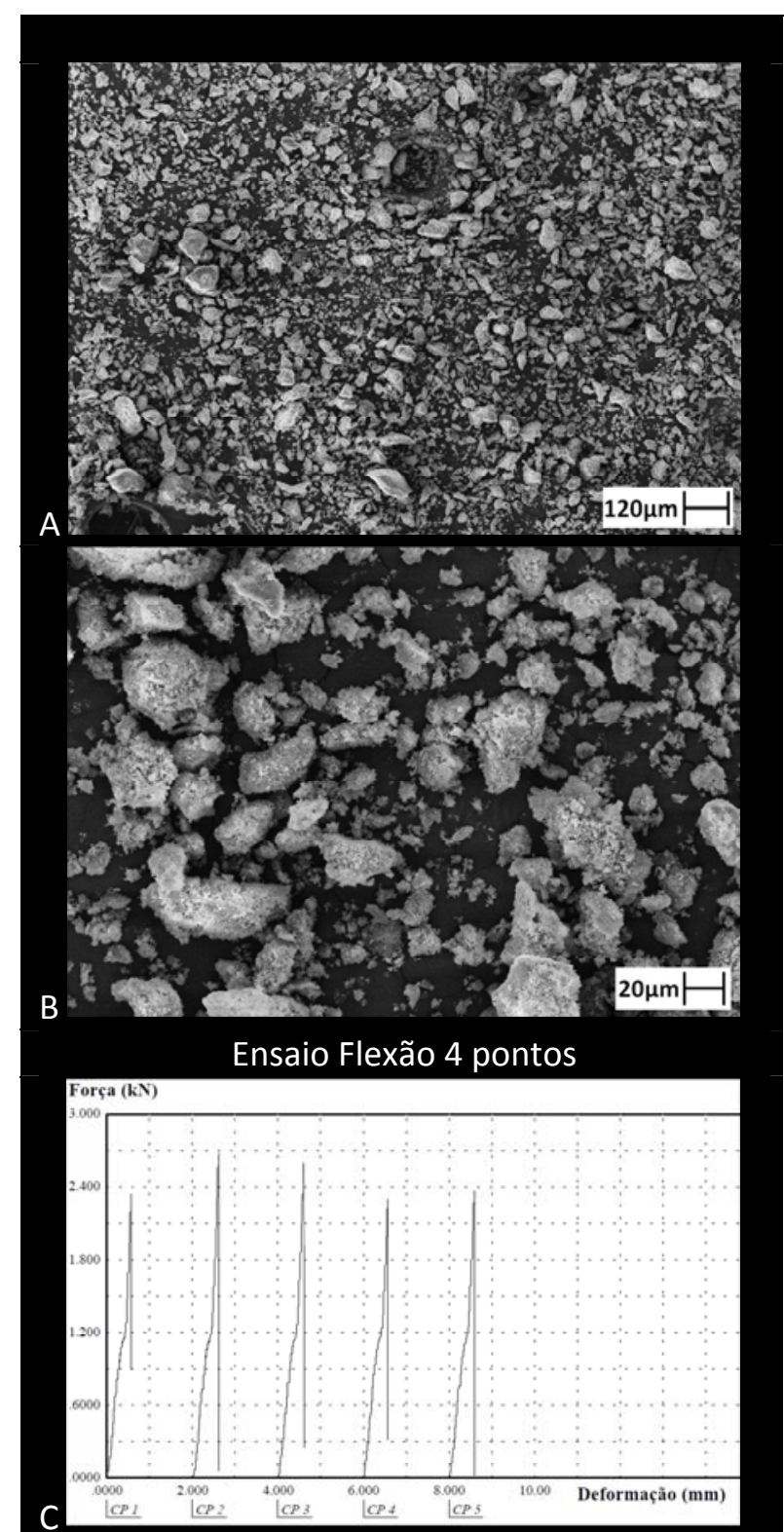

Figura 57 - Usinagem á verde $\mathrm{F}=100 \mathrm{~mm} / \mathrm{min}$ e $A=1 \mathrm{~mm} 200 \mathrm{MPa}$, em (A) imagem da superfície por MEV, em (B) maior magnificação e em (C) gráfico do ensaio de flexão a 4 pontos após sinterização.
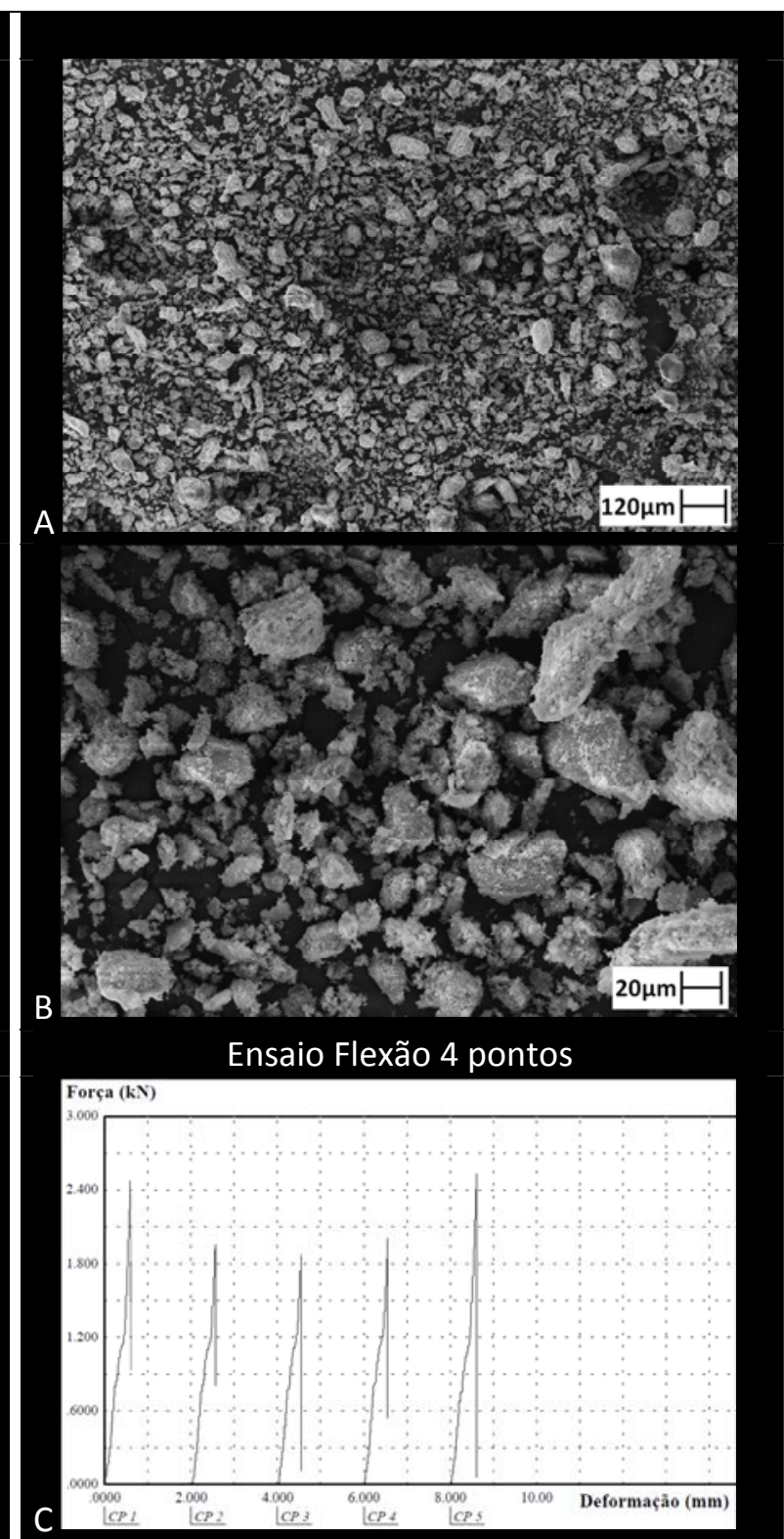

Figura 58- Usinagem á verde $\mathrm{F}=200 \mathrm{~mm} / \mathrm{min}$ e $A=1 \mathrm{~mm} 200 \mathrm{MPa}$ em (A) imagem da superfície por MEV, em (B) maior magnificação e em (C) gráfico do ensaio de flexão a quatro pontos após sinterização

Pelas Figuras 59 e 60 item (C), observa-se que em peças prensadas a $200 \mathrm{MPa}$ os cavacos se tornam menores que o a 100MPa na mesma condição de usinagem e com aspecto de superfícies menos rugosos típicas da fratura intragranular. 


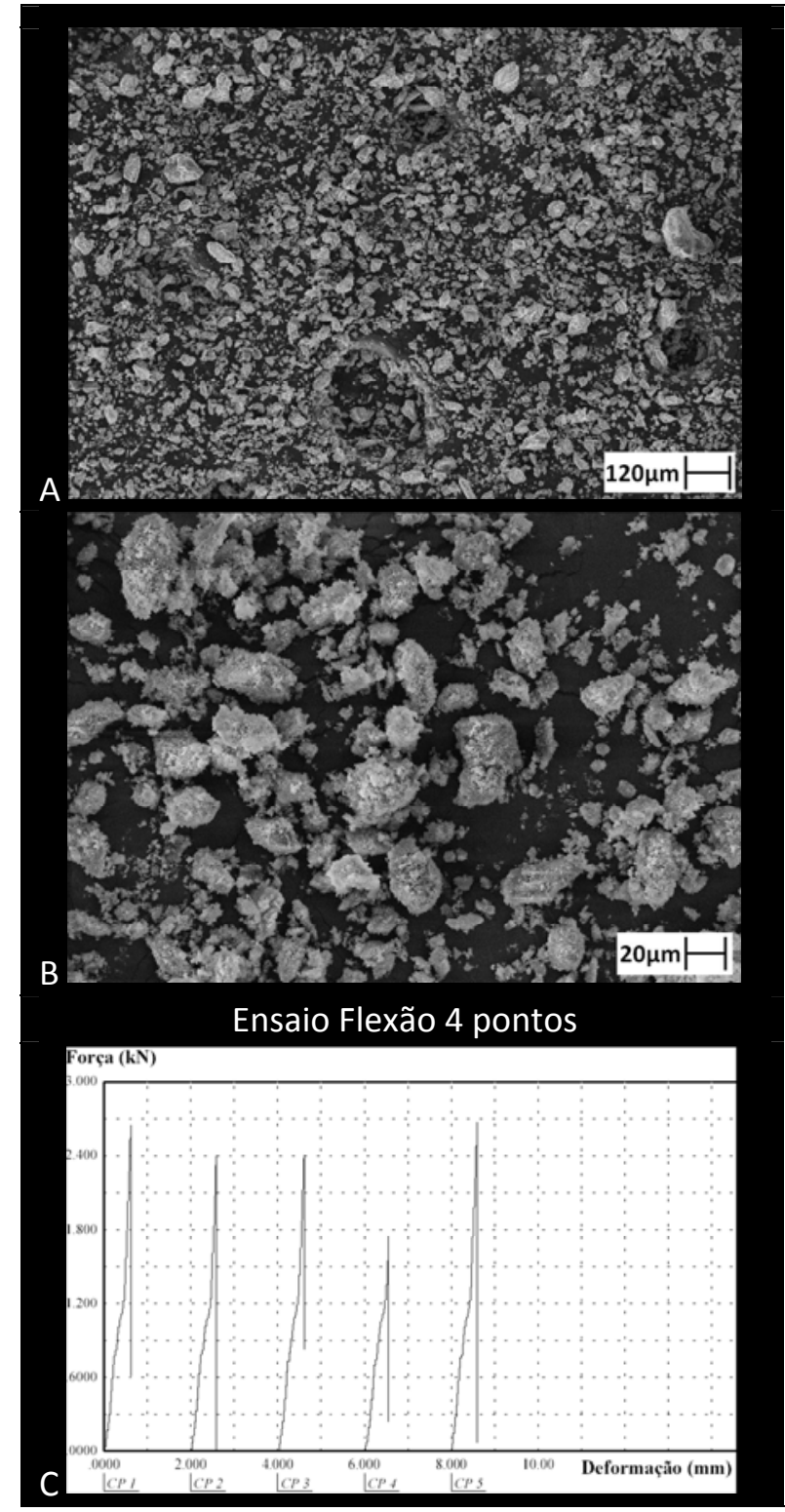

Figura 59 - Usinagem á verde $F=300 \mathrm{~mm} / \mathrm{min}$ e $A=1 \mathrm{~mm} 200 \mathrm{MPa}$, em $(A)$ imagem da superfície por MEV, em (B) maior magnificação e em (C) gráfico do ensaio de flexão a quatro pontos após sinterização

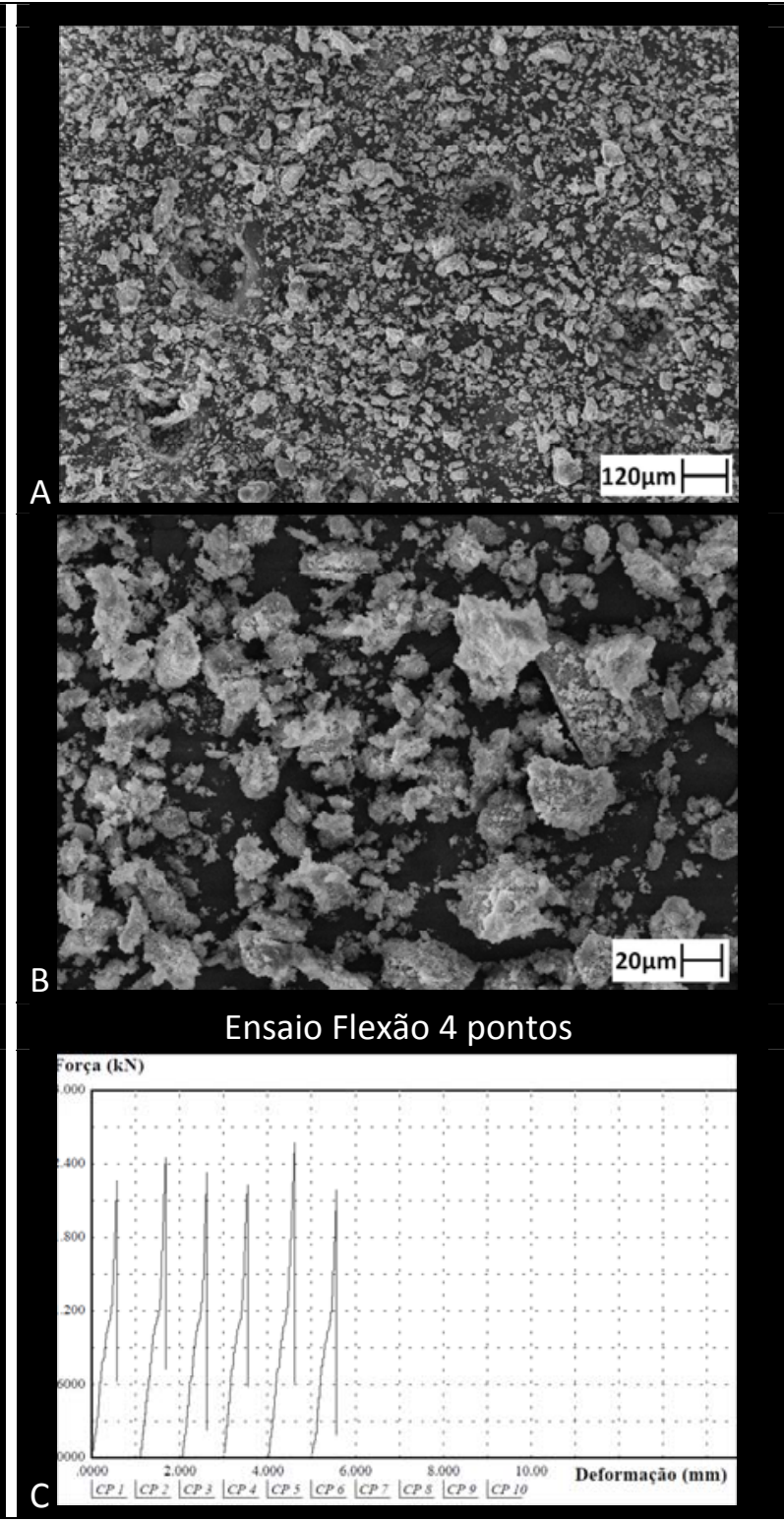

Figura 60 - Usinagem á verde $F=400 \mathrm{~mm} / \mathrm{min}$ e $A=1 \mathrm{~mm}$ 200MPa, em $(A)$ imagem da superfície por MEV, em (B) maior magnificação e em $(C)$ gráfico do ensaio de flexão a quatro pontos após sinterização

Nas Figuras 61 a 64, foram comparadas amostras apenas com tratamento diferentes, a amostra não tratada é com o pó somente prensado e com repouso de 48hs, na amostra tratada, após a prensagem foi mantida em estufa a $100^{\circ} \mathrm{C}$ por $12 \mathrm{hs}$. Entre as imagens item (A), o cavaco da amostra tratada é significativamente menor, o que configura a usinagem como intragranular com poucos danos estruturais a peça usinada. Nas Figuras 61 a 64 (D) demonstra o expressivo ganho de resistência estrutural com o tratamento térmico, peças com maior compactação obtiveram uma resistência mecânica superior. 


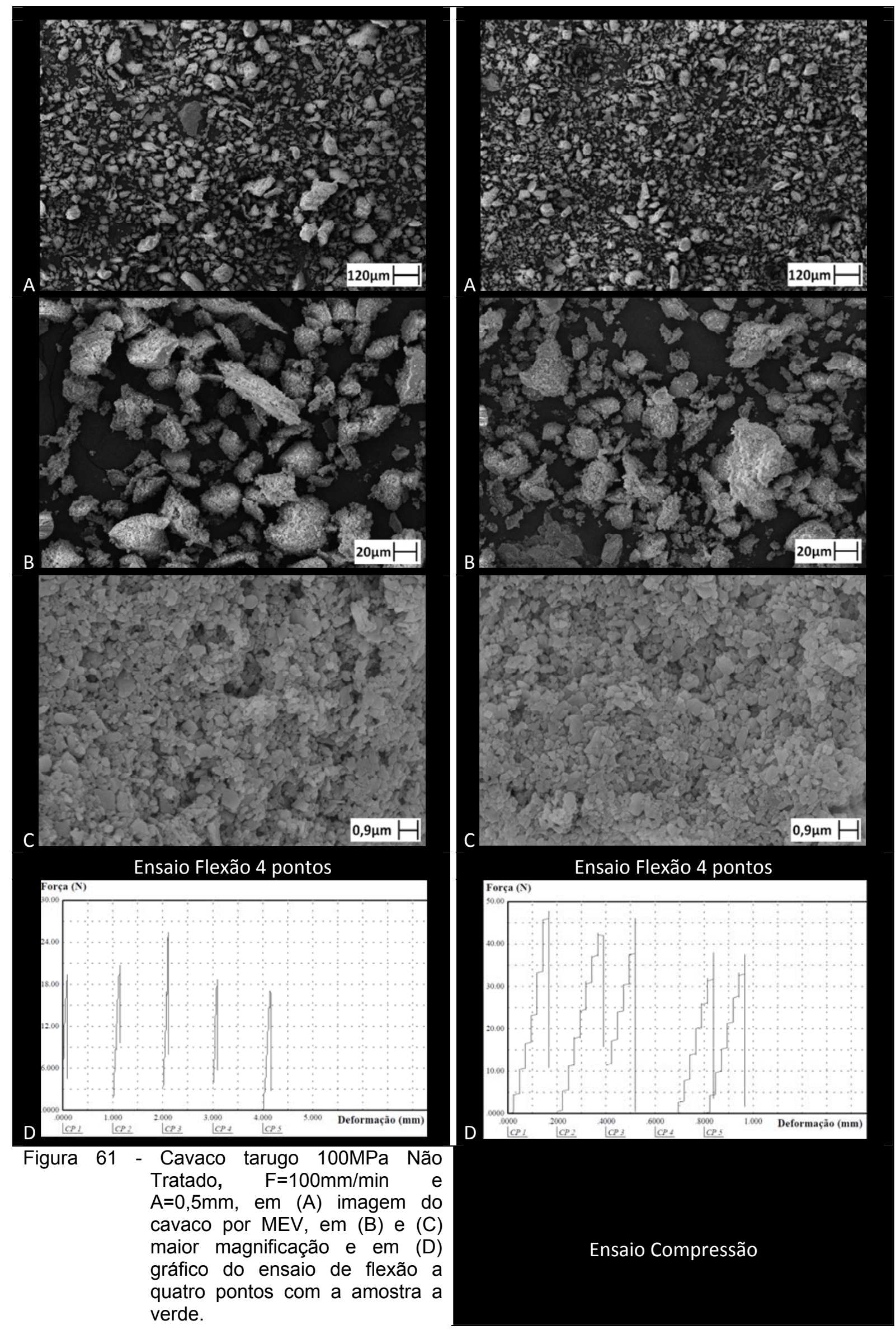




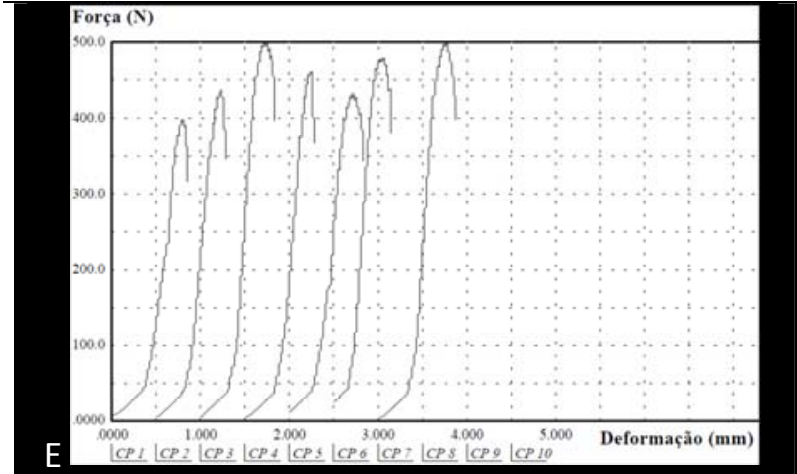

Figura 62 - Cavaco tarugo 100MPa Tratado, $F=100 \mathrm{~mm} / \mathrm{min}$ e $A=0,5 \mathrm{~mm}$, em (A) imagem do cavaco por MEV, em (B) e (C) maior magnificação em (D) gráfico do ensaio de flexão a quatro pontos com a amostra a verde $e$ em (E) ensaio de compressão com a amostra a verde.

Nos ensaios de compressão Figuras 62 e 62 (E) os valores médios dos corpos prensados a 200MPa foram significativamente superiores, sendo compactados com $100 \mathrm{MPa}$ e tratado termicamente obteve $458,7 \mathrm{~N}$ de resistência a compressão e os corpos prensados a $200 \mathrm{MPa}$ tratados termicamente, $608,6 \mathrm{~N}$. 

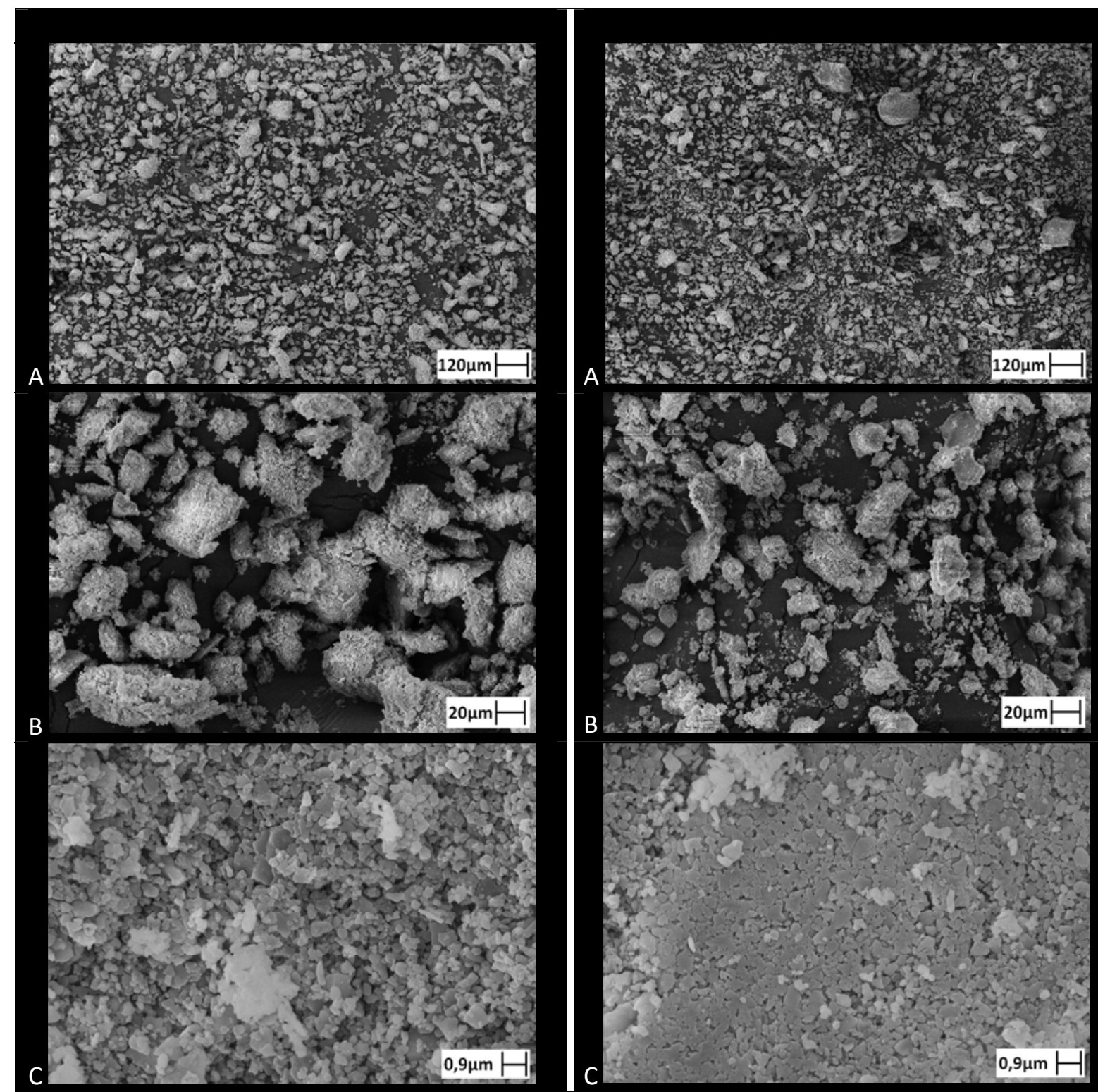
Figura 63 - Cavaco tarugo 200MPa Não Tratado, $\quad F=100 \mathrm{~mm} / \mathrm{min} \quad \mathrm{e}$ $A=0,5 \mathrm{~mm}$, em (A) imagem do cavaco por MEV, em (B) e (C) maior magnificação e em (D) gráfico do ensaio de flexão a quatro pontos com a amostra a verde.

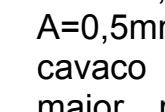

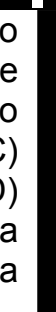$$
\text { (1) }
$$

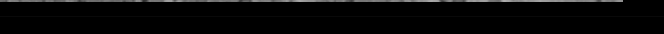




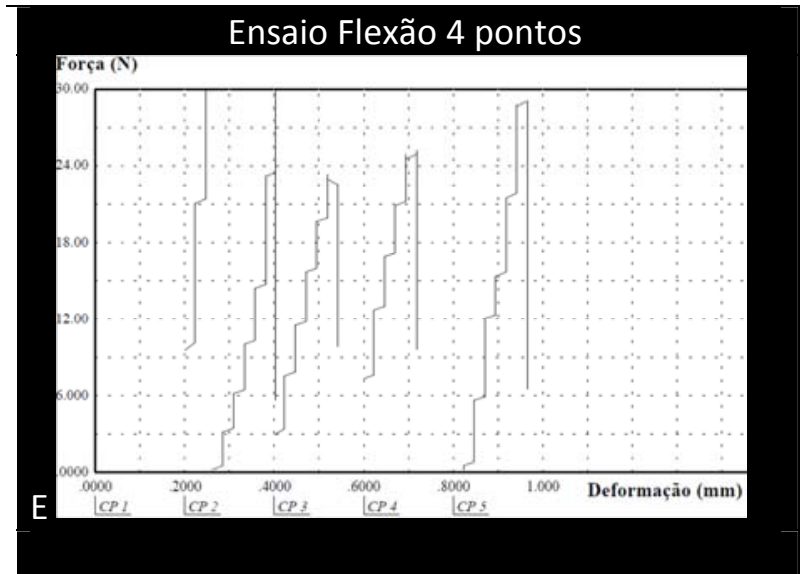

Figura 64 - Cavaco tarugo 200MPa Tratado, $\mathrm{F}=100 \mathrm{~mm} / \mathrm{min}$ e $\mathrm{A}-0,5 \mathrm{~mm}$, , em (A) imagem do cavaco por MEV, em (B) e (C) maior magnificação em (D) gráfico do ensaio de flexão a quatro pontos com a amostra a verde $e$ em e) ensaio de compressão com a amostra a verde.

As Figuras 65 e 66 comparam às superfícies onde ocorreu a ruptura por ensaio de flexão a 4 pontos de amostras sinterizadas, a amostra da Figura 65 com a menor tensão de ruptura e em Figura 66 a maior resistência mecânica, ou seja, os extremos do lote, as setas indicam o inicio da trinca onde são observados vários desvios na propagação da trinca, nas imagens com maior magnificação notou-se o mesmo aspecto devido ao relevo mais acentuado da superfície. 


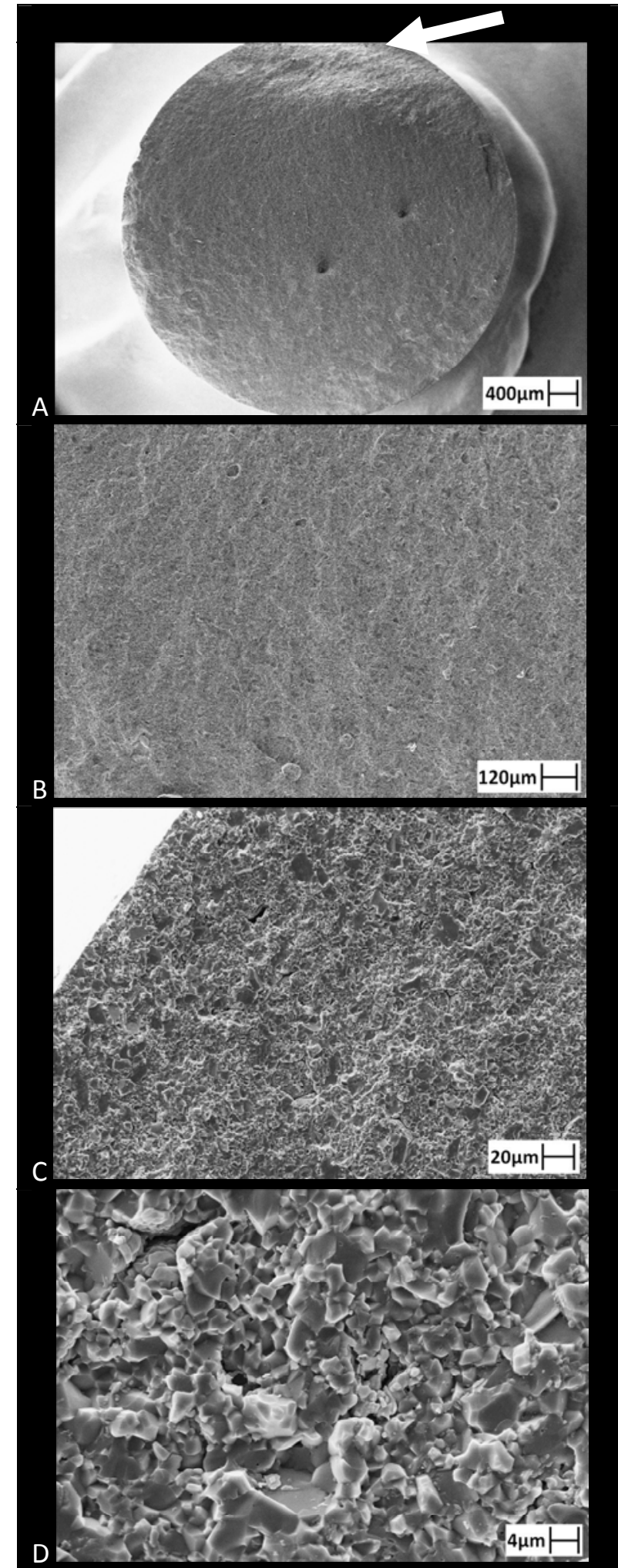

Figura 65 - Tarugo Sinterizado $100 \mathrm{MPa}-$ $183 \mathrm{~kg}$ ruptura, em (A) até (D) maior magnificação.

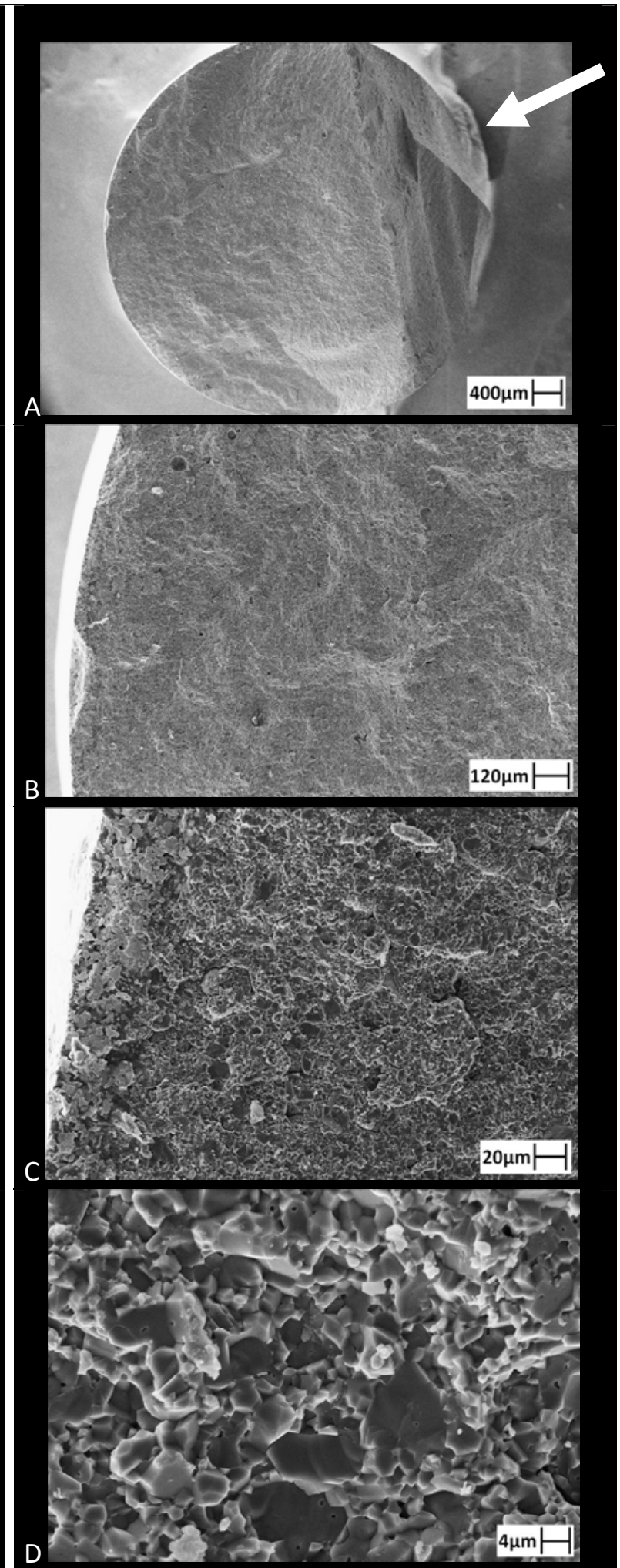

Figura 66 - Tarugo Sinterizado 100MPA - 255kg ruptura, em (A) até (D) maior magnificação. 
A tabela 6 exibe os resultados da média de 5 amostras para cada parâmetro de usinagem, onde se variou a profundidade de corte e velocidade de avanço da ferramenta. A potência consumida foi obtida através da correlação com o torque, onde

Potência $=($ Força $\times$ Distância $) /$ Tempo

$[\mathrm{W}]=[\mathrm{N} \cdot \mathrm{m} / \mathrm{s}]$ no SI

Perímetro $=2 \pi .1$ (metro)

Massa $x$ Aceleração $=$ Força em $[\mathrm{N}]$ Newton, ou [kgf] kilograma-força Força $x$ Distância percorrida= Trabalho ou Energia em [J] Joule, ou [kgf.m] kilograma-forçametro

Trabalho $/$ Tempo $=$ Potência $[\mathrm{J} / \mathrm{s}]$ Joule por segundo ou [W] Watt, ou ainda [HP] Horse Power, ou [cv] cavalo-vapor.

Neste caso, $\mathrm{P}=\mathrm{T} .2 \pi .11400 / 60$

Tabela 6 - Resultados de diferentes parâmetros na usinagem a verde

\begin{tabular}{|c|c|c|c|c|c|c|c|c|c|c|c|c|}
\hline $\begin{array}{l}\text { avanço ff } \\
\text { (mm/min) }\end{array}$ & $\begin{array}{l}\text { profundidade } \\
\text { ap (mm) }\end{array}$ & $\begin{array}{l}\text { Potência (W) } \\
\text { (100MPa) }\end{array}$ & $\begin{array}{c}\text { Potência (W) } \\
\text { (200MPa) }\end{array}$ & $\begin{array}{l}\text { tensão media } \\
\text { (100MPa) }\end{array}$ & \begin{tabular}{|l|} 
desvio padrão \\
tensão \\
(100MPa)
\end{tabular} & $\begin{array}{l}\text { tensão media } \\
\text { (200MPa) }\end{array}$ & $\begin{array}{l}\text { desvio padrão } \\
\text { tensão } \\
\text { (200MPa) }\end{array}$ & $\left.\begin{array}{l|l}\text { taxa de } & t \\
\text { remoção } \\
(\mathrm{mm} 3 / \mathrm{min})\end{array}\right)$ & $\begin{array}{l}\text { torque } \\
\text { (100MPa) } \\
\text { (N.m) }\end{array}$ & $\begin{array}{l}\text { desvio } \\
\text { torque } \\
\text { (100MPa) }\end{array}$ & $\begin{array}{l}\text { torque } \\
\text { (200MPa) } \\
\text { (N.m) }\end{array}$ & $\begin{array}{l}\text { desvio } \\
\text { torque } \\
\text { (200MPa) }\end{array}$ \\
\hline 100 & 0,5 & 76,1 & & 155,40 & 24,92 & & & 1256,64 & 0,0638 & 0,01 & & \\
\hline 100 & 0,5 & 101,1 & 386,4 & 325,51 & 35,69 & 398,67 & 86,60 & 1256,64 & 0,0847 & 0,00 & 0,3237 & 0,04 \\
\hline 200 & 0,5 & 76,1 & & 246,15 & 17,53 & & & 2513,27 & 0,0157 & 0,00 & & \\
\hline 300 & 0,5 & 225,9 & & 294,35 & 20,43 & & & 3769,91 & 0,1892 & 0,02 & & \\
\hline 400 & 0,5 & 712,1 & & 246,73 & 42,75 & & & 5026,55 & 0,5965 & 0,06 & & \\
\hline Média & 0,50 & & & 278,18 & 29,10 & & & & & & & \\
\hline 100 & 1 & 278 & 409 & 246,73 & 24,99 & 331,07 & 21,96 & 2513,27 & 0,2331 & 0,03 & 0,3423 & 0,06 \\
\hline 200 & 1 & 656 & 506 & 282,33 & 20,32 & 293,38 & 41,45 & 5026,55 & 0,5492 & 0,03 & 0,4236 & 0,03 \\
\hline 300 & 1 & 892 & 1286 & 270,52 & 14,08 & 319,27 & 50,57 & 7539,82 & 0,7472 & 0,05 & 1,0772 & 0,03 \\
\hline 400 & 1 & 821 & 1657 & 281,44 & 56,77 & 319,62 & 19,14 & 10053,09 & 0,6876 & 0,10 & 1,3880 & 0,01 \\
\hline Média & 1 & & & 270,25 & 29,04 & 315,83 & 33,28 & & & & & \\
\hline
\end{tabular}

As Figuras 67 e 68 mostram a variação da resistência mecânica das amostras sinterizadas em função do aumento da taxa de remoção composto pelas profundidades de corte de 0,5 e 1,0mm. È observado que com o aumento da velocidade de corte há uma melhoria nas propriedades mecânicas relacionadas ao acabamento superficial, baseados nas imagens mostradas pelas Figuras 49 a $56(\mathrm{~A})$, porém foi encontrado um limite de velocidade de avanço igual $400 \mathrm{~mm} / \mathrm{min}$ para os corpos de prova pensados a $100 \mathrm{MPa}$ observado pelo aumento das barras de erros, sendo que, ultrapassado este limite foi verificado uma região instável onde ocorre a ruptura catastrófica dos corpos durante o percurso do rebolo em posições indefinidas, isto devido aos esforços de corte que ultrapassaram a resistência mecânica da peça, levando à ruptura. Não pôde se verificar a introdução progressiva de defeitos superficiais como o observado por Fortulan (2011) na usinagem de porcelana, o diferencial está no cabeçote de usinagem que neste trabalho foi com mancais aerostáticos onde os ruídos e vibrações foram extremamente diminuídos e devido a reserva de potência do cabeçote de $2400 \mathrm{~W}$ contra $500 \mathrm{~W}$ utilizado naquele trabalho, outra diferença foi no uso do spray dry e do tamanho médio de partícula de $0,4 \mu \mathrm{m}$ 
que facilitou a usinagem em regime intragranular, naquele trabalho foi ensaiado porcelana elétrica em condições industriais de tamanho de partícula e processamento.

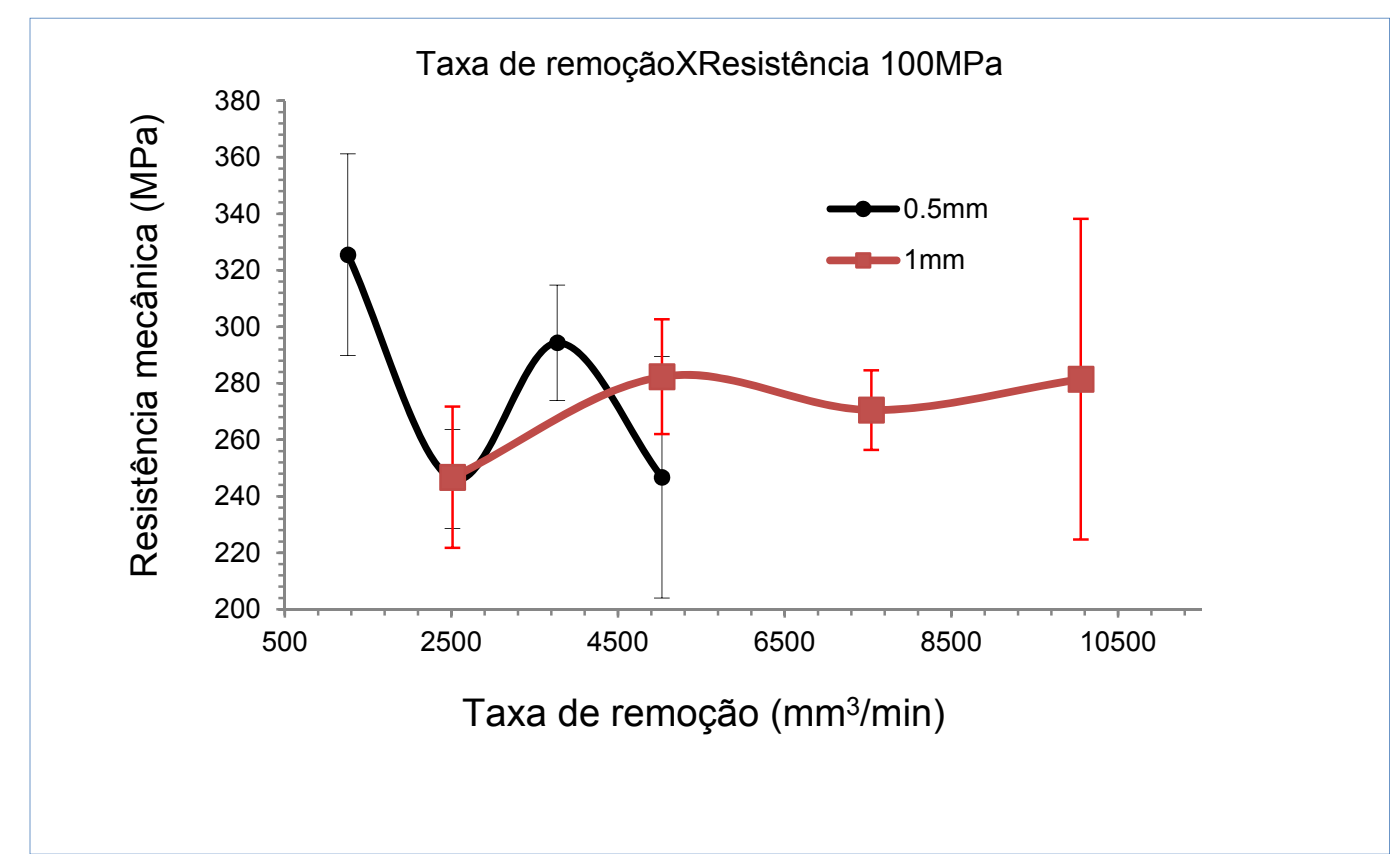

Figura 67 - Resistência mecânica das amostras sinterizadas em função da taxa de remoção.

Já nas peças prensadas a 200MPa, não foi verificado aumento da barra de erros, Figura 68. Condições mais agressivas não foram testadas por limitações na potencia do motor de avanço.

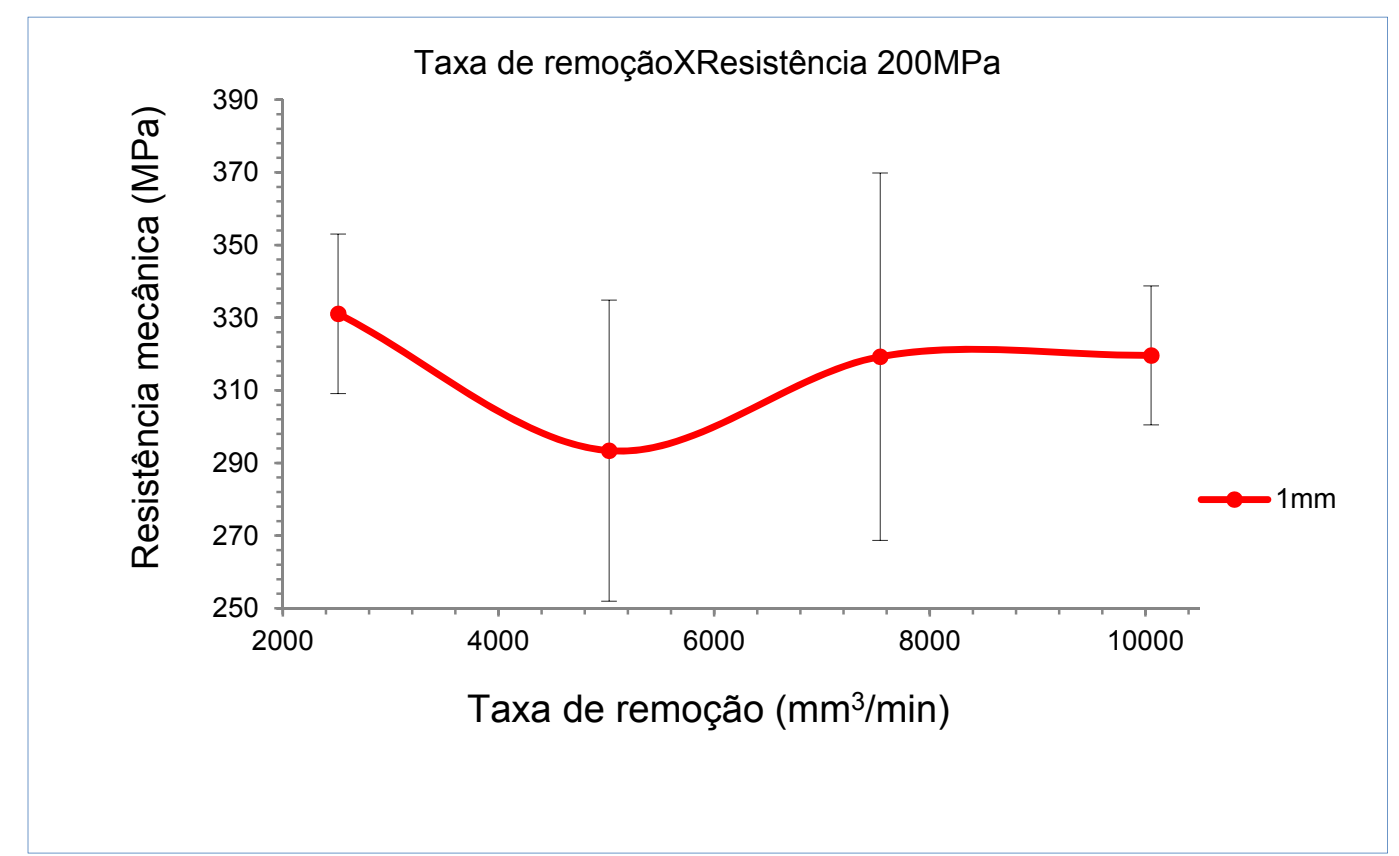

Figura 68 - Resistência mecânica em função da taxa de remoção, amostras comprimidas a 200MPa com profundidade de corte de $1 \mathrm{~mm}$. 
As Figuras 69 a 70 mostram a potência consumida em Watts pela usinagem, notase um aumento do torque com o aumento do avanço e também com a profundidade de corte ou certa similaridade com a taxa de remoção independe das condições de composição (avanço e profundidade). A queda na potencia consumida após a taxa de remoção de 8000 ( $\mathrm{mm} 3 / \mathrm{min}$ ) nas amostras de $100 \mathrm{MPa}$, se deve ao limite de resistência da peça a verde, onde passa a ocorrer fraturas. Já na figura 70 , as peças de 200MPa apresentam uma resistência muito superior, não acarretando fratura devido a usinagem, nas condições do experimento.

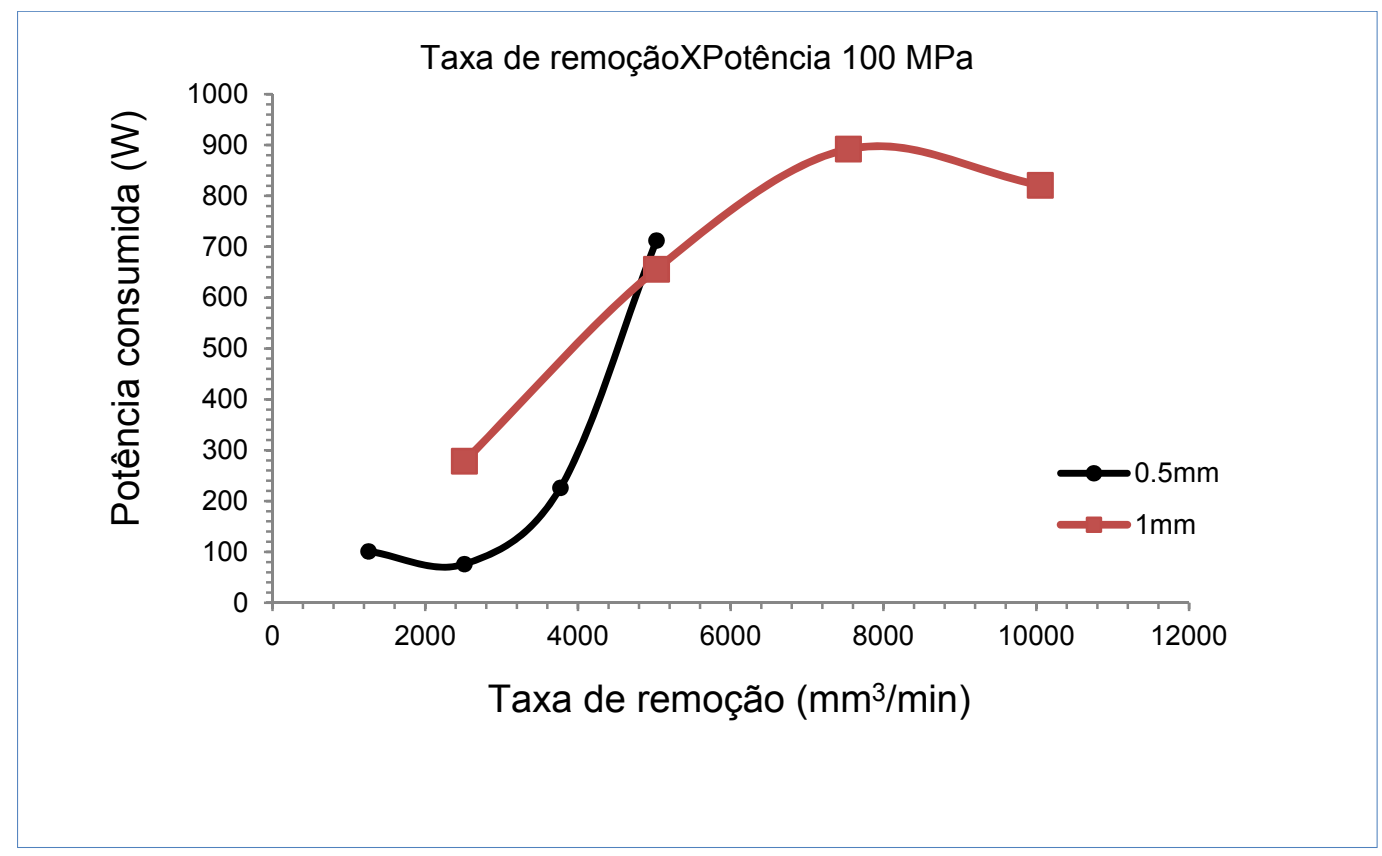

Figura 69 - Potência de corte consumida em função da taxa de remoção 100MPa.

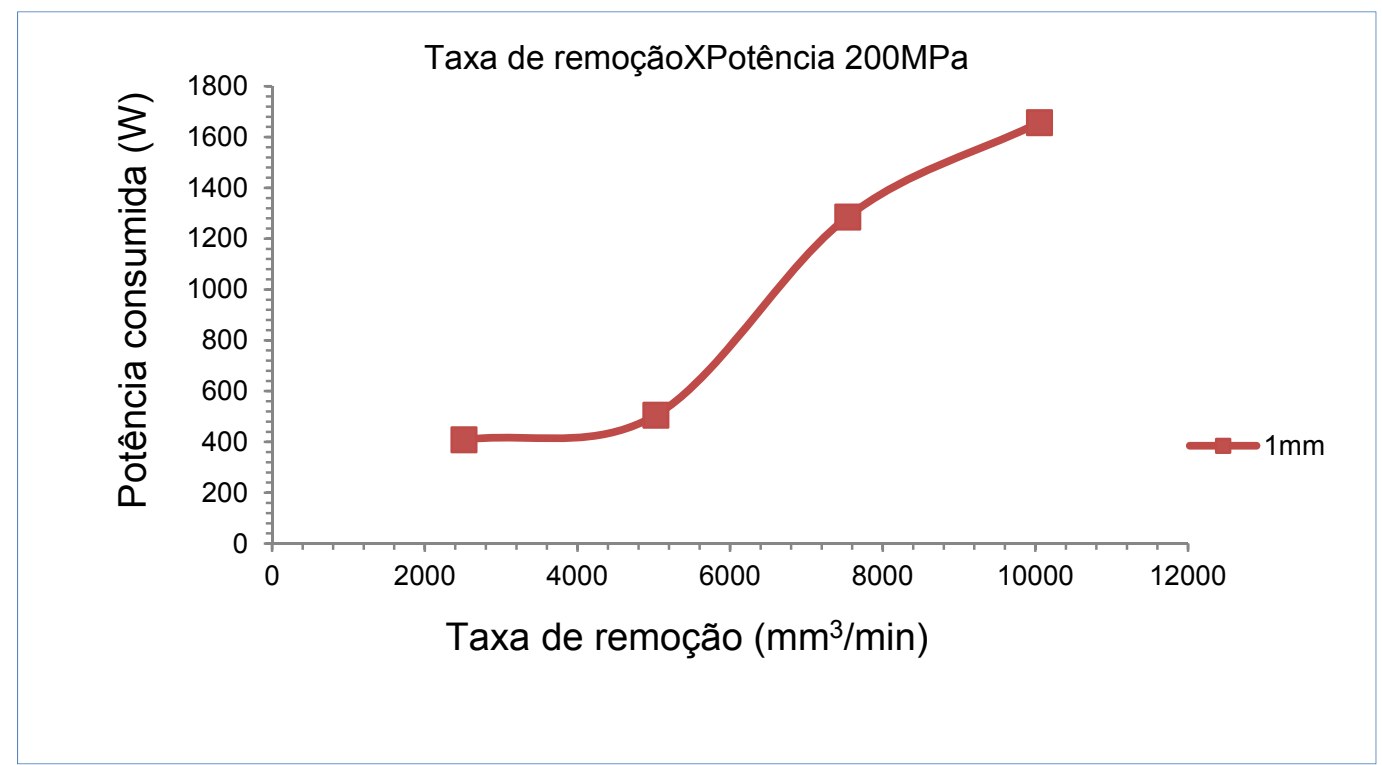

Figura 70 - Potência de corte consumida em função da taxa de remoção 200MPa. 
As Figuras 71 a 72 representa o gráfico de Avanço X resistência Mecânica para diferentes avanços e profundidade de corte, evidenciando uma ligeira queda na resistência das peças a 100MPa com o aumento do avanço da ferramenta, sendo que próximo de $400 \mathrm{~mm} / \mathrm{min}$ esta no limite de ruptura do corpo de provas, observado o desvio padrão alto neste ponto. Nas peças comprimidas a 200MPa Figura 72, foi observado outro comportamento, notou-se pouca perda de resistência com o aumento do avanço da ferramenta, neste caso em $400 \mathrm{~mm} / \mathrm{min}$ constatou-se que esta distante do torque necessário para ruptura.

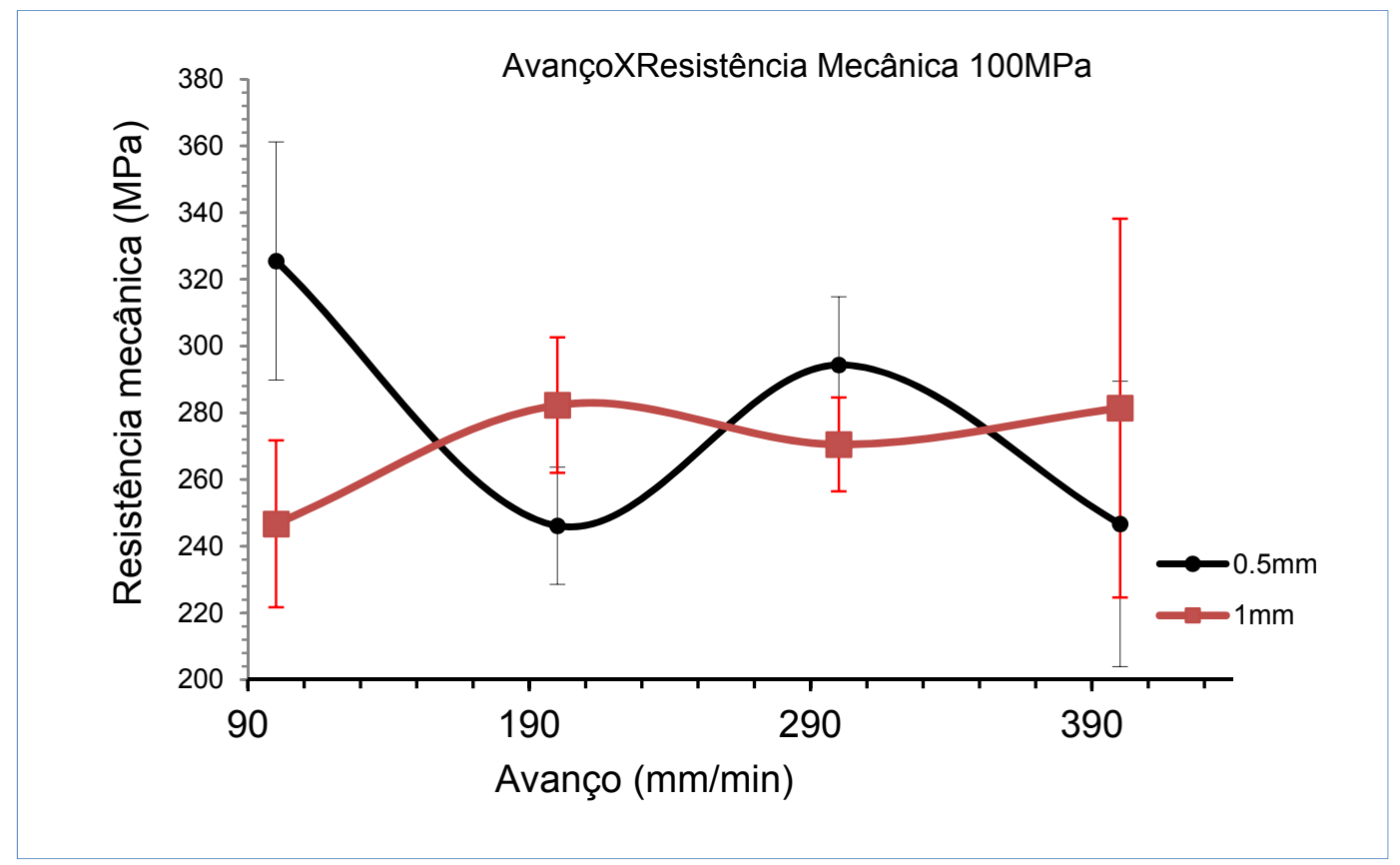

Figura 71 - Gráfico Avanço X Resistencia Mecânica para corpos de prova prensados a 100MPa.

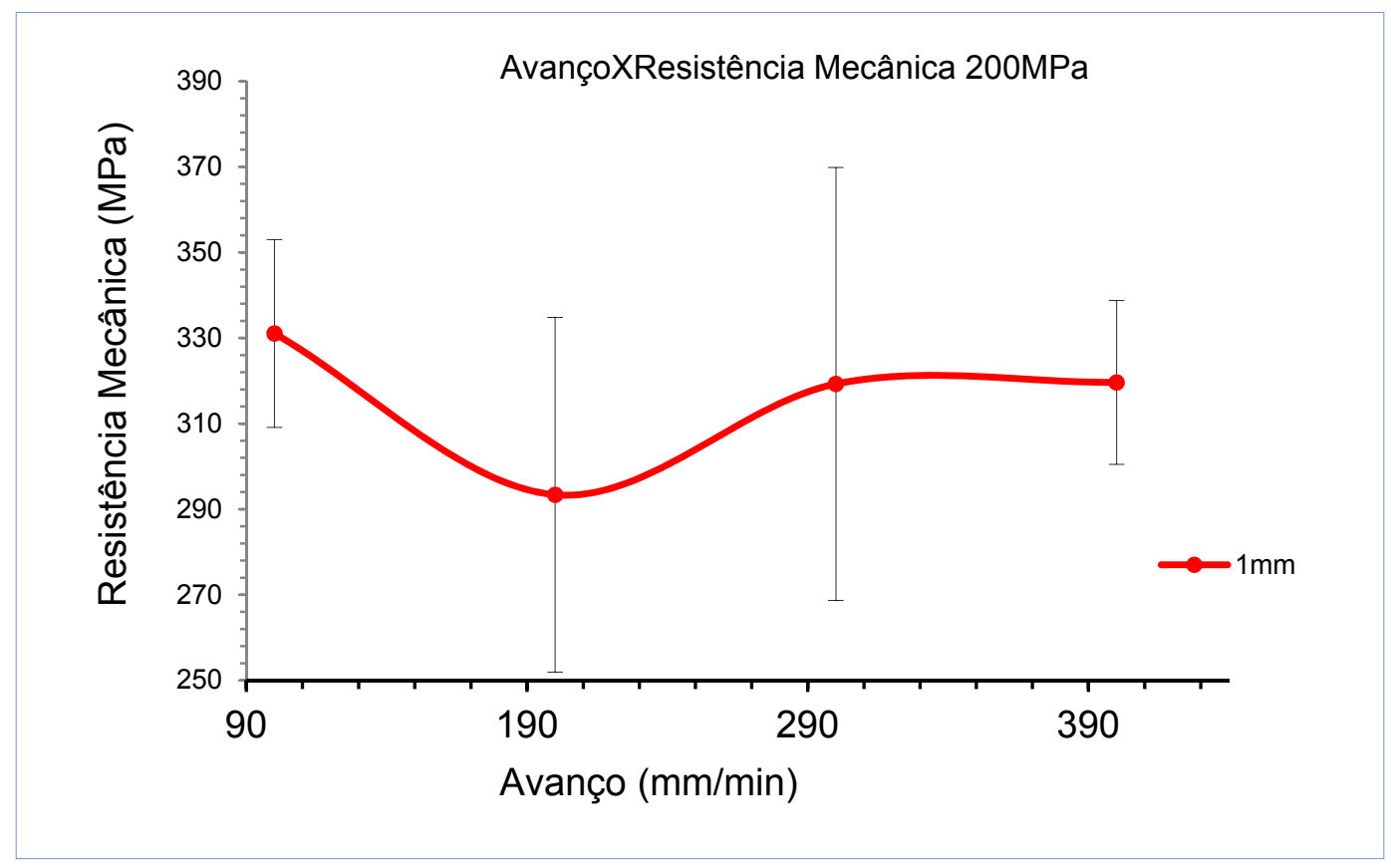

Figura 72 - Gráfico Avanço X Resistência Mecânica para corpos de prova prensados a 200MPa. 
Nas Figuras 73 a 76, Avanço X Torque e Taxa de remoção X Torque, observou-se que para o corpo de provas de 100MPa e com profundidade de $1 \mathrm{~mm}$, chegou ao seu limite de resistência mecânica após o avanço de $300 \mathrm{~mm} / \mathrm{min}$, diminuindo o torque até a ruptura, observou-se também que o ensaio com $0,5 \mathrm{~mm}$ de profundidade a $400 \mathrm{~mm} / \mathrm{min}$ está próximo ao limite de torque máximo atingido. Na Figura 77 , os corpos comprimidos a $200 \mathrm{MPa}$ apresentam uma resistência mecânica superior, onde mesmo na condição mais severa não se notou a ruptura nos ensaios.

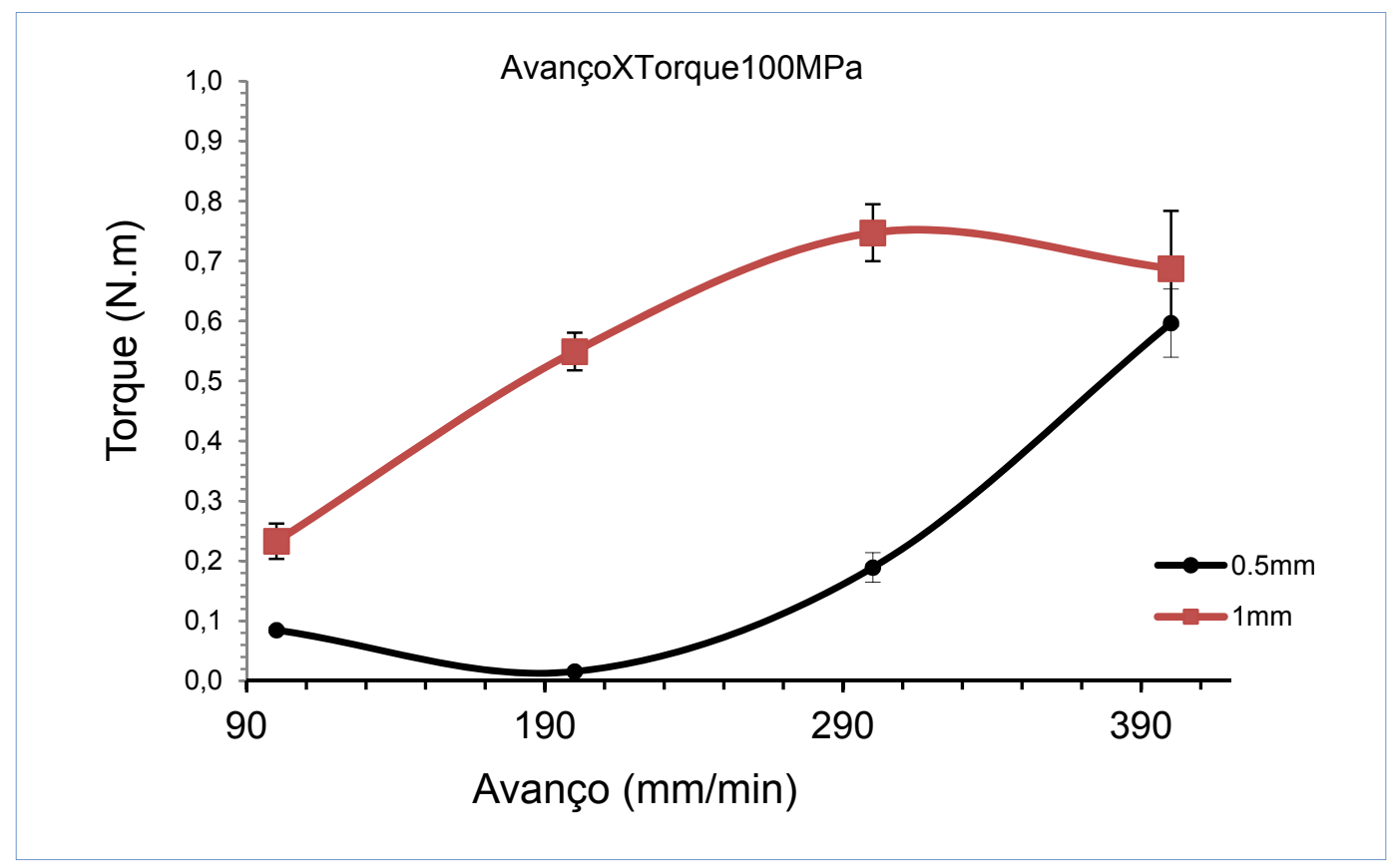

Figura 73 - Gráfico Avanço X Torque para corpos de prova prensados a 100MPa.

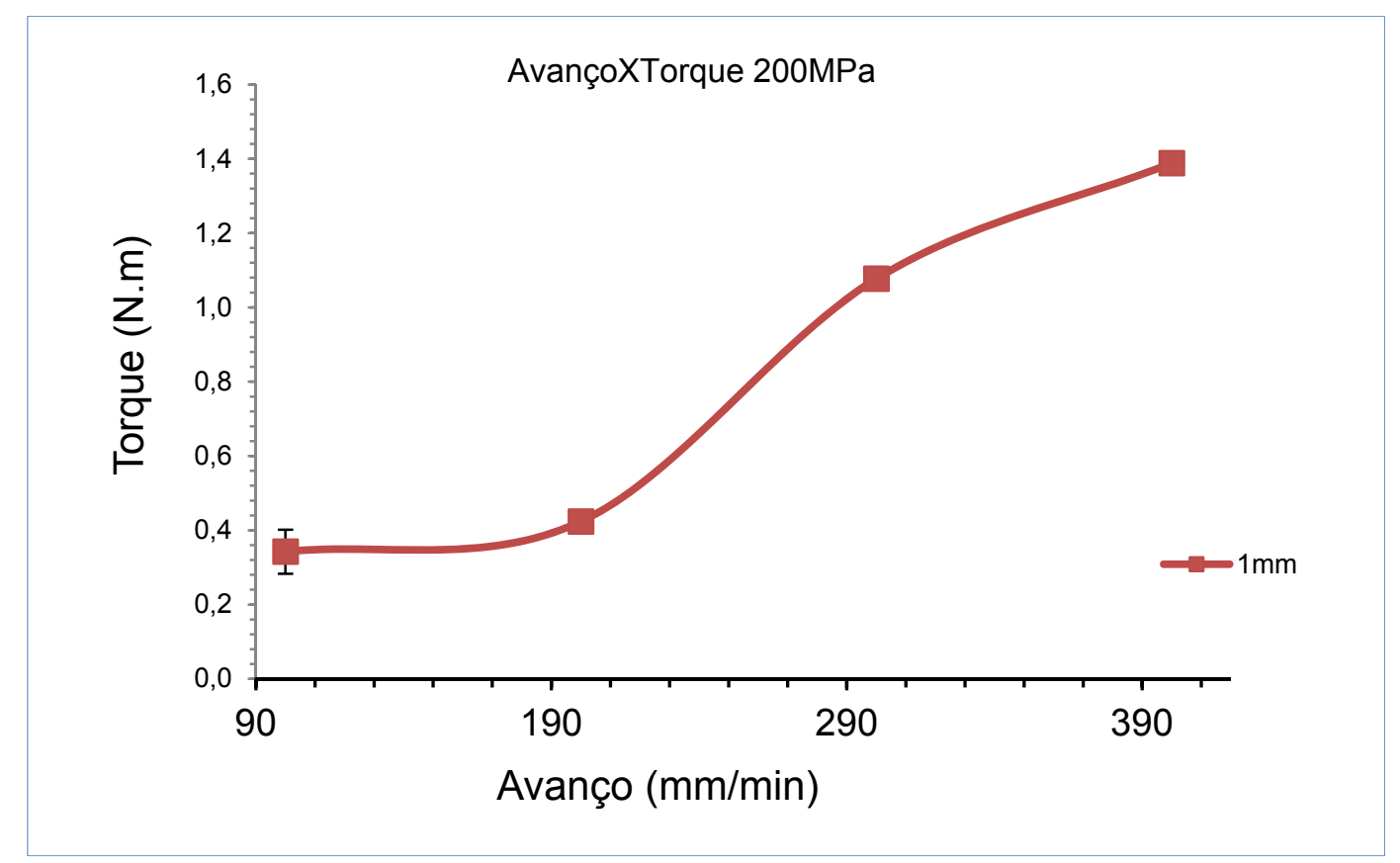

Figura 74 - Gráfico Avanço X Torque para corpos de prova prensados a 200MPa. 


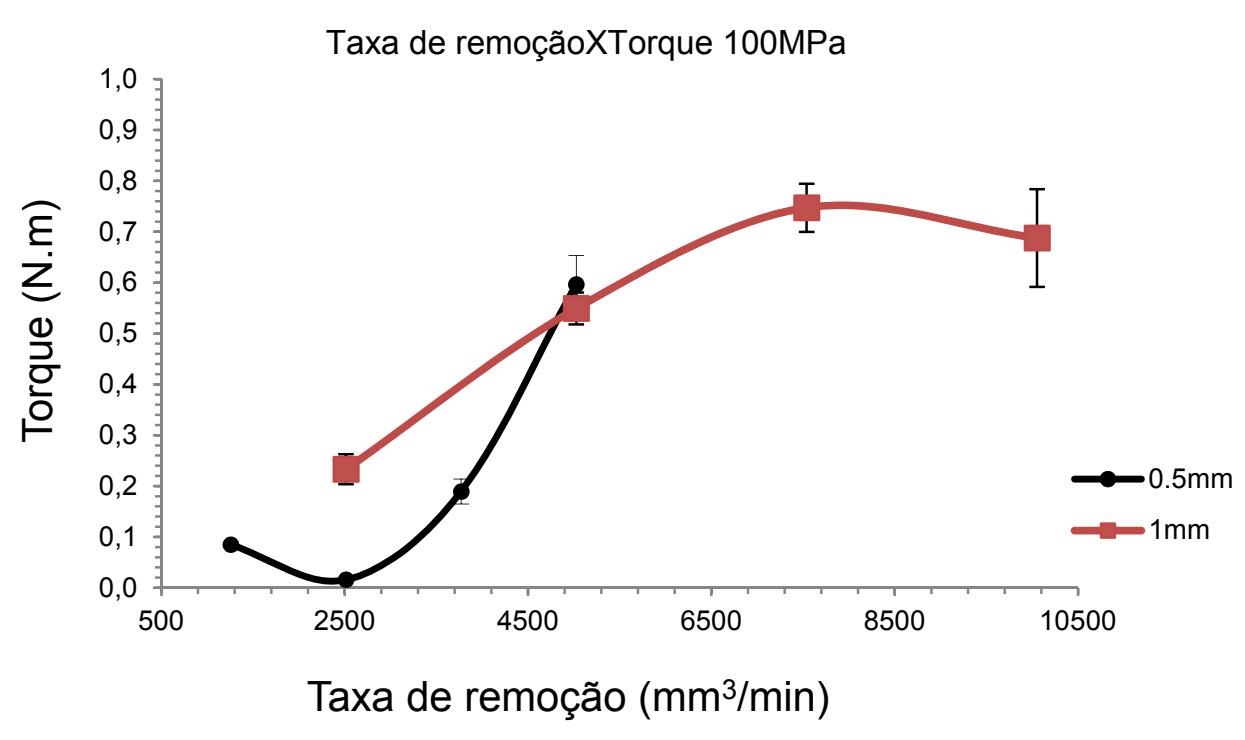

Figura 75 - Gráfico Taxa de remoção X Torque para corpos de prova prensados a 100MPa.

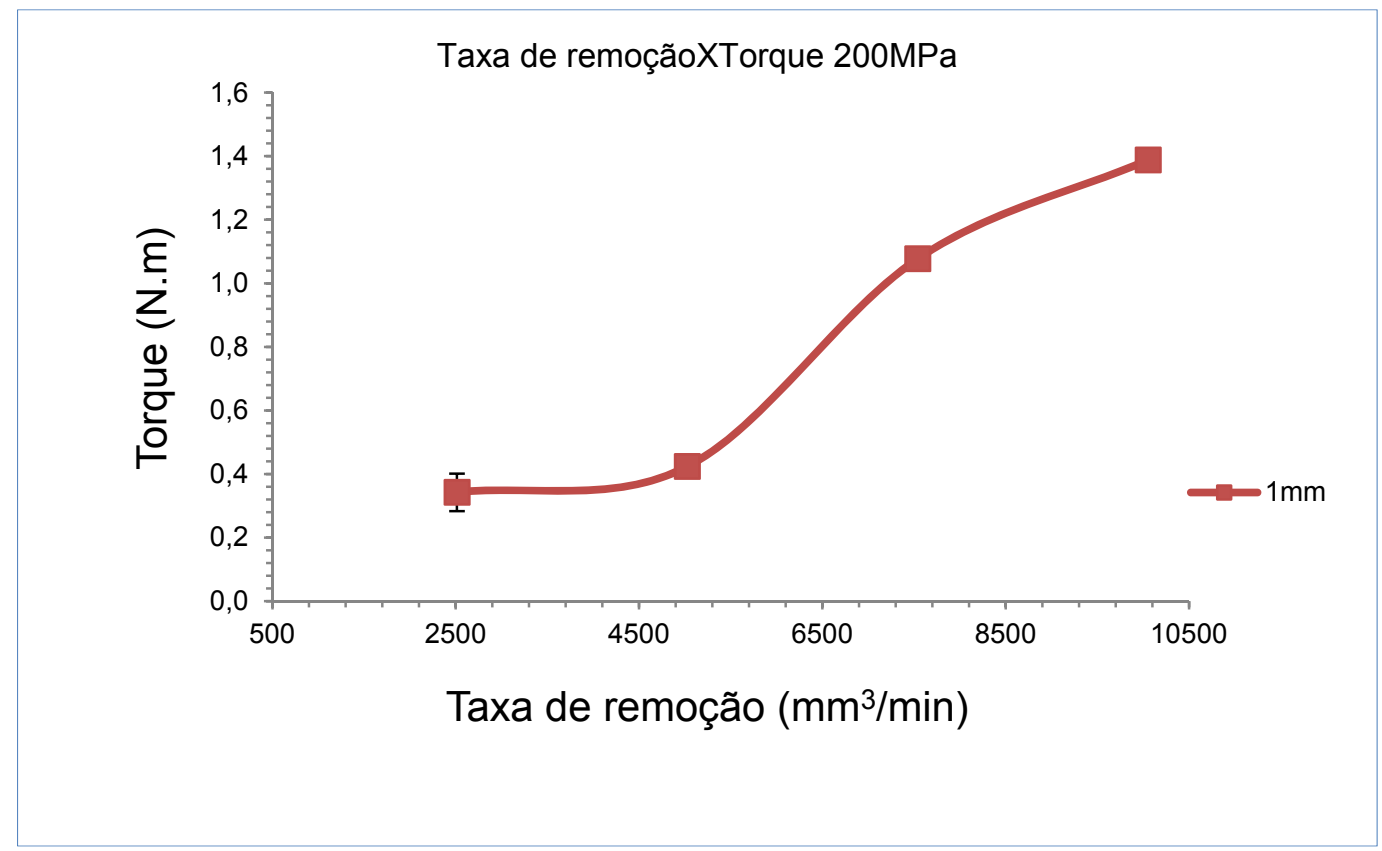

Figura 76 - Gráfico Taxa de remoção X Torque para corpos de prova prensados a 200MPa.

\subsection{Análise vibratória do equipamento}

Nos ensaios em diferentes parâmetros, foi notado uma descontinuidade na resistência mecânica das peças usinadas com avanço de $200 \mathrm{~mm} / \mathrm{min}$, o que indicou alguma possível interferência causada pelo próprio equipamento na usinagem, para tanto foi medida a vibração no porta ferramentas da máquina em todas as condições diferentes de usinagem na busca de uma possível condição de ressonância. 
O acelerômetro utilizado foi o PCB PIEZOTRONICS, modelo 353B03 Figura 77 (B), com sensitividade: $10,06 \mathrm{mV} / \mathrm{g}$ e o condicionador de sinal utilizado foi o PCB PIEZOTRONICS, modelo: 482B11 Figura 77 (A)com ganho: 1x com saída analógica cedido pela FEB-UNESP.
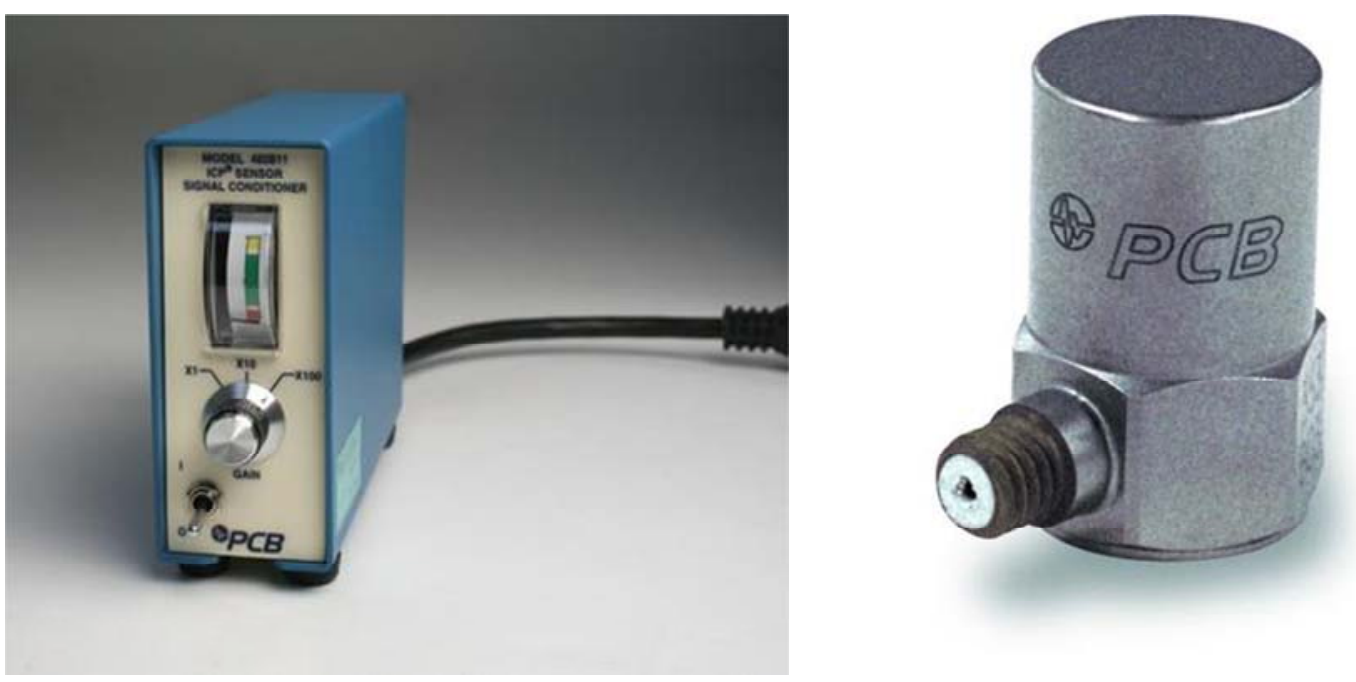

A

B

Figura 77 - Em a) condicionador de sinal PCB PIEZOTRONICS, modelo: $482 \mathrm{~B} 11$ e em b) PCB acelerômetro PIEZOTRONICS, modelo 353B03

Os resultados dos ensaios de vibração determinam se existe uma ou mais condições em que o equipamento pode entrar em ressonância ou gerar uma vibração excessiva. Na Figura 78, foram identificadas as vibrações naturais da maquina na condição de repouso com todos os motores ligados.

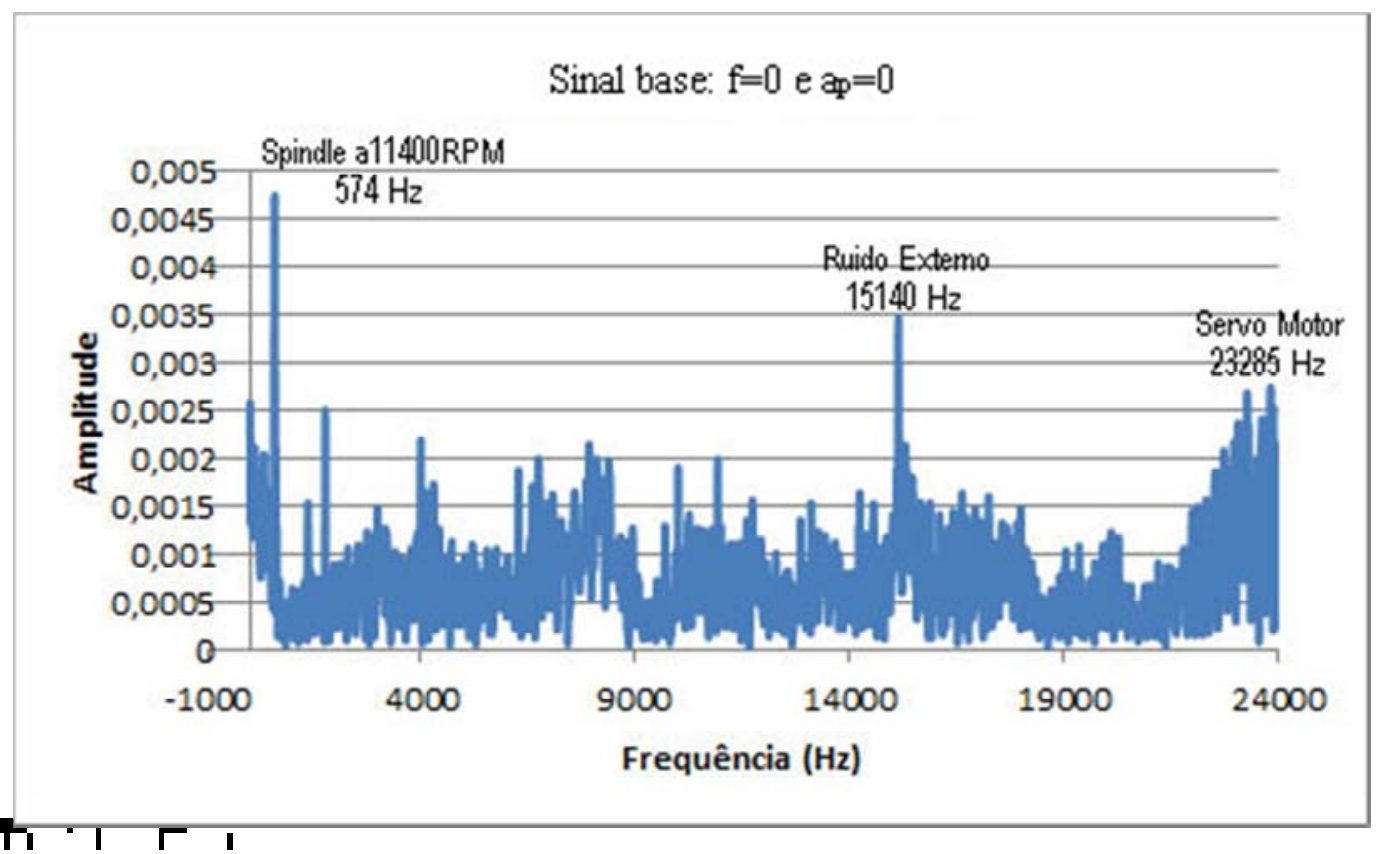

Figura 78 - Sinal base, equipamento ligado sem exercer usinagem. 
Os gráficos das Figuras 79 e 80 , se referem as diferentes condições de corte aplicadas aos Blanks compactados a $100 \mathrm{MPa}$ com profundidade de corte de $0,5 \mathrm{~mm}$ na Figura 79, e profundidade de corte de $1 \mathrm{~mm}$ na Figura 80.
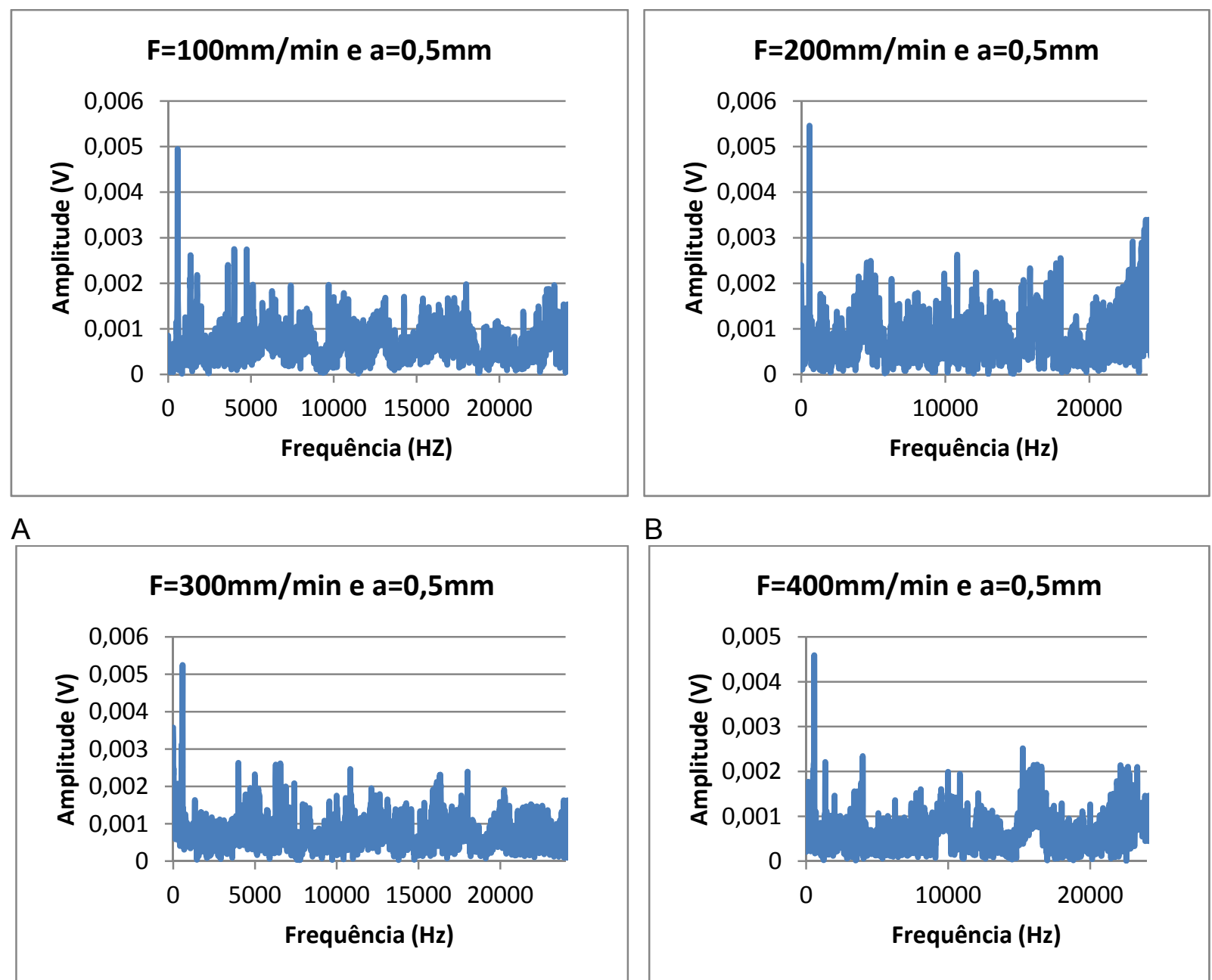

B

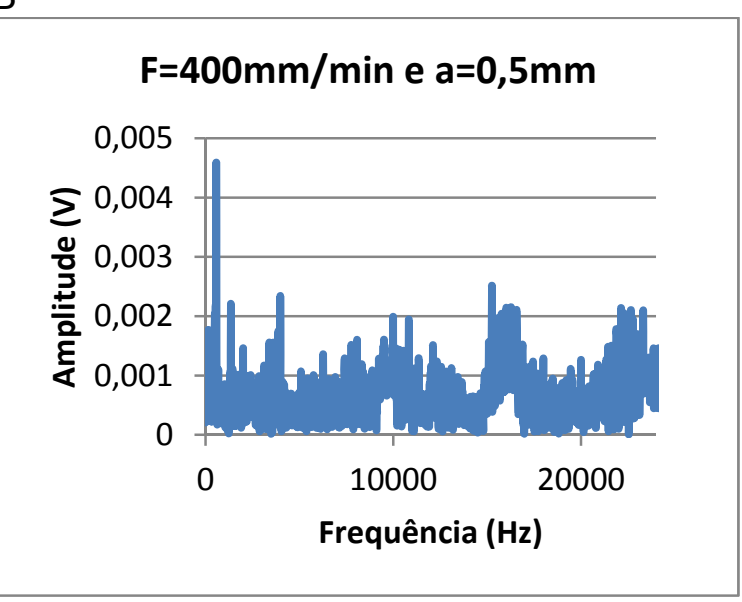

C

\section{$\mathrm{D}$}

Figura 79 - Análise vibratória para usinagem a verde com profundidade de corte fixa em $0.5 \mathrm{~mm}$ e em (A) avanço de $100 \mathrm{~mm} / \mathrm{min}$, em (B) $200 \mathrm{~mm} / \mathrm{min}$, em (C) $300 \mathrm{~mm} / \mathrm{min}$ e em (D) $400 \mathrm{~mm} / \mathrm{min}$. 

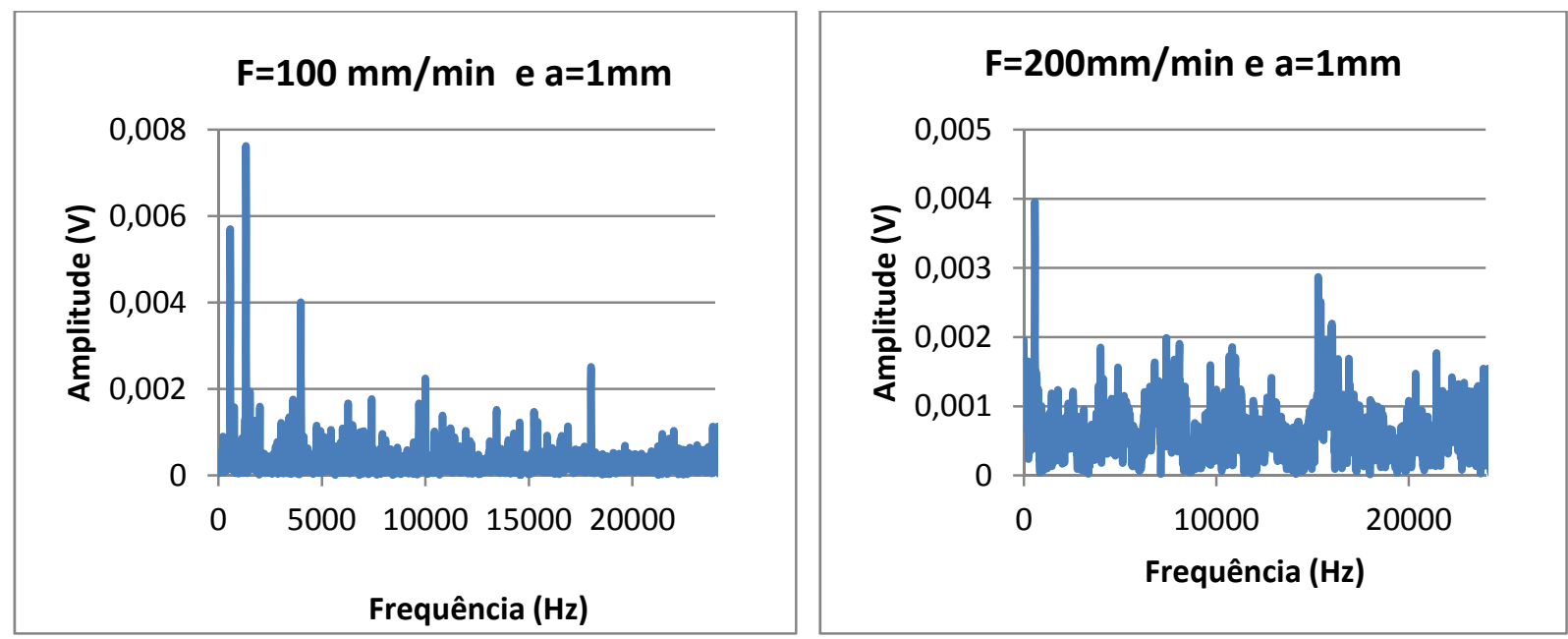

A

B
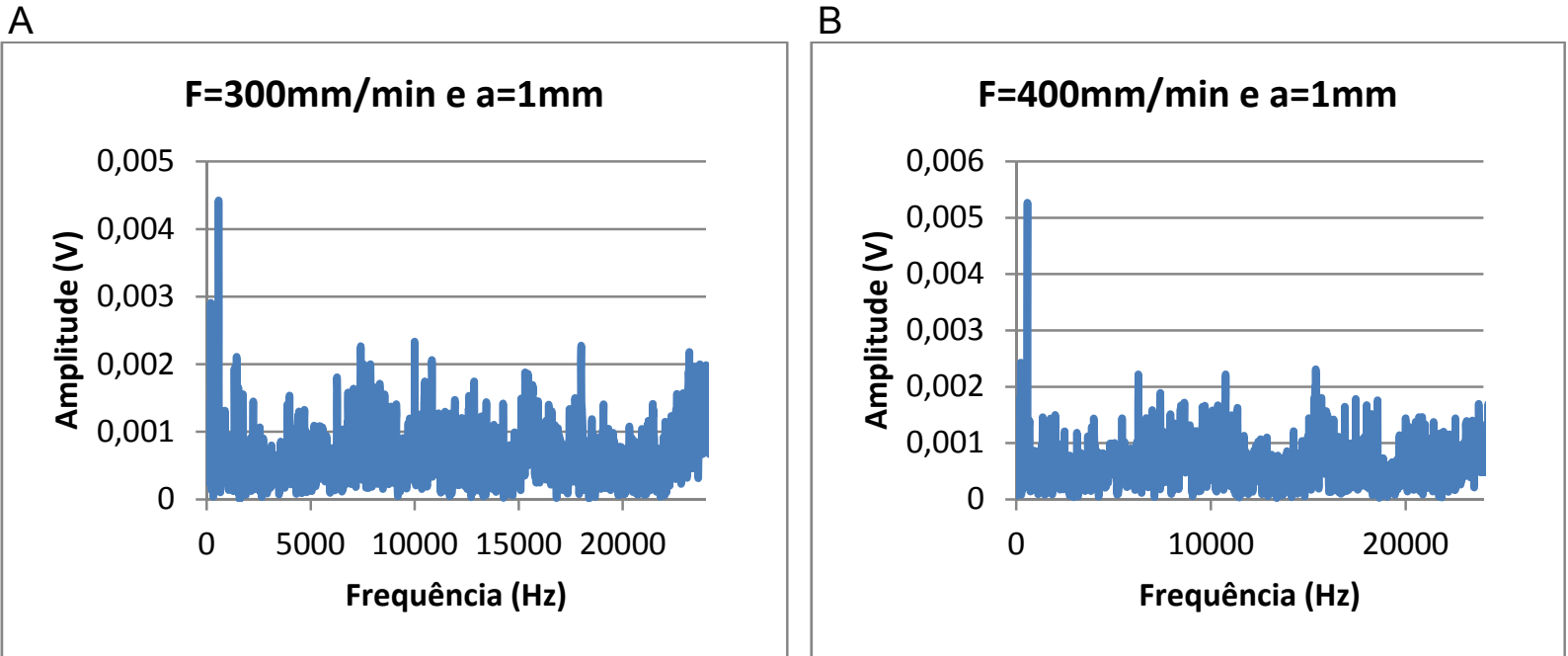

C

$D$

Figura 80 - Análise vibratória para usinagem a verde com profundidade de corte fixa em $1 \mathrm{~mm}$ e em (A) avanço de $100 \mathrm{~mm} / \mathrm{min}$, em (B) $200 \mathrm{~mm} / \mathrm{min}$, em (C) $300 \mathrm{~mm} / \mathrm{min}$ e em (D) $400 \mathrm{~mm} / \mathrm{min}$.

É observado que para avanços de 100 e 200mm/min Figuras 79 e 80, a amplitude média está em torno de $0,75 \mathrm{mV}$ e avanços de $300 \mathrm{~mm} / \mathrm{min}$ e $400 \mathrm{~mm} / \mathrm{min}$ amplitude média em torno de $0,8 \mathrm{mV}$. Quando em corte houve variação de $0,85 \mathrm{mV}$ para $0,9 \mathrm{mV}$, nas faixas de avanços respectivas. $\mathrm{Na}$ taxa específica de $200 \mathrm{~mm} / \mathrm{min}$ não se encontrou nenhum evento vibratório significativo que explicasse a queda da resistência mecânica. 


\subsection{Estudo de Caso}

Foram obtidos os pinos dentários com dimensão e forma planejadas. Os pinos têm estrutura densa com superfície heterogênea, sendo que a região com gradiente de porosidade foi planejada para estar em contato com o tecido ósseo.

Na Figura 81 podem-se observar as principais etapas da usinagem do implante dental.
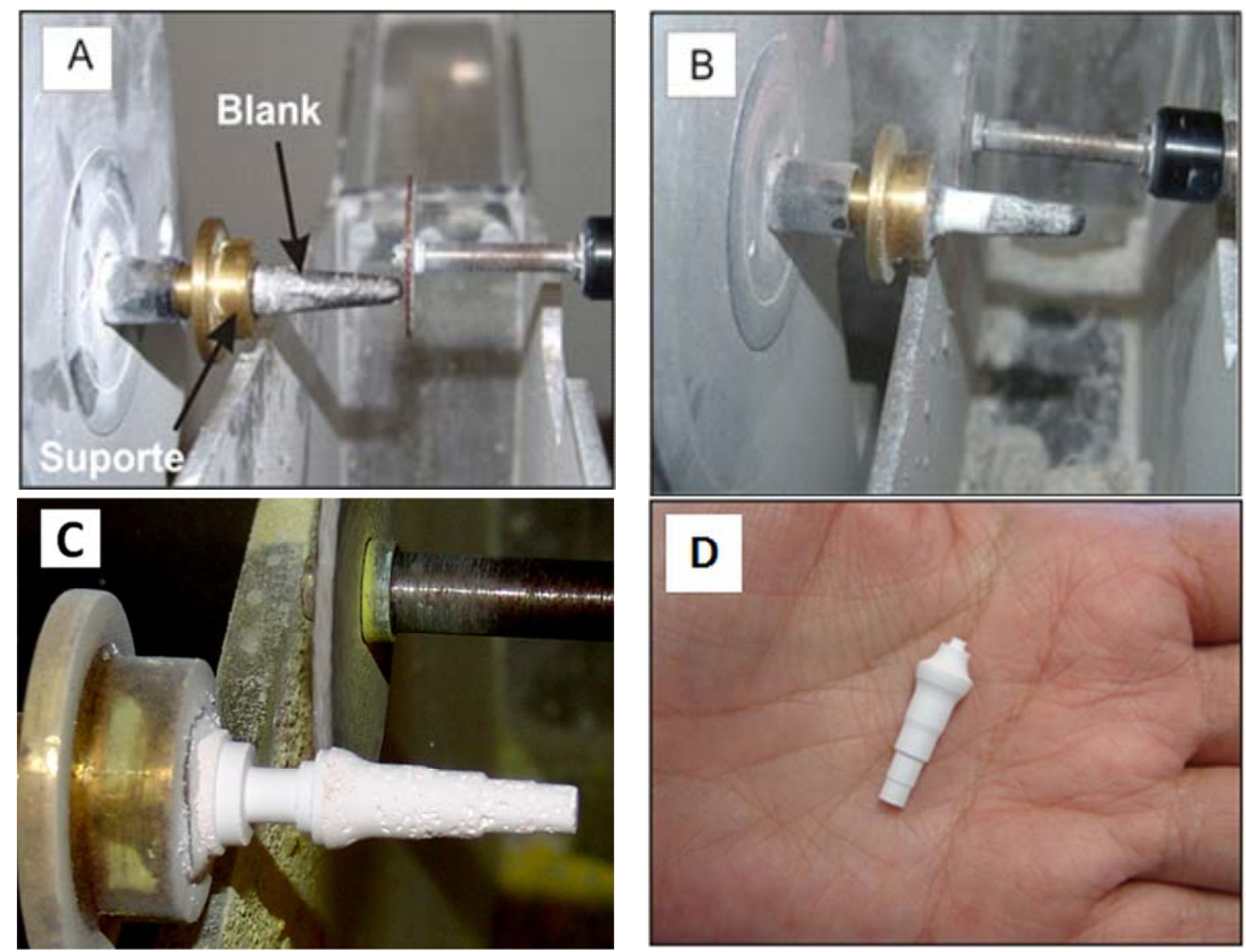

Figura 81 - Usinagem de Blank no formato de pino de dente. (A) Blank fixado no suporte. (B) Blank durante usinagem. (C) Usinagem em fase final de acabamento. (D) Pino usinado. 
Após a usinagem, o implante dental foi sinterizado a $1600^{\circ} \mathrm{C}$ com patamar de 2 horas para obter o produto final (Figura 82). O produto, após a sinterização apresentou as características idealizadas no projeto conceitual do implante dentário.

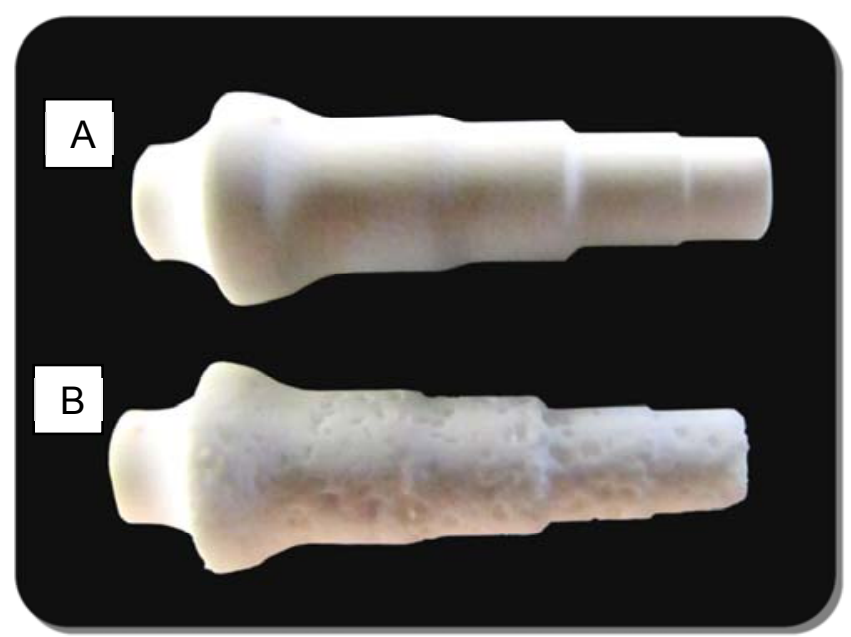

Figura 82 - Pino dentário sinterizado em (A) denso, (B) com gradiente funcional de porosidade. 


\section{CONCLUSÕES}

A leitura da força de corte, representada pela medida do torque efetivo da usinagem mostrou a ocorrência de uma região de instabilidade próxima ao limite de ruptura do corpo de prova. Este trabalho conclui que a usinagem idealizada, conjugada com a manufatura adequada minimiza esta região instável a uma estreita faixa e não progressiva como era pressuposto.

Usinagem idealizada para cerâmica à verde é entendida por aquela que reúne: operação de muito baixo ruído; rebolo ativo; dressagem efetiva; rigidez; controle de movimentações (lineares, interpolada e rotativas) uniformes.

O emprego de um cabeçote com mancais aerostáticos de alta potência garantiu baixo ruído e estabilidade à alta rotação. Nas amostras prensadas a 100MPa pode-se identificar esta faixa instável, a taxa de remoção excedeu a resistência mecânica o que ocasionou em ruptura das amostras; Nas amostras prensadas à 200MPa (tratadas termicamente) esta condição não foi observada pois atingiu o limite de velocidade do banco de ensaio.

Ficou evidenciada a necessidade de tratamento térmico das peças pós-prensagem, pois as amostras prensadas a $100 \mathrm{MPa}$, tratadas termicamente, usinadas $(f=100 \mathrm{~mm} / \mathrm{min}$ e $a_{p}=1 \mathrm{~mm}$ ) e sinterizadas alcançaram tensão de ruptura flexão a quatro pontos média de $\sigma_{\mathrm{RT}}=$ $325,51 \mathrm{MPa}$, enquanto as peças não tratadas apresentaram apenas $\sigma_{\mathrm{RT}}=155,4 \mathrm{MPa}$.

A pressão de compactação foi também decisiva, pois as peças prensadas à 200MPa, tratadas termicamente, usinadas $(f=100 \mathrm{~mm} / \mathrm{min})$ e sinterizadas, alcançaram tensão de ruptura flexão a quatro pontos média de $\sigma_{\mathrm{RT}}=375 \mathrm{MPa}$.

Relativo à velocidade de avanço, usinagem com $\mathrm{f}=200 \mathrm{~mm} / \mathrm{min}$ nas peças prensadas à $100 \mathrm{MPa}$ foi constatada diminuição na resistência à flexão a quatro pontos final das peças, a experimentação com acelerômetro fixado no porta ferramentas não se mostrou conclusiva para explicar este fenômeno relativamente à um evento vibratório atípico, o qual é atribuído para um compromisso destrutivo entre ganho de qualidade superficial com o aumento da taxa de avanço e perda devido ao aumento dos esforços de corte. Entretanto este valor de avanço é particular às condições experimentais adotadas e não pode ser exportado para outros experimentos.

Os blanks prensados a 200MPa e usinados com $\mathrm{f}=400 \mathrm{~mm} / \mathrm{min}$ garantiram uma ótima qualidade de acabamento superficial, e resistência mecânica, onde obteve-se valores médios $\sigma_{\mathrm{RT}}=375 \mathrm{MPa}$ com pico em $400 \mathrm{MPa}$ que está de acordo com a literatura no quesito cerâmicas avançadas, validando a usinagem a verde como um método de fabricação para peças de alto desempenho.

Foi identificada uma correlação entre potência consumida e taxa de remoção, a qual forneceu informações muito importantes para o projeto de uma máquina de usinagem a 
verde de produtos cerâmicos em alumina. Para estas condições experimentais nas peças prensadas a $100 \mathrm{MPa}$ se identificou a taxa de remoção de $8.000 \mathrm{~mm}^{3} / \mathrm{min}$ com potência de pico consumida de $800 \mathrm{~W}$ como a melhor relação de custo/benefício.

Nas condições experimentais aplicadas (equipamento, ferramenta e material) o aumento da taxa de avanço e profundidade de corte pouco afetou a resistência mecânica das peças sinterizadas, contradizendo os preceitos da usinagem, esta observação é atribuída a manutenção da qualidade superficial entre os diferentes avanços, e como o acabamento superficial é decisivo nas propriedades mecânicas das cerâmicas houve a manutenção da resistência mecânica.

Foram manufaturados pinos dentários em gradiente funcional com núcleo denso e superfície gradualmente porosa, sem delaminação. Os pinos dentários em gradiente funcional com $70 \%$ de porosidade na superfície mais externa são aptos a serem recobertos por materiais bioativos para as aplicações desejadas.

O trabalho conceituou um projeto de máquina, que foi validado pelos ensaios de seu protótipo, onde além de gerar um banco de ensaios útil ao grupo de pesquisa, permitiu ao grupo o domínio da tecnologia de projeto do equipamento, mesmo, considerando alguns itens de importação que são plenamente substituíveis pelo grupo.

\section{Sugestões para trabalhos futuros}

Estudo da superfície do rebolo dressado e após a usinagem.

Substituição do atual rebolo por outro que suporte maior velocidade periférica.

Variar a velocidade periférica do rebolo e do blank para determinar um ponto ótimo para usinagem.

Substituir os motores de passo que movimentam a mesa $X Y$ por motores lineares ou servo motores com maior potência e blindagem.

Substituir o sensor de torque por um de maior sensibilidade e tempo de resposta; Integrar todo equipamento em um mesmo compartimento.

Melhorar o sistema de evacuação dos cavacos da usinagem. 


\section{BIBLIOGRAFIA}

ALBARO, J.L.A. A operação de prensagem: considerações técnicas e sua aplicação industrial. Parte V: descrição da etapa de prensagem. Cerâmica Industrial, v.6 (3) Maio/Junho, 2001 p. $26-32$.

ALBARO, J.L.A. A operação de prensagem: considerações técnicas e sua aplicação industrial. Parte I: O preenchimento das cavidades do molde. Cerâmica Industrial, v.5 Setembro/Outubro, 2000 p. 23 - 25.

ALBARO, J.L.A. A operação de prensagem: considerações técnicas e sua aplicação industrial. Parte II: A compactação. Cerâmica Industrial, v.5 Novembro/Dezembro, 2000 p. $14-20$.

ASSOCIAÇÃO NACIONAL DOS FABRICANTES DE CERÂMICA PARA REVESTIMENTO ANFACER. História da Cerâmica. Disponível em: <http://www.anfacer.org.br/principal.aspx?tela=ucTelaConteudos\&idMenu=92>. Acesso em: 22 ago. 2011.

BAILEY, M. W; JUCHEM, H. O. The advantages of CBN grinding: low cutting forces and improved workpiece integrity. Industrial Diamond Review, v.58, n.578, p.83-89, Mar1998.

BANDYOPADHYAY, G, FRENCH, W. K., 1994. Effects of powder characteristics on injection molding and burnout cracking. American ceramic society bulletin, v.73, n.3, March 1994, p.107.

BIANCHI, E. C.; FERNANDES, O. C.; VALARELLI, I. D. D. et al. A contribuição dos rebolos superabrasivos com ligantes resinóide e vitrificado. Máquinas e metais, São Paulo, a.35, n.398, p.88-113, MAR1999.

BRINKSMEIER, E.; ÇINAR, M. Characterization of Dressing Process By Determination of the Collision Number of the Abrasive Grits. Annals of CIRP, v.44/1, p.299-304, 1995.

BUKVIC G; SANCHEZ LEA; Fortulan CA; FIOCCHI AA; Sarni MIJ. Avaliação da usinagem em verde orientada à minimização da distorção e rugosidade de peças sinterizadas. In: $54^{\circ}$ Congresso Brasileiro de Cerâmica, 2010, Foz do Iguaçu. Anais do 54 Congresso Brasileiro de Cerâmica. São Paulo, 2010. 
CALLISTER JUNIOR, W.D. Fundamentos da ciência e engenharia de materiais: uma abordagem integrada. Ed. LTC. 2005.

DORNFELD, D. Application of Acoustic Emission Techniques in Manufacturing. NDT\&E Inst. 25 (6), p.259-269, 1992.

GAMBALE, B.V.V. ; PURQUERIO, B. de M.; FORTULAN, C. A. Green Machining Of High Alumina Electrical Porcelain. In: $52^{\circ}$ Congresso Brasileiro de Cerâmica, 2008, Florianópolis. Anais do $52^{\circ}$ Congresso Brasileiro de Cerâmica. São Paulo : Associação Brasileira de Cerâmica, 2008a.

GAMBALE, B.V.V.; PURQUERIO, B.M.; FORTULAN, C.A. Influence of alumina content in green machined electrical porcelain In: Congresso Brasileiro de Engenharia e Ciência dos Materiais, 2008, Porto de Galinhas. Anais do CBECiMat2008. São Bernardo do Campo-SP: Monferrer Produções 11-4127.6763, 2008b. p.2014 - 2024

GOMES, J. J. F. Identificação em processo de mecanismos de desgaste de rebolos, 2001, Tese (Doutorado em Engenharia Mecânica) - Escola de Engenharia de São Carlos, Universidade de São Paulo, São Carlos.

HEIMKE, G., 1987. Ceramics for osseo-integrated implants. Advanced ceramic materials. v.2, n.4, p.764-770.

KAMBOJ, R. K. DHARA, S.; BHARGAVA, P. Machining behaviour of green gelcast ceramics. Journal of the European Ceramic Society, v.23, p. 1005-1011, 2003.

KAMBOJ, R.K.; DHARA, S.; BHARGAVA P. Machining behaviour green gelcast ceramics. Journal of the European Ceramic Society. v. 23, p. 1005-1011. 2003.

KEVIN WU, X.L.; MCANANY, W.J. Acrylic binders for green machining. American Ceramic Society Bulletin v. 75, p. 61-64. 1995.

KLOCKE, F.; GERENT, O.; SCHIPPERS, C. Machining of advanced ceramics in the green state. Ceramic Forum International, v.74, n6, p.288-290, 1997. 
KÖNIG, W., POPP, M., 1989. Precision machinig of advanced ceramics. American ceramic society bulletin, v.68, n.3, p.550-553.

LAMMER, A., 1990. Ceramics after grinding. Industrial Diamond review, v.50, n.537, p.9498.

LAURENT, P.; DE MELLO, J. D. B., Visualização "in situ" do processo de desgaste abrasivo de materiais cerâmicos. In: XXXV Congresso Brasileiro de Cerâmica e III Iberoamericano de Cerâmica, vidro e refratários. Anais, v.1, p.737-746

LERICHE, A.; MOORTGAT, G.; CAMBIER, F.; HOMERIN, P.; THEVENOT, F.; ORANGE, G.; FANTOZZI, G. Preparation and microstructure of zirconia-toughened alumina ceramics. In: Advances in Ceramics. Science and Technology of Zirconia III. Ed. The American Ceramic Society, Inc., v.24, p.1033-1041, 1988.

MAIER, H.R.; MICHAELI, N. Green Machining of Alumina. Key Engineering Materials. v. 132-136, p. 436-439, 1997.

MALKIN, S., HWANG, T. W., Grinding Mechanisms for Ceramics, Annals of the CIRP, Vol. 45, 1996, pp. 569-580. Revista industrial diamond review vol 60 number 584 (2000) p37 42.

MARTEN, F. L. Vinyl Alcohol Polymers, "Encyclopedia of Polymer Science and Engineering", Mark, H. F., Bikales, N. M., Overberger, C. G., Menges, O., Kroschwjts, J. 1. (eds.), 2ed., John Wiley \& Sons, New York, 1988, vol. 17, p. 167-198.

MASTERS, K., 1994. Applying spray drying to ceramics. American ceramic society bulletin, v.73, n.1, p.63-72.

MAYER Jr, J. E., FANG, G. P., 1994. Effect of grit depth of cut on strength of groud ceramics. Annals of the CIRP, v.43, n.1, p.309-312.

MAYER Jr, J. E., FANG, G. P., 1995. Effect of grinding parameters on surface finish of ground ceramics. Annals of the CIRP, v. 44, n.1, p. 279-282.

NOGUEIRA, R. E. F. Q., 1992. Processing and properties of molded alumina bodies. Tese de doutorado defendida em Brunel University, Inglaterra 
PANDOLFELLI, V.C., BALDO, J.B., CASARINI, J. R., 1981. Influencia dos aditivos, na obtenção de aluminas com alta densidade a verde. Cerâmica, v.27, n.127, p.403-410.

PFEIFFER, W.; HOLLSTEIN, T., Influence of grinding parameters on strength-dominating near-surface characteristics of silicon nitride ceramics. Journal of European Ceramic Society, v.17, p.487-494, 1997.

RAE, A., STEIGER, R., 1994. Green ceramics manufacturing. American ceramic society bulletin, v27, n.127, p.403-410

REED, J.S. Principles of ceramics processing. 2 ed. Ed. John Wiley \& Sons, Inc. USA, 1995.

REGIANI, I. Usinagem abrasiva de cerâmicas avançadas. São Carlos, 1997. 158p. Dissertação (Mestrado) - Escola de Engenharia de São Carlos, Universidade de São Paulo.

RICHERSON, D. W. Modern ceramic engineering: properties, processing and use in design. $2^{\text {nd }}$ edition, Marcel Dekker, Inc. USA, 1992.

SANCHES, L. E. A., Estudo do comportamento da emissão acústica (EA) no ensaio de riscamento em materiais cerâmicos. Tese de Doutorado. EESC. 152p, 1997.

SCHELLER, W.L.I.; WANMUHAMAD, W. Machining of green Si3N4 polymer bonded ceramic materials. Material and Manufacturing Processes. v. 11, n. 5, p. 775-787. 1996.

SHIH, A. J.; GRANT, M. B.; YONUSHONIS, T. M.; MORRIS T. O. MCSPPADEN, S. B. High Speed and High Removal Rate Grinding of Ceramics Using the Vitreous Bond CBN Wheels, 1998, Annual Meeting of American Society for Precision Engineering, p.25-30. Oct. 1998.

SPUR, G., WEIGMANN, U. -P.,1996. Honing of oxide ceramics. Industrial diamond review, v.56, n.570, p.10-16.

SU, B.; DHARA, S.; WANG, L. Green ceramic machining: A top-down approach for the rapid fabrication of complex-shaped ceramis. Journal of the European Ceramic Society 28 (2008) p. 2109-2115. 
SUBRAMANIAN, K., RAMANATH, S., MATSUDA, Y. O., 1990. Precision production grinding of fine ceramics. Industrial diamond review, v.50, n.540, p.254-261.

SUBRAMANIAN, K.,1988. Precision finishing of ceramic components with diamond abrasives. American ceramic society bulletin, v.67, n.6, p.1026-1029.

SUTO, T.; WAIDA, T.; NOGUCHI, H.; INQUE, H. Wheel Designs for Grinding, Industrial Diamond Review, v.50, n.538, p.133-136, Mar.1988.

TAKAGI, J.; LIU, M. Fracture Characteristics of Grain Cutting Edges CBN Wheel in Turning Operation. Journal of Materials Processing Technology, v.62, p.397-402, 1996.

TAWAKOLI, T. Requirements for High-efficiency Deep Grinding, Industrial Diamond Review, v.50, n.539, p.177-182, Apr. 1990.

TING, J. M., LIN, R. Y., 1994. Effect of particle-size distribution on sintering. Part I modeling. Journal of materials science, v.29, p.1867-1872

TING, J. M., LIN, R. Y., 1995. Effect of particle-size distribution on sintering. Part II sintering of alumina. Journal of materials science, v.30, p.2382-2389

TLUSTY, J. Static and dynamic stiffness. In TLUSTY, J. \& KOENIGBERGER, F. Machine tool structures. Oxford Pergamon Press, 1970, v.1, p.519.

TÖNSHOFF, H. K.; FALKENBERG, Y. High-speed grinding of cast iron crankshafts with CBN tools. Industrial Diamond Review, v.56, n. 571, p.115-119, Apr. 1996.

TSUKUDA, A.; KONDO, Y.; KUROSHIMA, Y.; UEMATSU, K., Relationship between grinding mechanism and residual cracks in single point grinding test of alumina ceramics with different grain sizes. Journal of the Ceramic Society of Japan, v.103, n.3, p271-276, 1995.

TUAN, W. H.; KUO, J. C., Effect of abrasive grinding on strength and reliability of alumina. Journal of European Ceramic Society, v.18, p.799-806, 1998. 
UNIVERSIDADE DE SÃO PAULO - USP -. Escola de engenharia de Lorena. Departamento de Engenharia de Materiais. Lorena, c2008. Disponível em: <http://www.demar.eel.usp.br/historicograd.html>. Acesso em: 22 ago. 2011.

UNIVERSIDADE ESTADUAL DE CAMPINAS - UNICAMP - módulo ii : mecânica das rotações, 2011. Disponivel em <http://www.ifi.unicamp.br/ lunazzi/Modulo_II/Modulo_II.htm> Acesso em 25 ago 2011

WARDANY, T.; BARTH, R.; HOLOWCZAK, J.; TREDWAY, W.; CHEN, L.J. Optimum process parameters to produce green ceramic complex parts. CIRP Annals - Manufacturing Technology 58 (2009) p. 109-112.

WARNECKE, G., ROSEMBERGER, U., 1995. Basics of process parameter selection in grindidng of advanced ceramics. Annals of the CIRP, v.44, n.1, p.283-286.

WERNER, G.; TAWAKOLI, T. High efficiency Deep Grinding with CBN. Industrial Diamond Review, v.48, n. 526, p.124-128, Mar. 1988.

WREGE, P.A.S.; PURQUERIO,B.M. Metodologia para obtenção de esferas de cerâmica para próteses de quadril. São Carlos, 2000 - Tese doutorado - Escola de Engenharia de São Carlos, Universidade de São Paulo.

WREGE, P.A.S.; FORTULAN, C.A.; PURQUERIO, B.M.; RIBEIRO, F.M.M. Opção eficiente para estruturas de máquinas de precisão. Máquinas e Metais, n. 397, p.61-69, 1999.

WU, X. L. K., W. J. McANANY, 1995. Acrilyc binder for green machining. American ceramic society bulletin, v.74, n.5, May 1995, p.61-64.

XU, H. H. K., HAJANMIR, S., 1994. Simple technique for observing subsurface damage in machining of ceramics. Journal of American ceramic society, v.77, n.5, p.1388-1390.

XU, H. H. K., JAHANMIR, S., 1996. Transitions in the mechanism of material removal in abrasive wear of alumina. Wear, n.192, p.228-232.

YUI, A.; LEE, H. Surface Grinding with Ultra High Speed CBN Wheel. Journal of Material Processing Technology, v.62, p.393-396, 1996. 
ZIPSE, H. Finite-element simulation of the die pressing and sintering of a ceramic component. Journal of the European Ceramic Society, v.17, p.1707-1713, 1997.

ZORZI, J. E., da JORNADA, J. A. H., MODESTO, F., WEINGAERTNER, W. L., 1995. I Seminário de tecnologia cerâmica, IV Feira de tecnologia cerâmica do Colégio Maximiliano Gaidzinski. Cocal do Sul, Santa Catarina. 